Historic, Archive Document

Do not assume content reflects current scientific knowledge, policies, or practices. 

6209
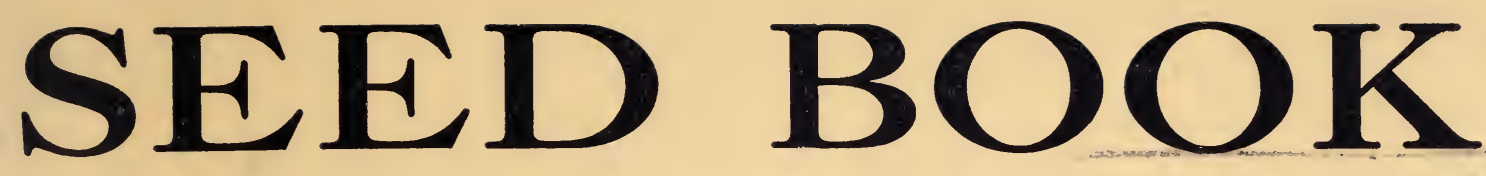

$\begin{array}{llll}1 & 9 & 3 & 1\end{array}$

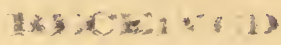

- JAN $311931+$

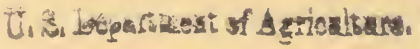

OF

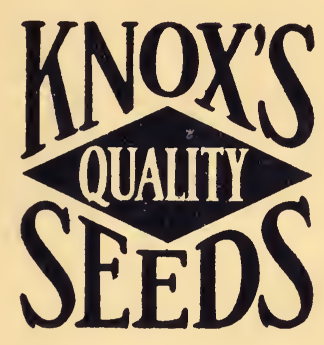

Knox Seed Company

509-511 E. Weber Ave.

STOCKTON, CALIFORNIA

Vegetable Seed Trials 
YOUR NAME AND ADDRESS. Be very sure that your name and address are written plainly on each order. We frequently have orders where either name is not given or address omitted. Also give plainly the R. F. D. number and box, or the street plainly the R. F. D. number and box, or the street if not filled immediately. If such acknowledgement is not received, or if the order does not follow at once, write us about it.

CASH WITH ORDER.. The proper way is to send remittance in full to cover order and postage. We send Seed and Poultry supplies C. O. D. Plants we never send out C. O. D. (There is an extra charge of $12 \mathrm{c}$ on C. O. D's)

ALL PRICES are subject to price fluctuation and to change without notice. For this reason we ask you to write for quantity price. On vegetable seeds the price is usually fixed for the season and rarely is it necessary to change from the catalog, and the prices will be consistent with the market. You will be treated fairly.

REMITTANCES should be made by Post Office Money Order, Express Money Order, or by Check. For amounts up to one dollar, clean, unused post- age stamps will be accepted. Coin should not be sent by mail. Checks on local banks may be sent, which will be a great convenience to many customers. WV do not accept responsibility for orders which never reach us.

SHIPPING. We will use our best judgment as to the best way of sending orders when specific directions are not given. In large "prepaid" orders it is better to have them go by express, if your town is on a railroad-it is safer. "We prepay express charges on merchandise quoted "prepaid." If special directions in shipping are needed, send them explicitly, and where express or freight office is different from post office, so state in space on our order sheet.

SEEDS BY MAIL. We send by mail or by express prepaid, all orders for flower seeds, and for vegetable seeds up to ten pounds. We do not pay postage or express charges on onion sets, field seeds, clovers, grasses, bird seeds, tools or plants in large quantities; but we pay them on other vegetable and flower seeds. Correspondents in foreign countries should add a sufficient amount for postage at the rate of 14 cents per pound.

\section{DOMESTIC PARCEL POST RATES}

DOMESTIC PARCEL POST RATES
Our Seeds, Plants, Bulbs, Roots, Books, Tools, age up to $\$ 5.00$, 3c for each Packetc., within the U. S. and Possessions. $10 \mathrm{c}$ up to $\$ 50.00$.
First Pound or Fraction
Each Add. Pound or Fraction

First Zone, Stockton and within 50 miles of Stockton. Second Zone within 50 to 150 miles of Stockton. Third Zone within 150 to 300 miles of Stockton. Fourth Zone within 300 to 600 miles of Stockton. Fifth Zone within 600 to 1000 miles of Stockton... Sixth Zone within 1000 to 1400 miles of Stockton... Seventh Zone within 1400 to 1800 miles of Stockton Eighth Zone within all over 1800 miles from Stockton.

$\begin{array}{rr}7 \mathrm{c} & 1 \mathrm{c} \\ 7 \mathrm{c} & 1 \mathrm{c} \\ 8 \mathrm{c} & 2 \mathrm{c} \\ 9 \mathrm{c} & 4 \mathrm{c} \\ 10 \mathrm{c} & 6 \mathrm{c} \\ 11 \mathrm{c} & 8 \mathrm{c} \\ 13 \mathrm{c} & 10 \mathrm{c} \\ 14 \mathrm{c} & 12 \mathrm{c}\end{array}$

FOR PARCELS WEIGHING 8 OUNCES OR LESS, containing seeds, bulbs or books only the rate of postage to all zones is 1 cent for two ounces or fraction. (Over 8 ounces the parcel post rates apply).

NON-WARRANTY: Note-There are so many contingencies to be encountered in growing plants from seed and in setting out plants that are dependent on the weather and other conditions over which we have no control, that success in planting is not altogether dependent on the seed or plant. We will send out only seed which we be- lieve will grow and produce the kind of plant and variety represented, but:

KNOX SEED CO., Inc., give no warranty, express or implied, as to description, quality, productiveness, or any other matter of any seeds, bulbs, plants or trees they send out, and they will not be responsible in any way for the crop. If the purchaser does not accept the goods on these terms, they are at once to be returned and money will be refunded.

KNOX SEED CO., Inc.

JAMES KNOX, President and Manager.

\section{ALPHABETICAL INDEX FOR KNOX SEED CO. 1931 SEED CATALOG}

\section{VEGETABIE SEED}

Artichoke

Asparagus Seed

Asparagus Roots

Beans

Beets, Tábie

Beets, Stock

Borecole or $\dot{\mathrm{K}} \overrightarrow{\mathrm{ale}}$

Brussels Sprouts

Broccoli

Cabbage

Cantaloupe or Muskmelon... 17

Carrots ...................... 10

Casaba Mejons

Cauliflower

Celery

Celeriac

Chicory

Corn, Sweet or Sugar.

Cucumbers

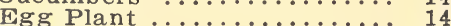

Garlic

Kale

Kohl Rabi

Leek

Lettuce

Mangel Wurzels
Mushroom Spawn

$\ldots \ldots \ldots 15$

Muskmelons $\ldots \ldots \ldots \ldots \ldots \ldots \ldots 1$

Okra or Gumbo............ 15

Onions

Onion sets $\ldots \ldots \ldots \ldots \ldots \ldots \ldots$.

Oyster Plant .............. 20

Parsley ................ 22

Parsnips

Peas

Peppers

Pop Corn

Pumpkins

Radishes

Rutabaga

Salsify ............... 20

Spinach ............... 24

squash

Swiss Chärd

Tomatoes

Turnips

Watermelons

FIELD SEED

Alfalfa Seed

Beets, Stock

Beets, Sugar

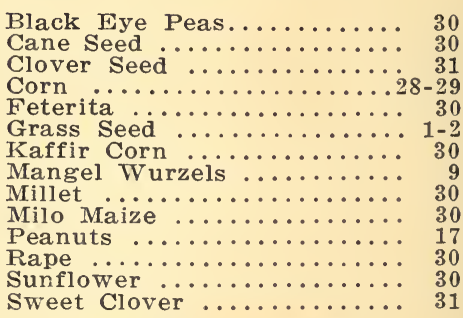

FLOWER SEEDS

Pages 33 to 50 inclusive

MISCELLANEOUS

Bird Supplies .......... 56

Dusters $\ldots \ldots \ldots \ldots \ldots \ldots \ldots \ldots . \ldots \ldots$

Herb Seeds ................. 15

Insecticides $\ldots \ldots \ldots \ldots \ldots \ldots .51-52-56$

Seed Sowers ............ 31

Spraying Suggestions 26-32-50-56

Sprayers......Inside Back Cover

Gopher Gun................ 20

Poultry Remedies ....... $53-54-55$ 


\title{
Knox's Lawn Grass Seed
}

\author{
PRODUCES A RICH, THICK, VELVETY LAWN
}

\section{A Beautiful Lawn and How to Secure It}

It is universally conceded that nothing contributes so much to the beauty and attractiveness of the home grounds, the park and the cemetery, as a smooth, uniformly rich-green, well-kept lawn. But to be perfect and a pleasure to walk on this should have a firm yet elastic and carpet-like surface, and the first consideration in laying out sulface, and the first consideration in laying out
or renovating old grounds should be to secure this condition.

Turfing with fine old pasture sod, at one time a popular method of making a lawn, is now largely superseded by seeding, because of the expense and difficulty in obtaining good, clean turf. Seeding is not only inexpensive but is in reality the only means of securing a fine and permanent lawn. dependillg only for its complete success on the thoroughness with which the ground is prepared, the quality and quantity of the seed sown, and the subsequent care of the lawn.

Our extensive experience in the seeding of lawns and exhaustive experiments with all kinds of lawn grasses have demonstrated beyond a doubt that while many kinds are valueless, being too coarse or bunchy or otherwise unsuitable, one kind of grass alone can not be relied upon, in our climate, to produce and maintain a fine lawn. It is only by using a proper combination of several suitable varieties, sown liberally, that satisfactory results can be obtained.

KNOX'S LAWN GRASS MIXTURES are the result of years of study and careful observation, and, if our directions are followed in seeding, they never fail to produce quickly a thrifty growth of fine velvety, rich green grass, continuous in verdure from early spring to winter, and creating a springy, dense, carpet-like turf and permanently beautiful lawn.

THE QUANTITY OF SEED REQUIRED-There is no fixed rule, but a liberal sowing is always satisfactory, while a light seeding is a waste of time and usually disappointing. A beautiful lawn may be produced in a few weeks, or it may not approach perfection for two or more seasons, according to the quantity of seed sown. One pound to 200 square feet; 5 pounds to 1,500 square feet; 20 pounds to 6,000 square feet; 100 pounds (5 bushels) per acre.

In thickening up established lawns slightly smaller quantities, depending on conditions, may perhaps be sufficient, but it is always well to put on enough.

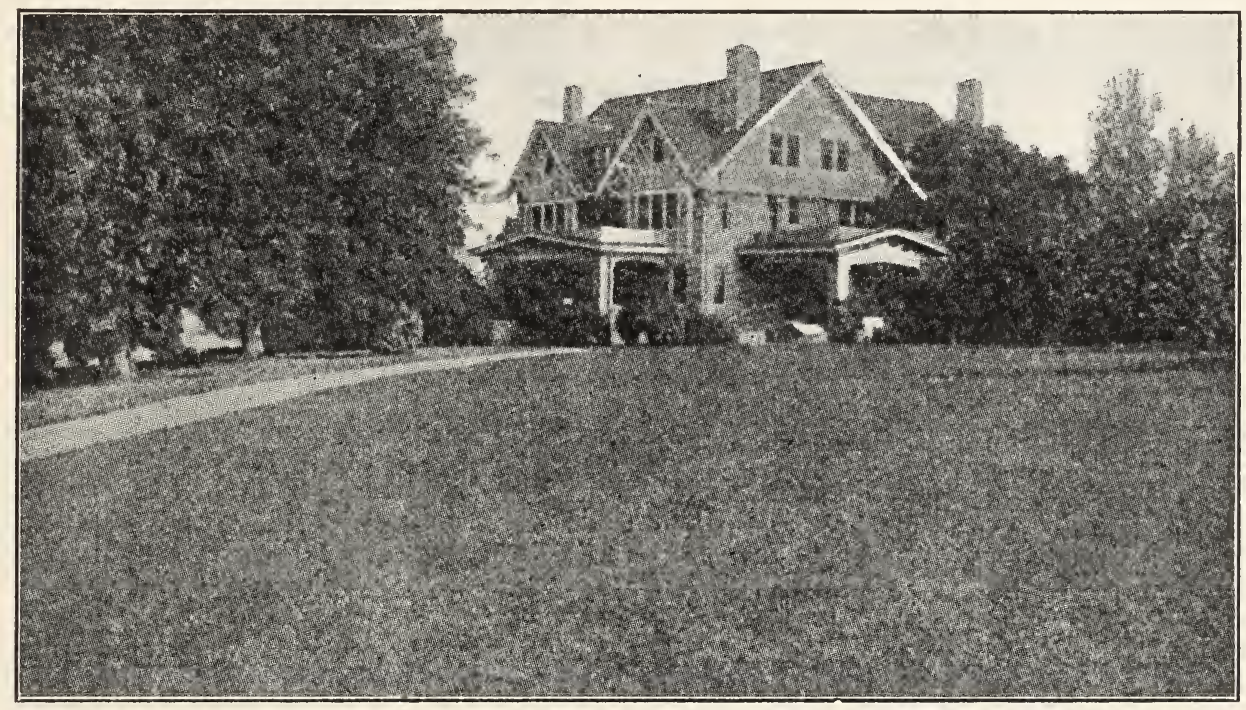

\section{THOROUGHLY TESTED AND ANALYZED FOR GERMINATION AND PURITY}

\footnotetext{
Composed of Evergreen Grasses, best suited to our American Climate, only the finest and eleanest grades of Seed being used. This splendid mixture is composed of only the finest dwarf-growing evergreen grasses; absolutely free from weed seeds or other impurities; especially adapted and mixed in the proper proportions to suit the American climate. In comparing the cost of our Special Lawn Grass with other mixtures sent out by the trade, remember that the actual weight per measured bushel of our mixture is 20 pounds or more, while that of most mixtures is only i4 pounds per bushel. To obtain this exceptionally heavy weight per bushel, we must and do use only the heaviest and best samples tain this exceptionally heavy weight per bushel, we must and do use only the heaviest and best samples seens as the heavier the mixture the more thoroughly recleaned have been the component grasses, $1 / 2$ lb. 35e (by mail 42c); 1 lb., 70e (by mail 77 e); 10 lbs. \$6.50.
}

WHITF CLOVER-Extra choice, thoroughly recleaned seed suitable for fine lawns. $1 / 4$ lb., 20 (by mail 27e); 1/2 lb., 30c (by mail 37e); 1 lb., 60e; (by mail, 67e. Subject to market changes.

If more than one pound is wanted by mail, add postage at Parcel Post rates. 


\section{Knox's Lawn Grass Seeds}

KNOX'S GRASS MIXTURE FOR SHADE-The growing and maintaining of a nice fresh green Sward or Turf below trees or in shady places has long been regarded as a matter of great difficulty. In our Grass Mixture for shade we have an excelient combination of those grasses which grow naturally in shady places and under any ordinary circumstances will furnish a close, green, velvety turf during the entire season. However, it is often the case that under trees the ground becomes so impoverished by the action of the multitude of fine tree roots as to render the growing of a nice, close sod of grass almost impossible; in such cases we would recommend a liberal top dressing of Mococo Wertilizer at the rate of 600 pounds per acre.

Price: 1/2 lb. 60e (by mail 67e); 1 lb. \$1.00 (by mail \$1.07); $21 / 2$ 1bs. \$2.25; 5 lbs. \$4.25; 10 Ibs. \$8.00.

GOLF LINKS MIXTURE FOR PUTTING GREEN -The grasses composing this mixture are those which years of experience have shown to be the best adapted to the uses of the Putting Green. They are dwarf-growing and compact, yet hardy enough to withstand the constant, heavy wear of the Putting Green. Price: 1/2 lb. 35e (by mail 42c); 1 lb., 60c (by mail 67e); $21 / 2$ lbs. $\$ 1.45 ; 5$ lbs. $\$ 2.75 ; 10$ lbs. \$5.25; 20 lbs. \$10.25; 50 1bs. \$25.00; 100 lbs \$48.00.

GOLF LINKS COURSE MIXTURE FOR FAIR GREENS-A mixture of grasses that will stand the wear incidental to the game of golf or other outdoor sports, forming a nice, close turf that will hold out even in the dry part of our American summer. Hrice: 1/2 1b. 25e (by mail 32e); 1 1b. 45e (by nuil 52e): $21 / 2$ lbs. \$1.05; 5 lbs. \$2.00; 10 lbs. \$3.85; 20 lbs. \$7.50; 50 Ibs. \$18.00; 100 lbs, \$35.00.

\section{KENTUCKY BLUE GRASS}

The universal pasture grass of America and the finest lawn grass in the world is our own Kentucky Blue Grass. It starts like magic with the first smile of spring and is a velvet of green until winter comes again. It can be sown on the wild prairie and will catch, but the best results are to be had by getting the seed well covered. The seed we offer is strictlv high grade, new crop, clean and pure. 75e per lb.; 10 lbs., \$7.00; prepaid.

BERMUDA GRASS-Good for both pasture and hay and especially adapted for the South where other grasses will not grow. A perennial or low, creeping habit. Sow 6 pounds to the acre. Lb.,

ITALIAN RYE GRASS-Thrives on almost any good soil and is unequalled for producing an abundance of feed early in the spring as well as throughout the season. Responds quickly to rich food and moisture and is a rapid grower. Sow 50 lins to the acre. Lb.. 25c.
MEADOW FESCUE - One of the finest annual grasses for permanent pastures, highly nutritious and relished by stock. Succeeds well in all soils but best on moist land. Robust in habit and grows over a long season. Sow 60 to $70 \mathrm{Jbs}$. to the acre Lb., 45c.

\section{AUSTRALIAN or PERENNIAL RYE GRASS}

This grass has become exceedingly popular of late years: it makes a very hardy and beautiful bright green lawn, and if properly cared for, a very satisfactory one. It does particularly well in sandy lots. Valuable as a pasture grass. Sow about two busliels per acre. 25e per lb.; 10 lbs., \$2.00.

PACIFIC RYE GRASS-This is a fine grass for quick lawns or lawn mixtures. Also valuable for forage plants. Lb., $\mathbf{2 5 c}$

CHEWING FESCUE (Festuca Duriuscala)-This is a variety of hard fescue and is used by golf cluhs in their mixtures. It is also a good pasture grass makes good turf. Lb. 65c.

CREEPING BENT GRASS-(Agrostis Stolonifera) -The texture of this grass is fine and is valuable for lawns, grows rapidly and is of the spreading habit, makes good turf. Lb., \$1.50.

CRESTED DOG'S TAII, (Cynosurus Cristatus)-It does well in shady places, it roots deeply and makes a good lawn mixture and should be used in moderate quantities for permanent pasture. Lb. 65e.

RED-TOP, FANCY-This grass is used for mixing in hay or permanent pasture and succeeds almost everywhere, but does best in a moist, rich soil $w^{\circ}$ here it attains a height of 2 to $21 / 2$ feet. We nffer onlv the best quality of recleaned seeds, free from chaff. Sow 32 pounds to the acre. Lb., 40e.

\section{Names of Vegetables in Foreign Languages}

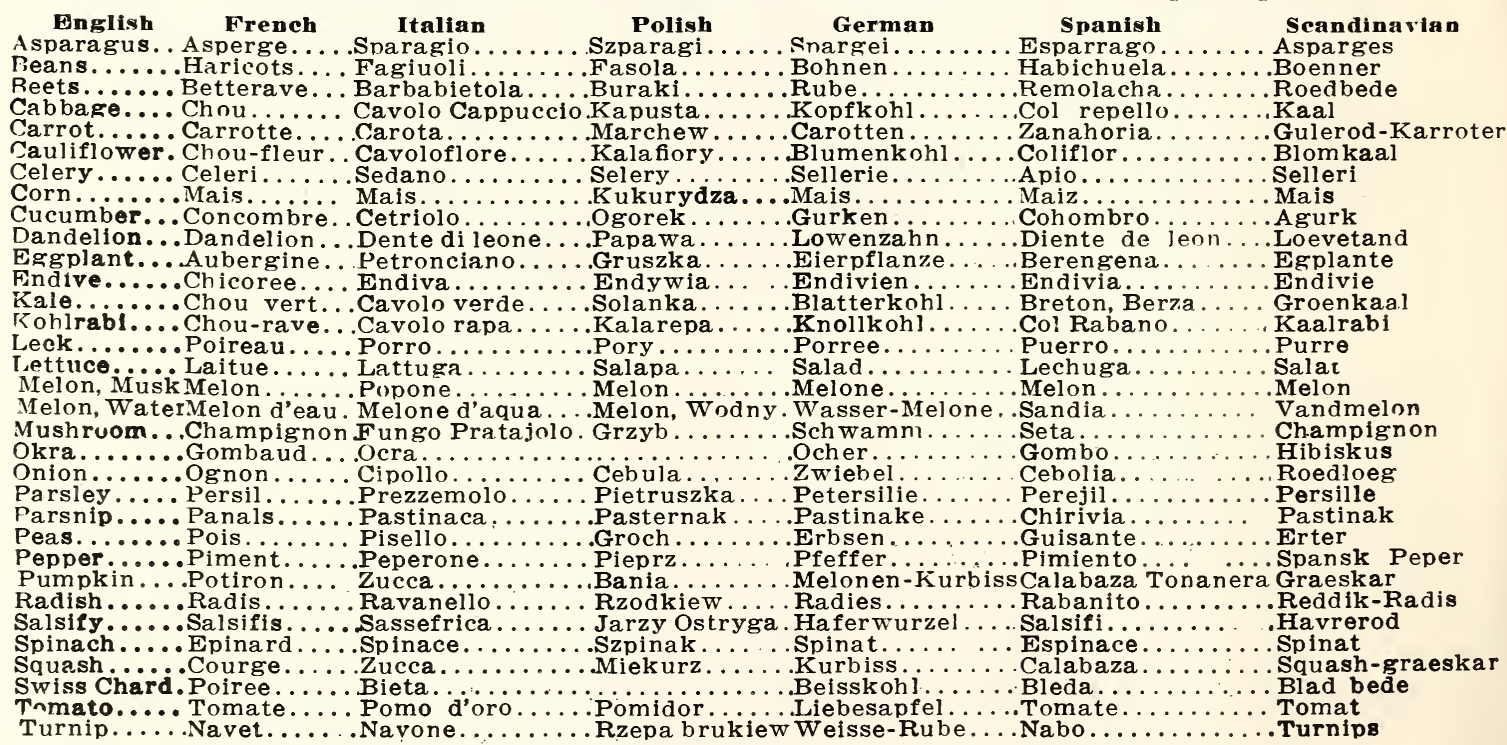




\section{Monthly Planting Guide}

\section{JANUARY}

VEGETABLES-Seeds of Asparagus, Beets, Brussel Sprouts, Cabbage, Carrots, Chicory, Corn Salad, Cress, Egg Plant, Kale, Kohl Rabi, Lettuce, Mustard, Onions, Parsley, Peas, Peppers, Potatoes, Radish, Rhubarb, Salsify, Spinach, (Winter) Tomatoes, Turnips.

FLOWERS-Sow seeds of hardy annuals in the open ground, Acroclinium, Alyssuni, Antirrhinum Calendula, Calliopsis, Candytuft Centaurea, Annual Chrysanthemums, Clarkia, Larkspur, Lupin, Mignonette, Nigella, Poppies, California Poppy, Wild Flower Seed and Sweet Peas.

\section{FEBRUARY}

EGETARLE-Seeds of Asparagus, Beets, Beans, Ca Crn glant, Horse Radish, Kale, Kohl Rabi, Lettuce, Mustard, Onions, Parsnip, Peas, Peppers, Potatoes, Sweet Potatoes, Squash Radish, Rhurbarb, Salsify, Spinach, (Summer) Tomatoes, Turnips.

FLOVERS-Sow Seeds in open ground: Acroclinnium, Antirrhinum, Caledula, Calliopsis, Centaurea, Early Flowering Cosinos California Poppy, LarkEarly Flowering Cosinos, California Poppy, Lark gelia, Poppies, Scabiosa and Sweet Peas.

gelia, Poppies, Scabiosa and Sweet Peas, Coreopsis, Gaillardia, Hollyhock. Hunnemannia, Lobelia, Mimulus, Pentstemon, Petunia, Perennial Poppies, Salvi Stocks and Viola Cornuta.

\section{MARCH}

VEGETABLS-Seeds of Artichoke, Asparagus Beets Beans Cabbare Chicory Corn, (Sweet and Field) Cucumbers, Ege plant, Kale Let tuce, Melons, Field) Cucumbers, Egg Plant, Kale, Lettuce, Melons, (Musk and Water) Okra, Onions. Parsley, Parsnip, barb Seed, Salsify, Spinach, (Summer) Squashes. Tomatoes.

FLOWERS-Sow seeds in open ground; Acroclinum, Ageratum, Alyssum, Antirrhinium, Arctotis, Amaranthus Balsm, Brachycome, Bartonia Calendula Calliopsis Candytuft, Centaurea, Clarkia, Annual Chrysanthemum, Early Flowering Cosmos, Daisies, Four O'Clocks, Godetia, Gomphrena, Gypsophila, Helichrysum, Larkspur, Linum, Lupin, Marigold, Migonette, Nasturtium, Nemesia, Nemophila Nigella, Phlox, Poppy, Scabiosa, Sunflower and Sweet Peas.

Sow in seed boxes or with some protection for transplanting later: Asters, Begonir, Bellis, Daisy, Celosia, Columbine, Canterbury Bells, Coreopsis, Cyclamen, Dahlia, Gaillardia, Gerbera, Heliotrope, Hunnemannia, Lobelia. Matricaria, Mysotis, Pentstemon, Petunia. Poppies, Salvi, Shasti Daisy, Statice, Sweet William, Verbena, Viola, Wallflower, Zinnia. Sow seeds of Vines.

\section{APRIL}

VEGETABLES-Seeds of Artichoke Seed, Aspararus Beets Beans Carrots Cabbage Celery Corn. (Sweet and Field) Cress, Egg Plant, Kale, Lettuce, Melons, (Musk, Water, and Casahas) Okra, Onions, Parsley, Peas, Peppers. Parsnip, Potatoes. Sweet Potatoes. Pumpkin, Radish, Rhubarb Seed, Salsify, Spinach (Summer) Squash, Tomatoes.

FLOWERS-Seeds of Abronia, Acroclinum, Ageratum Antirrhinium Ameranthus Asters, Balsam Aquilegia Begonia, Bellis Brachycome, Calendula, Calliopsis, Candvtuft. Canterbury Bells, Carnation, Annual Chrvsanthemum. Celosia, Cantaurea Clarkia Coreopsis, Cosmos, Cvclamen. Dahlia. Daisies, Delnhinium, Digitalis, Dianthus, Gaillardia, Godetia Gerhera, Gvpsophila, Gomphrena, Heliotrope. Helichrysum. Hunnemannia. Hollyhock, Larksmnur. Lnhelia Linum. Lupin, Marigold, Myosntis Mirahilis, Mimulus. Mignonette. Nasturtium, Nemesia, Nicotiana, Nigella, Pentstemnn. Petunia, Fhlox, Poppies, Portulara. Salva. Salpiglosis. Scabiosa, Schizanthus, Stevia. Stocks, Statice. Sweet William, Vervena, Viola, Sunflower, Wallflower, Zinnia.

\section{MAY}

VEGETABLES-Seeds of Artichoke. Asparagus, Beets, Beans, Cabbae Carrots, Celery Plants. Corn. Beets, Beans, Cabbage, Carrots, elery Plant, Lettuce. Melons (Musk. Water, and Casahas) Okra, Onions, Parslev. Parsnin, Peas, Penners. Transplant Potatoes. Sweet Potatoes (Plants) Pumpkin, Radish. Rhuharb. Salsify, Spinach, (Summer) Squash, Tomatn.

FI, WVERS-Seeds of Abronia. Acrorlinium. Ageratum. Amaranthus, Asters, Balsam. Carnation, Calendula Celosia Centaurea, Calliopsis, Cosmos, Daisles, Annul Chrysanthemum. Candytuft. Dianthus, Gail mannia, Inbelia, Larkspur, Marigold, Matricaria ladia, Gomphrena, Gypsophila, Helichrysum, Hunne-
Nasturtium, Nemesia, Nicotiana Nigella, Phlox, $\mathrm{Pe}$ tunia, Portulaca, Salvia, Salpiglossis, Scabiosa, Schizanthus, Stevia, Sunflower, Statice, Zinnia.

\section{JUNE AND JULY}

VEGETABLES-Seeds of Artichoke, Beets, Beans Cabbage Carrots, Celery Plants, Corn (Sweet and Field) Cucumber, Egg Plant, Lettuce, Melons, (Musk, Water and Casabas) Okra, Parsley, Parsnip, Peas, Pepper, Plants, Potatoes, Sweet Potatoes, (Plants) Pumpkin, Radlsh, Spinach, (Summer) Tomato.

FIowERS-Seeds of Calendula, Candytuft, Cosmos, Centaurea, Cineraria, Daisies, Marigold, Nasturtium, Portulaca, Poppies, Salpiglossis, Zinnia.

\section{AUGUST}

VEGETABLES - Artichoke, Beets, Beans, early varieties, Brussel Sprouts, Cabbage, Cauliflower, Carrots, Chicory, Corn, Cress, Cucumber, Egg Plant, Endive, Garlic, Kale, Kohl Rabi, Leek, Lettuce, Mustard, Onion, Parsley, Parsnip, Peas, Potatoes, Radish, Salsify, Spinach (Summer) Turnips.

FLowers-Calendila, Cineraria, Centaurea, Cosmos, Pansies, Primula, Stocks, Sweet Peas. Begin sowing seeds of hardy perennials for next year's flowering, such as Aquilegia, Bellis, Daisy, Canterbury, Bells, Coreopsis, Cyclamen, Delphinium, Pentstemon, Perennial Poppies, Phlox, Pyrenthrum, Snapdragons, Verbena, Viola and Wallflower.

\section{SEPTEMBER}

VEGETABLES-Seeds of Artichoke, Beets, Brus sel Sprouts, Cabbage, Carrots, Cauliflower, Chicory Cress, Cucumber, Endive, Garlic, Kale, Kohl Rabi, Peas, Potatoes, Radish, Salsify, Spinach, (Winter)

FLOWERs-Seeds of Calendula, Centaurea, Cineraria, African Daisy, Nemesis, Cosmos, Pansy, Primula, Stocks and Winter Sweet Peas. Continu sowing hardy perennials for next year's flowering. such as Aquilegia, Bellis Daisy, Canterbury Bells Coreopsis, Cyclamen, Delphinium, Digitalis, Forgetme-not, Gaillardia, Hollyhocks, Pentstemon, Perennial Poppies, Phlox, Pyrethrum Snapdragon, Verbena, Viola, and Wallflower.

\section{OCTOBER}

VEGETABLES-Seeds of Beets, Brussel Sprouts, Cabbage, Carrots, Chicory, Cress, Endive, Garlic Kale Kohl Rabi, Leek, Lettuce, Mustard Onions, Parsley, Parsnip, Peas, Radish, Salsify Spinach,

FLOWERS - Continue sowing seeds for winter blooming of Calendula, Centaurea, Cineraria, Cos mos, African Daisy, Dianthus, Nemesis, Phlox, Pansy, Primula, Scabiosa, Stocks and Winter Sweet Peas.

Begin sowing annuals in open ground for early spring blooming, Acroclinium, Alyssum, Antirrhi num, Bartonia, Candytuft Caliopsis, Clarkia An nual Chrvsanthemums, California Poppy Larkspur Lupin, Mignonette, Nigella, Poppies, California Wild Flowers, Continue sowing perennials for next year's flowering-Aquilegia, Bellis, Canterbury, Bells, Coreopsis, Cyclamen, Delphinium, Digitalis, Forgetme-not, Gaillardia, Hollyhocks, Pentstemon Perennial Poppies and Phlox, Pyrenthrum, Snapdragon Verbena, viola, and Walleiower.

\section{NOVEMBER}

VEGETABLES-Seeds of Beets, Brussel Sprouts, Cabbage, Carrots, Chicory, Cress, Garlic, Kale, Koh Rabi, Lettuce. Leek, Mustard, Onions Parsley Peas. Radish, Salsify, Spinach (Winter) Turnips.

FLOWERS-Seeds of hardy annuals, Acroclinium, Alyssum Antirrhinium, Bartonia, Calendula Candytuft, Calliopsis, Clarkia, Annual Chrysanthemums, California Poppy, Dianthus, Larkspur, Lupin, Mignonette, Nigella, Nemesia, Pansy, Phlox, Stocks, Winter Sweet Peas and California Wild Flowers.

\section{DECEMBER}

VEGETABLES - Artichoke Plants, Asparagus Roots, Seeds of Beets, Brussel Sprouts Cabbage, Chicory Cress, Endive, Garlic Horse Radish Kale, Kohl Rabi, Leek, Lettuce, Mustard, Onions, Parsley, Parsnips, Peas, Potatoes, Radish, Rhubarb Roots, Salsify Spinach (Winter) Turnips, Onion sets.

FLOWERS-Sow seeds of hardy annuals, Acroclinium, Alyssum, Antirrhinium, Bartonia, Calendula, Candytuft, Calliopsis, Clarkia, Annual Chrysanthemums, California Poppy Dianthus, Larkspur, Lupin. Mignonette, Nigella, Nemesia, Pansy, Phlox. Stocks. Winter Sweet Peas and Callfornla Wild Flowers. 


\section{Knox's Planting Guide}

\section{COMPLETE INFORMATION IN A SIMPLIFIED FORM}

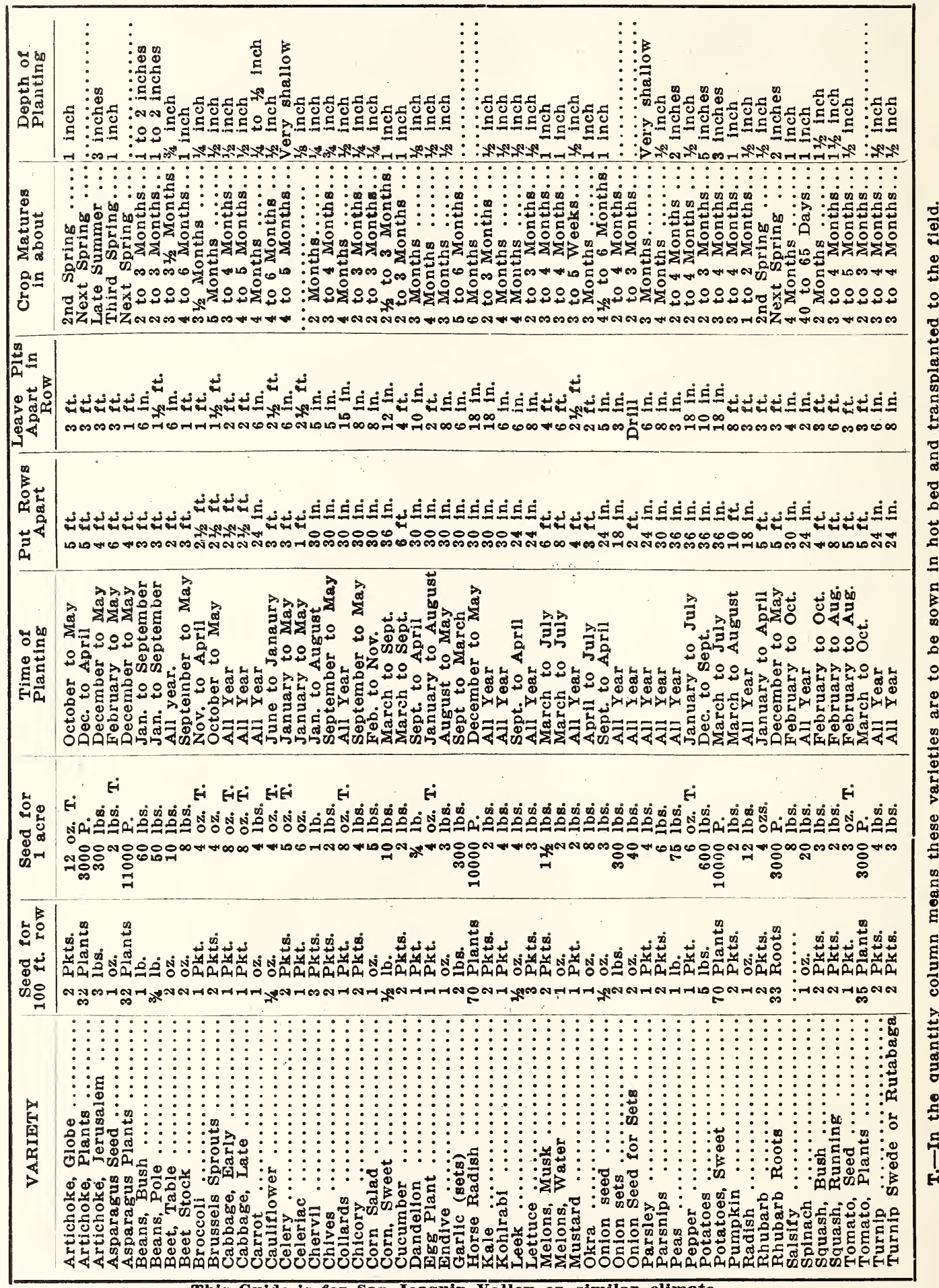

This Guide is for San Joaquin Valley or similar elimate. 


\section{Vegetable Seeds}

in making up this catalog we have endeavored to limit the varieties to those that have proven themselves in this locality. In doing this we have omitted many novelties and unproven varieties. We know that experiments are costly and will assist any of our friends in making the proper selections for their territory.

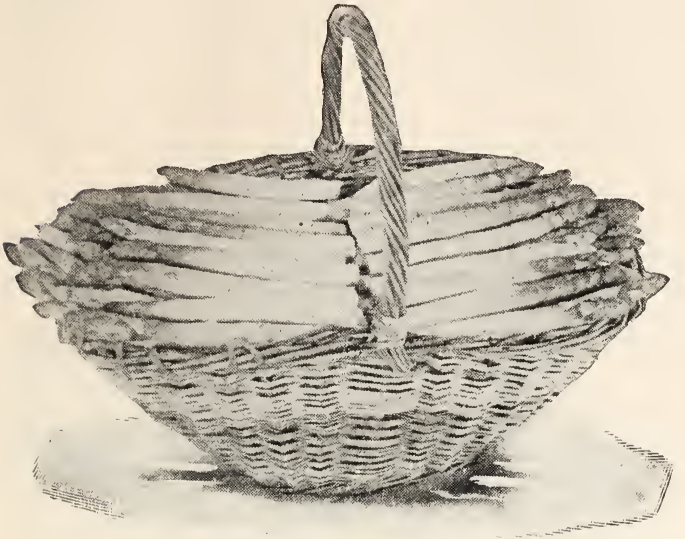

Palametto Asparagus

\section{ASPARAGUS}

One of the most delicious of all vegetables, and the earliest to be taken from the garden. Every garden, large or small, should have a bed of asparagus. A bed properly planted and cared for should last 8 or 10 years and 50 roots should supply the average family.

Plant seeds, preferably in a sandy loam, well mixed with stable manure. Rows should be from 3 to 6 feet apart and slightly below the surrounding ground. Cover seeds 1 to 2 inches. Sow thinly. One packet of seeds will sow about 20 feet of row and yield over 100 plants. If roots are planted. make trenches 18 inches deep and 3 to 6 feet a part and work in plenty of well-rotted manure or lea: mould or both. Set plants 12 to 16 inches apart in the trench and crowns 12 inches below the surface. Each fall top dress with a heavy coat of manure and work it into the soil in the spring. Keep the earth soft and loose over the crowns of the plants. The young shoots may be cut freely up to the green pea season and then left to grow. In the fall cut all the stalks close to the ground before applying the manure. Our asparagus roots are all strong, vigorous stock which will give quick results.

WASHINGTON ASPARAGUS SEED-This asparagus which has been selected by the United States Department of Agriculture has proven to be nearly rust free The shoots are thick and heavy. They are long and straight, with closely folded tips. The color is rich, dark green, tinted darker at the tips. Pkt., 10e; oz., 15e; $1 / 4$ lb., 40e; 1 b., $\$ 1.50$; postpaid.

PALME'I'T - This popular sort is one of the earliest and is an extremely uniform strain, pro. ducing finely flavored large stalks nearly an inch in diameter hut tender and delicious. Pkt., 10e; oz., 15e; $1 / 4$ lb., 35e; 1 b., \$1.25.

ASPARAGUS ROOTS.-Peady in January. Twoyear-old roots, 25e ner doz., \$1.50 per 100; special price for 1,000. Postage $15 \mathrm{c}$ per doz., $50 \mathrm{c}$ per 800 .

\section{BROCCOLI}

Sow seed in May: transplant in June. Growth and habit like cauliflower, but far more hardy. Of special value in the North. One ounce produces 2,500 plants.

ST, VALENTINE-The standard market variety for March shipment. Large plants with dark green waved leaves. Heads are large, solid, white, and very well protected. Pkt., 15e; oz., \$1.50; 1/4 1b., $\$ 4.00 ; 1 b .915 .00$

Dont' wait until your garden is covered with weeds before hoeing. If soil is kept in the proper state of cultivation there will be no weeds to consider.

\section{ARTICHOKES}

The best way to get a good artichoke is to secure plants from old stalks of some good strain, as seeds cannot be depended upon to produce any certain variety. One-half dozen is enough for a family garden.

Transplant five feet apart in rows seven feet apart. When the young plants are attacked by aphis spray with "Black Leaf 40." About the time the buds are well advanced the under leaves become a harbor for flies and aphis and ants. When this occurs break off all the under leaves, clear the ground of all rubbish and spray with "Black Leaf 40 " and use ant poison. See Insecticide page. You will then have a long season of large, clean buds.

IMPROVED LARGE GREEN GLOBE-Produces large, globular heads, thick, succulent scales, the bottom of which is the edible part. Boiled till tender, it makes a delicious dish. Pkt., 10c.

AR'TICHOKE ROO'TS-Artichoke roots when one year old will produce an abundance of large delicious artichokes soon after transplanting. They ar ready in. January and can be planted as late as May. Save a year by planting vigorous roots a year or more old. \$1.00 per doz; 10e ench. Postage 2c each.

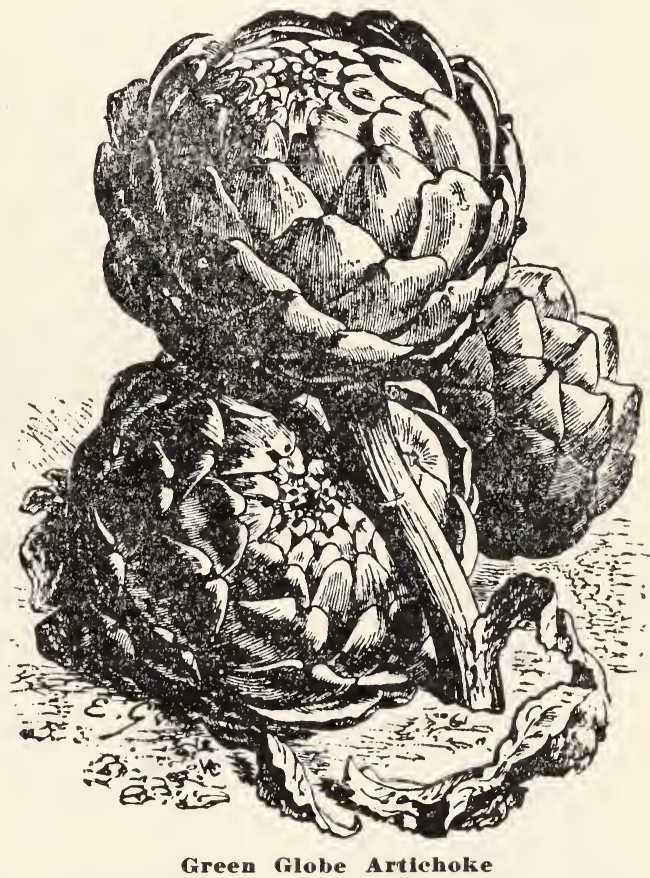

\section{BRUSSELS SPROUTS}

One ounce will produce 1,500 plants.

Plant and cultivate same as Cabbage.

DWAIRF IMPROVED-The stem of this variety grows from 20 to $2 \delta$ inches, closely set with medium-sized grayish green, very firm and well-rounded sprouts. Pkt., 10e; oz., 20c; 1/4 lb., 60e; lb. \$2.00. 


\section{BEANS--Dwarf or Bush}

One pound will sow 100 feet of drill; 40 pounds are required for an acre.

No crop responds more readily than Beans to good soil and cultivation. A light, rich, well drained loam which was manured for the previous crop is the most desirable. If too rank manure is used it 19 apt to make the plant run too much to vine.

Beans are very sensitive to both cold and wet and it is useless to plant them before the ground has become dry and warm. The largest returns will result from planting in drills from two to three feet apart. Cover the seeds one and one-half to two inches deep and thin the young plants three to six inches apart in the row. If planted in hills, make the hills about two feet apart each way. For succes作 sion, plant at intervals of one to two weeks till midsummer. The plants up to the time blossoming should have frequent shallow cultivation, but any mutilation of the roots by cultivation after the plants always be very shallow and it is useless to expect a crop from a field so poorly prepared as to need deep stirring after planting.

We give careful attention to selecting and improving the different varieties and keeping them pure and we invite the most critical comparison of our stocks with those of any other grower.

The varieties of garden beans we offer havebeen separated for convenience into five groups: Wax Podded Dwarf or Bush sorts, Green Podded Dwarf or Bush sorts, Dwarf Limas, Pole or Running sorts and Pole Limas. Nearly all of these sorts, except the Limas, are suitable when young for use as snaps, which in some localities are called "snapshorts." Thelow growing sorts are called Bunch beans in some sections. In northern latitudes the term "butter-beans" is often applied to low growing wax podded sorts. In the west, however, by "butter-beans" is usually meant limas.

Write for special prices on larger qualities.

\section{GREEN-PODDED DWARF BEANS}

REFUGEE, OR THOUSAND-TO-ONE-Very tender and productive best variety for pickling. Pkt., 10c; 1b. 30c; 10 lbs., \$2.50.

EARLIEST RED VALENTINE-One of the earliest and most prolific round green podded Beans. It will remain in a perfect condition for nearly two weeks after picking. Pkt., 10c; 1b., 35c; 10 lbs. \$2.50.

BURPEE'S STRINGLESS GREEN-POD - The earliest and most hardy, absolutely stringless. The pods are a rich green, very round

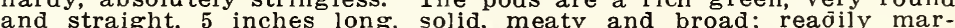
and straight, 5 inches long, solid, meat
keted. Pkt., 10c; lb., 35c; 10 lbs., $\$ 2.50$.

ENGLISH OR BROAD WINDSOR-The celebrated Broad Bean of England, growing on a strong stalk about 2 feet high. Beans eaten shelled. Pkt., 10c; lb., 30c; 10 lbs., \$2.50.

LONG YELLOW SHX WEEKS-An early standard variety, mucr prized for its productiveness and excellent quality: the pods are often 8 inches long, tender and brittle; vines vigorous and branchoften 8 inches long, tender and brittle
ing. Pkt., 10c; lb., 30c; 10 lbs., \$2.50

ROUND YELLOW SIX WEEKS-While this does not differ greatly from the Early Yellow Six Weeks in the appearance of the plants, the pods are shorter, much thicker fleshier and mature earlier; the plants are usually shorter and more compact. The pods are about plants are usually shorter and more compact. The pods are about able for early snaps for the home garden and market. Seed medium sized, round, light yellow with darker marking about eye. Pkt., 10c; lb., 30e; 10 ibs., \$2.50.

\section{WAX OR YELLOW-PODDED DWARF BEANS}

DAVIS WHITE WAX-Of compact, upright growth, producing a large yield of handsome, long pods of a clear waxy white color, and when of suitable size to use for snaps, quite stringless. The dry Beans are clear white, and are unsurpassed for baking. Pkt., 10c; Beans are clear white,
lb., 30c; 10 lbs., \$2.50.

IMPROVED PROLIFIC BLACK WAX-In every respect first-class; pods nearly round, of a heautiful bright yellow color, hanging in clusters well up from the ground; very early and continues long in bearing which, with its immense productiveness and handsome appearance makes it everywhere popular. Pkt., 10c; lb., 30c; 10 1bs., peara.

IMPROVED GOLDEN WAX-The standard flat, wax-podded variety. The plants are of vigorous, bushy growth, not susceptible to rust, moderately early and very profific. The pods are exceedingly handsome, large, uniformly broad, thick and almost all solid flesh, of good quality, tender and brittle, without string or coarse fibre at all stages until maturity. While the color is a rich golden yellow. Pkt., 10c; lb., 30c; 10 lbs., \$2.50.

VENTURA WONDER WAX-This bean is of California origin, and a very valuable addition to the wax varieties. It is a stocky variety of bush, bearing large numbers of long flat, yellow podded beans, containing white seed, that have a fine flavor Either used as a snapped bean or dried for winter use. We recommend this bean lbs., \$3.00.

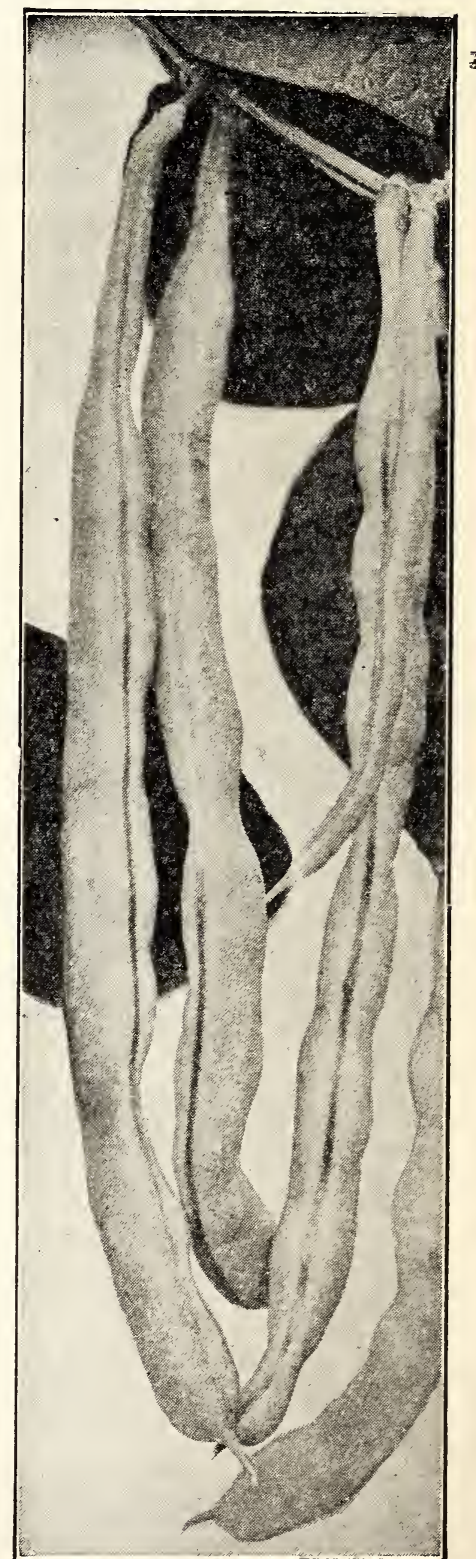

Long Yellow Six Week 


\section{BEANS--Pole or Running}

These beans require a pole or trellis to climb on, if planted in the garden, although when raised as seed crop in the open field they need no support whatever. Pole beans are usually very prolific, and bear longer pods and a great many more of them than the bush varieties. For home garden use set the poles well in, first scrape the soil away to a depth of two inches and irrigate well. Then plant 5 to 9 beans in each hill, covering to a depth of one inch. Save only the best three or four plants. Pole beans will continue bearing long after the earlier bush varieties have ceased. Hills should be three to four leet apart each way.

\section{Green-Podded Pole Beans}

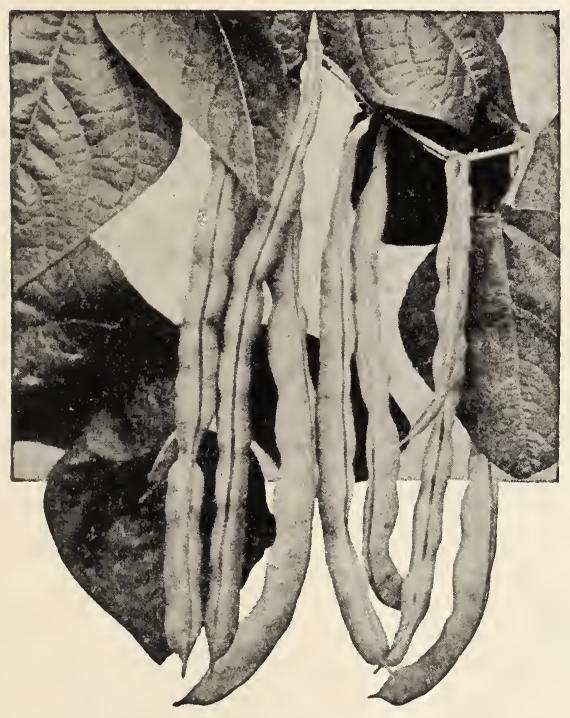

Kentucky Wonder

\section{KENTUCKY W O N DER OR OLD} HOMSTEAD-Vine vigorous, very productive, bearing its pods in clusters; pods green, very long, often reaching nine or ten inches, nearly round and very crisp. Ten days earlier than any other greenpodded pole bean. Good market sort. Pkt., 10c; lb., 30c; 10 lbs., \$2.50.

YARD LONG-A great curiosity, and of excellent quality. Pods usually 18 to 24 inches, but frequently 30 inches and sometimes 36 inches in length. An excellent table vegetable, being tender and of a rich asparagus flavor. Plant this fine bean for home use and exhibition purposes. The dry beans are kidney-shaped, of dark brown color. The vines keep on bearing for a long time. Pkt., 10e; oz., 40e; lb., \$4.00.
TALL HORTICULTURAI OR SPECKLED CRAN BERRY - This old standard shell bean produces compact plants with large leaves and is very productive. The young green pods are tender and of good flavor, slightly curved, and attain at maturity a length of 5 inches, being colored greenish yellow, speckled with carmine. This variety is used very largely for shelled beans for soup and baking purposes, but is also very popular as a gaking purposes, but is also very popular as a green-podded snap bean, as the pods are
stringless. Pkt., 10e; lb., 30e; 10 lbs., \$2.50.

SCARIET RUNNEIR-An old favorite, used both as string and shelled beans It is an excellent snap variety producing an abundance of large green pods. In addition to its culinary value, Scarlet Runner is useful for ornamental purposes. The strong, rapid growing vines bear brilliant scarlet flowers from early summer until late fall, and may be used to good advantage for training over porches and trellises. Pkt., 10e; lb., 35e; 10 lbs., $\$ 3.00$.

\section{WHITE KENTUCKY WONDER}

A very popular and satisfactory type of the Kentucky Wonthe Fientuck il was introduced a fe w years ago and since then it has been growing in popularity by leaps and bounds until now it is a most desired variety.

Improved W hit Kentucky W o n d e Bean is a pole Bean is a pole bean of a tenderness that places it in the iront rank of the bean family: Its productiveness is so exceptional that any one planting a bean garden should not be without it, and as for the market gardener. it will be impossible for him to find a bean that will yield greater returns per acre. It is earlier by two weeks than the other types of Kenother types of Kentheky Wonders and the Market Gardener, $w$ h o is w id the big returns are made by harvesting a heavy crop early.

Its $t$ e $n$ de $r$ e s $s$, crispness and color make it very desirable. The pods av able. The pods av erage from eight to ten inches in length and are of a deep g r e e $\mathrm{n}$ shade. The seeds when dry are of a snowy whiteness. Prices: 10e per nkt.; 1/2 lb., 20e; 1 lb.

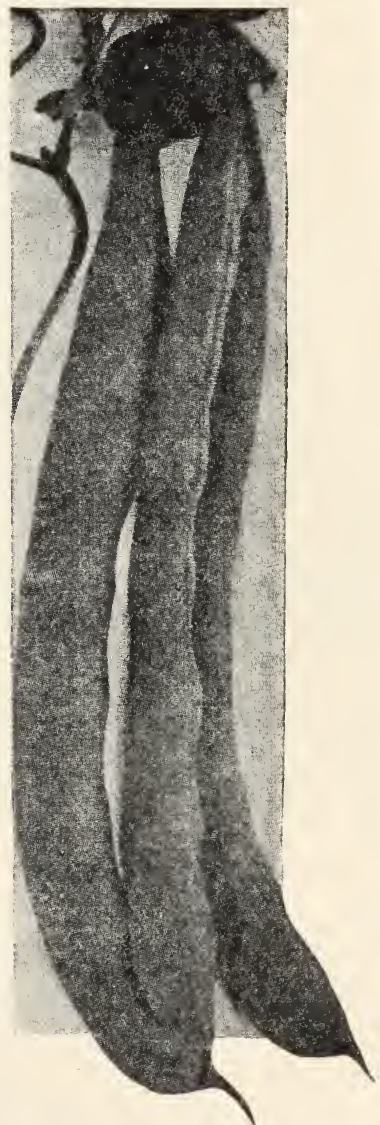
35e; 10 lbs. $\$ 3.00$.

IKENTUCKY WONDER IVAX-Equal in quality to Old Homestead, but the pods are broad and a golden waxy color that makes them very attractive. This variety is likewise an abundant yielder and we consider it the best of the yellow-podded pole beans. Pkt., 10e; lb., 35e; 10 lbs., \$3.00. 


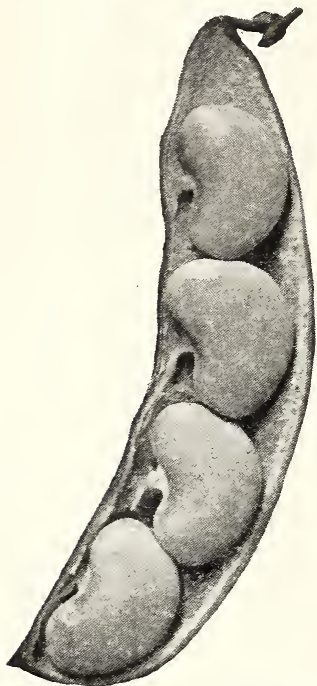

\section{LIMA BEANS}

FORDHOOK BUSH LIMA-This variety is decidedly our preference among the bush lima beans It is nearly as early as any. The pods are about four inches long, of medium size, well filled, the beans very thick, tender and of fine quality. The plants are very robust, never coming into contact with the ground. It yields continuously all summer, in this respect superior to any other sort. Pkt., 10e; 1/2 lb., 20c; 1b., 35c; 10 lbs., \$3.00.

KING OF THE GARDEN LIMA-POLE-Th is is the largest of the limas and is one of the best for the main crop. It is a very strong grower and very large podded, the pods being very uniform. Thebeans are medium to large, flat, greenish-white in color. It is a heavy yielder and a variety that climbs and produces until the end of the season. Pkt., 10c; 35e; 10 lbs., \$3.00.

BURPEE'S IMPROVED BUSH LIMA-A true bush form of the Large White Lima Bean Fairly early pods of good size and well filled. Strong plants with thick stems, furnishing a good support. The quality is excellent and also the yield. Pkt., 10c; 1b., 35c., 10 lbs. \$3.00.

HENDERSON'S BUSH LIMA-This is a small white Lima Bean which grows in bush form and produces a large crop. The plants are very hardy, make rapid growth and are not so apt to throw runners as some of the other varieties of Bush Limt. It begins to set pods at an early season. Most exquisite table quality. Pkt., 10c; lb., 30c; 10 lbs., \$2.50.

\section{Knox's Improved Cabbage}

No special care or soil is required to grow cabbage as it will grow in any soil with proper cultivation, but good seed is extremely important with this crop. Like cauliflower and lettuce it is not a good summer crop as it will not head up in extremely hot weather. For fall and winter crop sow the seed in May and June, for spring and early summer sow in September and October. Transplant when the plants are about six weeks old 18 inches apart in rows 30 inches apart. To keep heads from splitting when ripe loosen the plants a little at the roots.

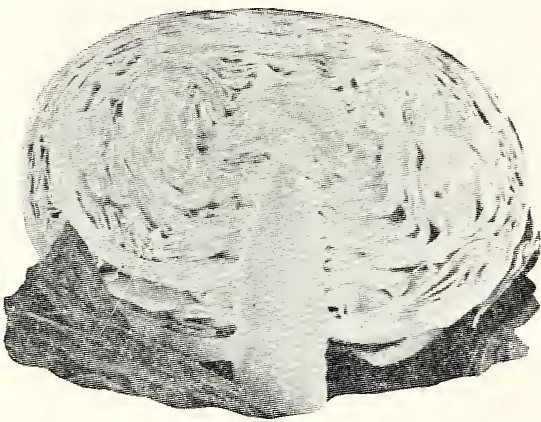

DANISH BALLHEAD-For late crop is a tallstemmed, spherical, hard-heading variety it cannot be excelled. Pkt., 10c; oz., 35c; 1/4 lb., \$1.00; 1b., $\$ 3.00$.

SAVOY GREEN GLOBE-The favorite for market SAVOY GREEN GLOBE-The favorite for market gardeners. Leaves are wrinkled and dark green. lent in quality and sure header. Pkt., 10c; oz., 35e 1/4 1b., \$1.00; 1b., \$3.00.

PREMIUM LATE FLAT DUTCH-As a variety for winter market it has no superior. Heads are for winter mark on large, bluish-green, round, solid, broad and flat on top: they open white and crisp, are tender and well flavored. It is a fall and winter variety, and one of the best

EARLY JERSEY WAKEFIELD-Deservedly one of the most popular early varieties. Small heads of are very solid, Our stock is of the best and runs true and
form. Pkt., 10e; oz., 30c; 1/4 1b., 80c; 1b., \$2.75.

MAVMOTH ROCK RED-The largest and surest heading of the red cabbages. Medium length stem: head medium large, round, solid, and of a handsome dark red color that is carried into the heart. Pkt., 10c; oz., 30c; 1/4 lb., 80c; lb., \$2.75.

COPENHAGEN MARKET - The earliest large round or flat-head sort. The ripening is early and uniform, maturing at one time and almost with uniform, maturing at one tersey Early Jersey arkeraging season, the heads are remarkably large, averaging ten pounds in weight. It has few outer leaves, which permit close planting, and it grows close $1 / 4$ 1b., \$1.00; 1b., \$3.00.
EARLY WINNIGSTADT-Sure to head, regular conical shape, very hard and hardy, a good keeper winter and summer, one of the best for general use. Best imported seed only. Pkt., 10c; oz., 30c; $1 / 4$ 1b., 80c; 1b., \$2.75.

EARLY FLAT DUTCH-The seed we have of this variety is very select. Practically all of the truck gardeners use this strain, as every plant will form a large even size solid head and matures early and evenly. The seed we offer of this variety is grown for us and is acclimated. Seed that is not acclimated us and is acclimated. Seed that is not going to plant cabbage and you are not positive going to plant cabbage and you are not positive take by planting our Early Flat Dutch. Pkt., 10c; oz., 30c; 1/4 lb., 80e; 1b., \$2.75.

EARLY YORK-This well known cabbage deserves rightfully the attention of every vegetablegardener. It is always of good size. forming round, pointed heads with few loose outer leaves; but those covering the head are thick and stout, giving good protection to the tender inner leaves. For this reason, the cabbage is admirably adapted for wintering, and very early setting. Pkt., 10c: oz., 30c; 1/4 1b., 80c; lb., \$2.75.

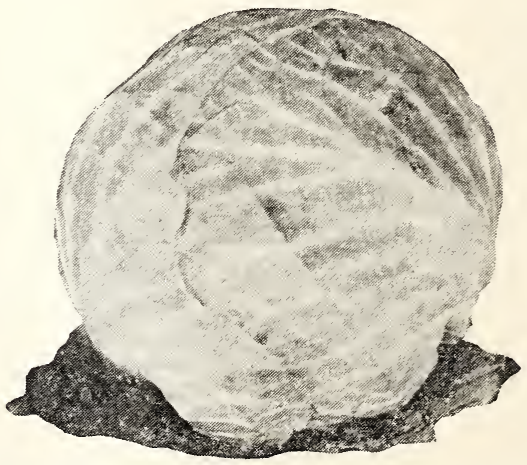

WONG BOK-This is the original Chinese-grown strain. producing a heavier and more solid head than the Pe-Tsai variety. Has a deliciously mild cabbage flavor, and the pale green, closely wrapped leaves blanch to almost pure white. Our select strain produces heads of remarkably solidity. Sow about August 1, and cultivate like lettuce or late about August 1, and cultivate like lettuce or late cabbage. In setting the plants out, push down about $11 / 2$ inches in the ground and set 1
apart in the row. Pkt., 10c; oz., 45c; lb., \$4.50. 


\section{Knox's Superior Beets}

Beets may be planted almost all the year round where the temperature does not linger below 25 degrees. Sow the seed one inch deep in well prepared, moist soil in rows eight or ten inches apart, or on ridges same as lettuce. Drill eight pounds of seed per acre. Thin out to one plant every three inches and transplant the discarded plants in any convenient spot about the garden. The Egyptian is a small, dark red, 1'lat, smooth variety. It is sweetest and best for the table. Irrigate about every two weeks, unless the nature of the soil is such that more frequent irrigation is found to be necessary. Mulch the soil after each irrigation. Beets are ready for use in ten weeks and continue in prime condition for another ten weeks. Two ounces of seed for 100 feet of row.

CROSBY'S EGYPTIAN-This variety is extremely early and is a good one to use for forcing, having a small top of green leaves tinged with brown. The thick, roundish, smooth root has a distinct vermillion colored flesh zoned with lighter shade. Pkt., 10e; oz., 15e; 1/4 lb., 30e; Ib. 75e; 5 Ibs., \$3.25.

DETROI' DARIK RED-This variety is of exceptional fine quality and attractiveness. The root is almost globe-shaped. tapering slightly and smooth. The flesh is a deep vermillionred, crisp, and sweet. Leaves are green with dark red veins and stems. Pkt., 10e; oz., 15e; 1/4 Ib., 30e; Ib., 75e; 5 Ibs., \$3.25.

ECLIPSE-This variety is extremely early. of small size, but grows very rapidly. Its very fine quality round shape. smoothness, and deep red color make it a favorite. It has a scant top, with brown-red foliage. Pkt., 10c; oz., 15e; $1 / 41$ lb. 30e; Ib., 75e; 5 lbs., \$3.25.

EARLY BLOOD TURNIP-This is our choice for the early sort and is best for forcing. The root is decidedly flattened turnip-shaped, and the flesh is very dark bloodred. The top is small with brown-red leaves mixed wit: green. For rapid maturing of roots. this variety is unsur passed. Pkt., 10e; oz., 15e; 1/4 lb., 30e; lb., 75e; 5 lbs., \$3.25.

LONG SMOOTH BLOOD-(Out of ground). This is the best of all long late varieties, producing a root from 12 to 14 inches long, growing one-third out of the ground. The flesh is deep red, and the leaves are green, veined with red. This

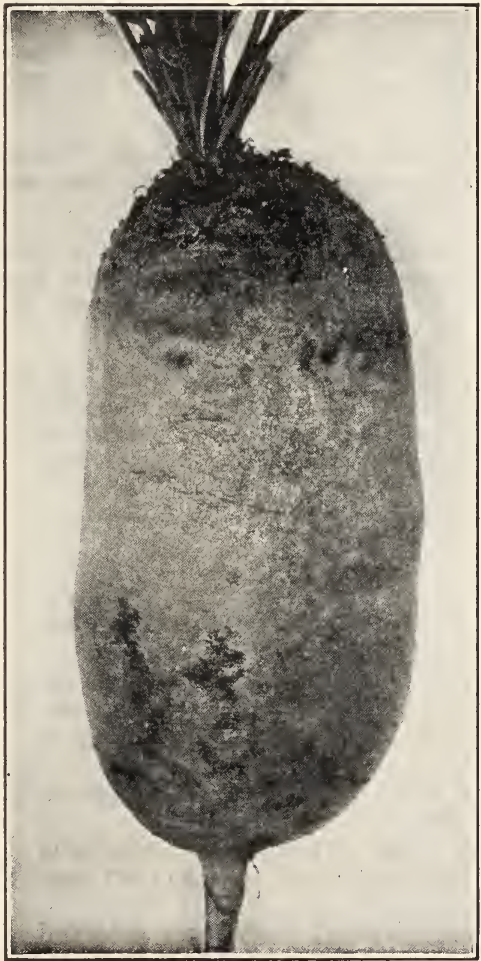

Golden Tankard

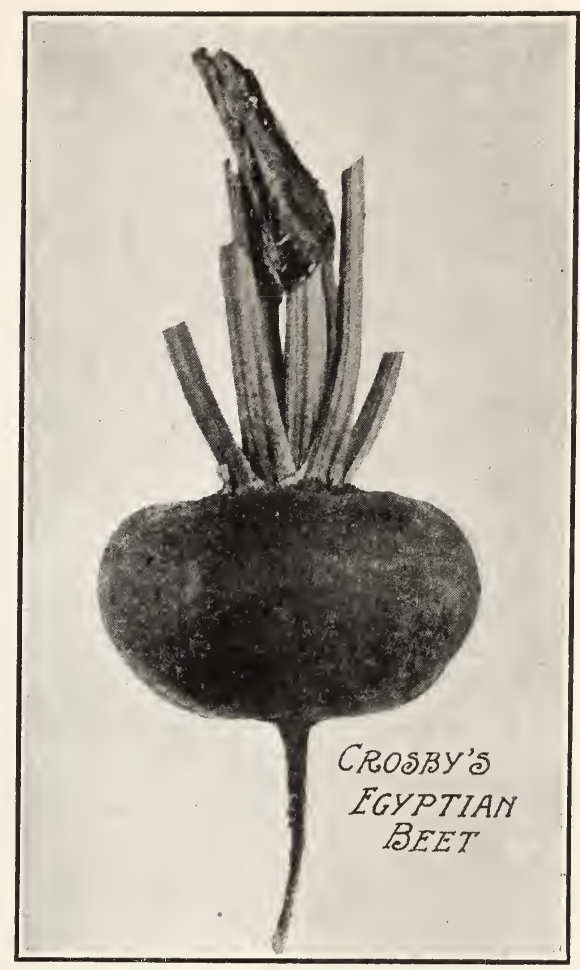

beet keeps well through the winter. Pkt.. 10e: oz.. 15e; 1/4 lb., 35e; lb. $\$ 1.00 ;$ 5 lbs., \$3.50.

\section{MANGEL- WURZELS}

LONG RED-Our stock of this variety has been grown in $\mathrm{Hol}$ land and is the result of continued careful selection. It is the heaviest-yielding Mangel there is, producing under proper conditions from 40 to 80 tons per acre, many specimen roots weighing from 40 to 50 nounds, and being of fine texture and good quality. Pkt., 10e; Ib., 50e; 10 lbs., \$4.50.

GIANT HALF-SUGAI-A splendid Beet for stock-feeding purposes, as it is more nutritious than the ordinary Mangel-Wurzel, containing 25 per cent of sugar. Grows half out of the ground and is an enormous yielder. The outer skin is white, with a slight pink tint at the top; flesh clear white. Pkt., 10c; 1b., 50c; 10 lbs., \$4.50.

\section{GOLDEN TANKARD STOCK BEET}

SELECTED GOLDEN TANKARD-Most nutritious variety in cultivation; roots large, ovoid, but filled out at top and bottom, terminating with a small tap-root; flesh deep golden yellow, solid, crisp, sweet and rich: excels all others in milk-producing qualities and very productive. It has no superior as a keeper. Pkt., 10e; Ib., 50e; 10 Ibs., \$4.50.

\section{SUGAR BEETS}

FRENCH WHITE SUGAR-The sort most generally grown, as it combines, with heavy yield, a good percentage of sugar. It has produced 30 tons of Beets to the acre, and contains from 10 to 13 per cent of sugar. The largest yields known have heen obtained from this variety. Pkt., 10e; lb., 75e; 10 lbs., \$6.50. 


\section{Knox's Carrots}

This delicious and nutritious vegetable is not appreciated as it should be. Properly cooked, it is a great delicacy. Its feeding qualities for stock are excellent. A sandy soil is best, but any good rich soil will produce good crops. Sow in early spring in rows fifteen to eighteen inches apart and thin to three to four inches according to size and variety. Cover the seed only half an inch and give careful cultivation throughout the season. They may be eaten either when a half inch or so in diameter.

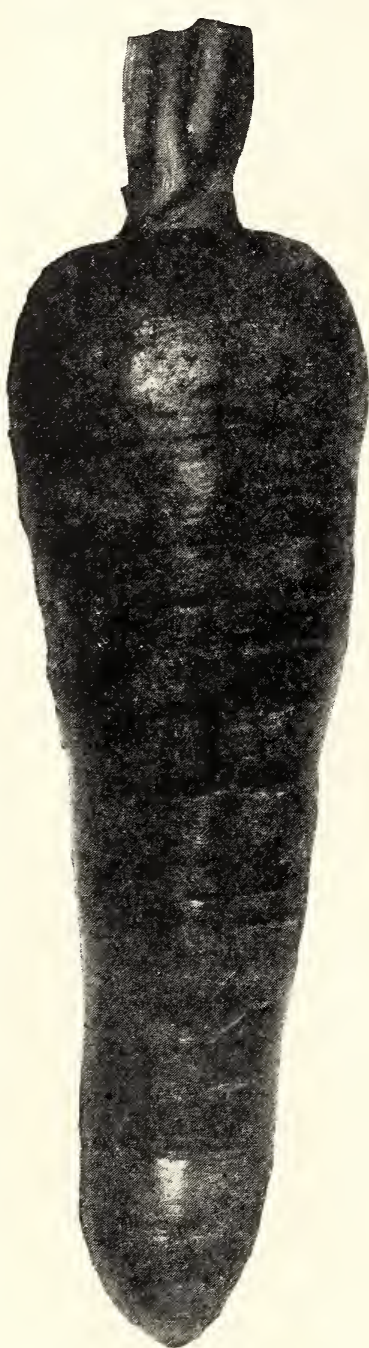

Danvers Half Long
DANVERS HALF LONG-Without question one of the finest carrots, rich orangu color, smooth stump rooted, flesh of fine texture smooth, stump rooted, flesh of fine textur and with little core, more extensively planted than any other by market gardeners, and also one of the best sorts for the home garden. Pkt., 10c; oz., 15e; $1 / 4$ 1b., 25e; 1b., 75e.

LO NG O R A N G E I MPROVED - The standard late variety, ve $\mathrm{r} y$ productive and of good quality. Roots poin ted a nd pointen 12 inches lo $\mathrm{ng}$, fairly smooth and of a deep orange color. Often us ed for stock feeding. Pkt. $1 / 4$ 1b., 25e; Ib., 75e.

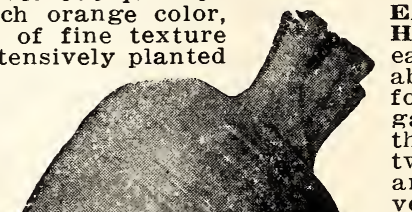

RLY SCARLET HORN - A small early variety suitable either for forcing or early garden use. Roots three inches by two, attractive or ange color and very fine quality. pkt 1/4 Ib., 25e; 1b. 75e

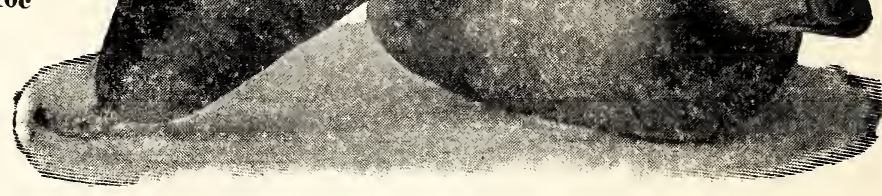

CHANTENAY - A medium early productive variety of very fine quality. Root five inches long, two and one-half inches in diameter, deep orange, fine grained, flavor excellent. One could hardly say too much in praise of this very popular variety. Pkt., 10e; oz., 15e; 1/4 1b., 25e; 1b., $75 c$.

LARGE WHITE BELGIAN-For Stock. Root pure white, green above ground. It will grow to a very large size, and is easily gathered. Flesh rather coarse. Is raised extensively for stock. Pkt., 10c; 1/4 1b. 20e; Ib., 70e.

EARLIEST FRENCH FOIRCING-Used extensively for forcing. Small, globe--shaped root of orange-red color; excellent quality. Pkt., 10c; oz., 15e; $1 / 4$ Ib., 25e; Ib., 75c.

OXHART or GEURANDE-Roots are very thick, five inches long and nearly as broad, and very blunt at the lower end. It grows rapidly and the roots often weigh a pound or over. Excellent quality. Pkt., 10c; oz., 15e; 1/4 1b., 25e; 1b., 75e.

ST. VALERY-This kind can be considered as a link between garden and field carrots. It grows a large, long, red root, which is remarkably tender, crisp and well flavored, and placing it on the list of field-carrots is due to the big returns it gives. Pkt., 10c; oz., 15e; 1/4 1b., 20e; 1b. 70c.

\section{CARROTS A MAIN GROP}

In the last few years carrots have become one of the main crops of the vegetable grower and shipper. Besides the local home market there has been developed a large market in the east for winter shipping.

During the winter in the east many of the vegetables offered on the market are from storage. You can readilly see what a demand for fresh vegetables there is at this time. Carrots can be bunched and packed in crates or the tops cut off and sacked. Bunching is the best however as they are much more attractive.

Chantenay, Half Long, Long Orange, and St. Valery are the best varieties for this market. A yield of 500 sacks or 800 crates is not uncommon for this variety of carrots.

For eastern shipment the seed should be sown in September. The growers of asparagus are using carrots to fill the first cars of asparagus until the asparagus cut reaches enough volumne to load straight cars.

Those interested in planting acreages of carrots for the trade should plant our selected strains. See us for prices in quantity. 


\section{Knox's Celeriac and Celery}

Celery seed should be sown indoors from February 20 th to April 20th, or outdoors in April. Cover lightly, keep the beds moist, almost to wetness, and the temperature should not exceed sixty degrees. Outdoors it is sometimes necessary to furnish partial shade with lattice work that admits about half the sunliors sunight. Keep the small plants are of the roots. The soil must be rich and moist or else water should be available for irrigation. Transplant the last of June or first of July, although it is sometimes possible to mature a crop set out as late as the middle of August. In setting dig trenches 5 inches deep, 2 feet apart. Plant 1 foot apart along both sides of trench. Water often and keep the weeds down by cultivation and hoeing. Blanching is done by heaping up the soil or with two wide boards placed on each side of the rows and held in place by stakes or wire hoops at the top. The latter method is necessary when blanching in hot weather for the early market. Be careful not to disturb the plants while wet, as this increases the tendency to rust.

\section{CELERIAC}

Sow the seed same as celery. Transplant into rows two feet apart and thin to nine inches in the row. Cultivate thoroughly. It is not necessary to earlh up.

LARGE SMOOTH . PRAGUEThis is the most popular variety with American growers. Roots nearly globular, comparatively smooth with few roots at the bottom, flavor excellent. This variety excels all others in appearance, size and quality. Pkt. 10e; oz., 30e; $1 / 4$ lb., 90e; lb.. \$4.00.

NON PLUS ULTRA-A large rooted variety, combining tenderriess with size. The flesh is clear and White. Pkt $10 e ; 0 \%, 30 e^{1 / 4}$ lb., 90e; lb., \$3.00.

\section{CELERY}

\section{GOLDEN PLU.ME} OR WONDERFUL

A variety of quite recent origin as an early celery whether for shipping or for home market has become quickly popular, and in some sections is preferred to the Golden Self-Blanching, as it is a week or ten days earlier. It is cor is yellow pearly white color a beautiful pearly white color and the indifinest flavor, brittle and without any stringiness. In growth the plant is stout and stocky. It is more resistant to disease than the other self-blanching types. This is the variety which is making Oregon famous for superfine celery. Pkt., 10c; oz., \$1.00; 1/4 lb., \$2.50; lb., \$10.00.

GIANT - PASCAL - Vigorous compact, productive variety; one of the best sorts for fall and winter use. Leaves upright, short, dark green. Stalks short, broad, very thick, crisp and tender, blanching readily to a yellowish white color; a very good keeper. Pkt., 10e; oz.. 40e; $1 / 4$ lb. \$1.35; ib., \$4.00.

WHITE PLUME PEREECTED - An early distinct variety, with a silver-white color in its inner leaves, stalks and heart. Crisp and of excellent quality. It requires little to blanch it, making a t $\mathrm{r}$ a ctive white stalks and leaves. Pkt. 10c,; oz., 30c; 1/4 lb.,

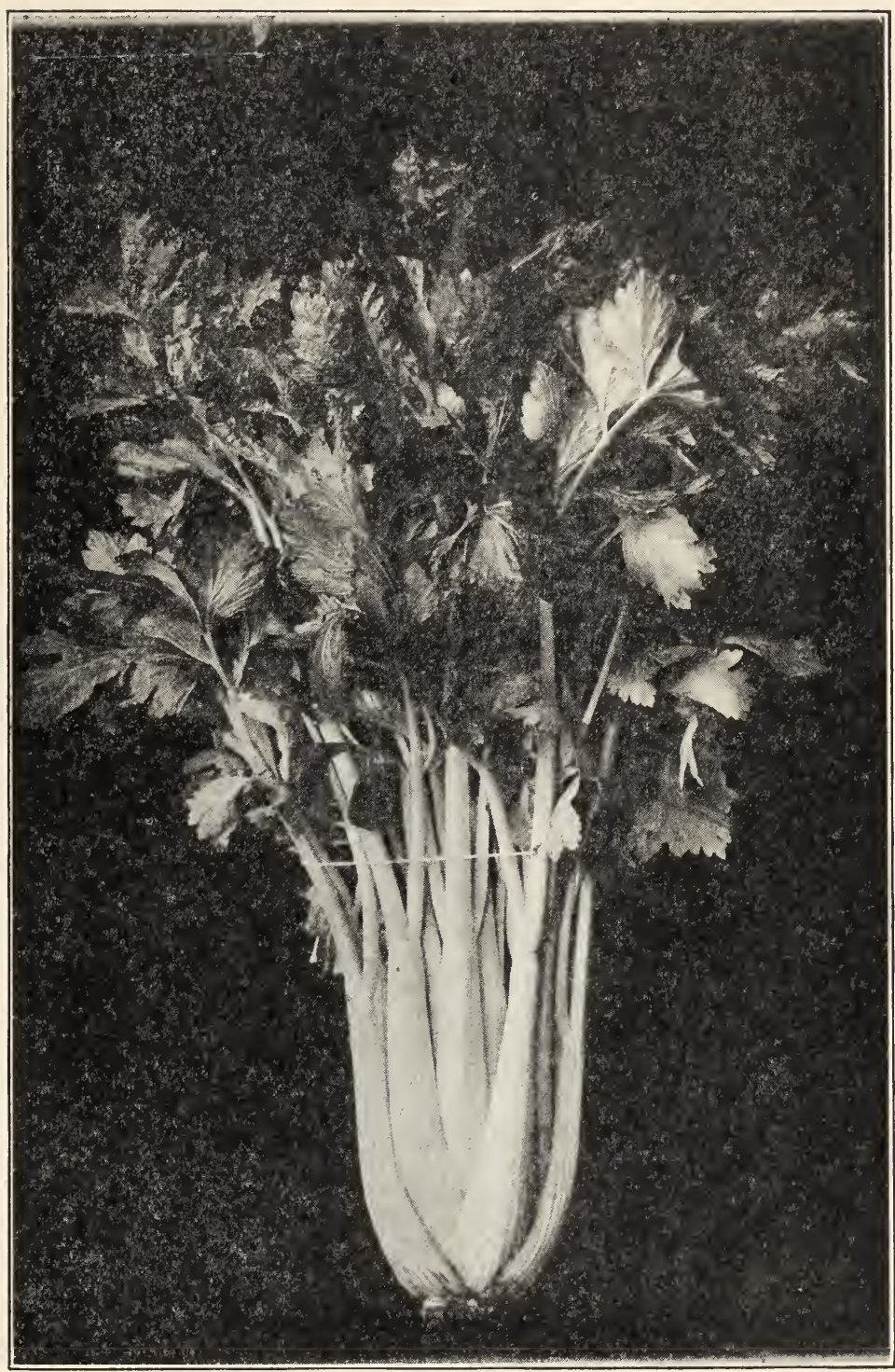
$\$ 1.00 ;$ ib., \$3.00.

GOLDEN SELF-BLANCHING, OLD TYPE-OU stock of this famous variety, now considered a standard celery for early use, is unsurpassed. The plants produced by our seed are compact and stocky, with yellowish green foliage turning to golden yellow, with a slight earthing up. Stalks are very thick, broad, solid and crisp, of the finest nutty flavor and natural ivory-white color This is a big hearted strain with no hollow stalks,
extremely even and free from green top. Pkt., 10; $1 / 2$ oz., 60e; oz., \$1.00; 1/4 lb., \$2.50; lb., \$10.00.

GOLDEN SELF-BLANCHING-Tall or New Type - Similar to the short golden self-blanching but much taller. A wonderful home market variety, but not desirable for shipping. Pkt., 10e; oz., \$1.00; $1 / 4$ lb., \$2.50; 1 b., \$10.00. 


\section{Knox's Famous Cauliflower}

Cauliflower is grown the same as cabbage, but requires more fertile soil, and like cabbage and lettuce is not a good summer crop. There are two good seasons for sowing cauliflower seed; for fall and winter sow the seed in June and July, for spring sow in September and October. Transplant the plants when they are about six weeks old, and always keep them in a thriving condition. If large or old plants are used and if they are not kept growing constantly, some will head prematurely and others will go to seed.

DRY WEATHER Or DANISH GIANTThis variety is of vigorous and dwarf growth, and produces stone-hard and snow-white heads, unsurpassed in quality. The foliage is very heavy, fully protecting the heads, which are less liable to blight in hot weather than those of the earlier sorts. As indicated by the name, for dry, hot climates it is to be preferred to all other sorts, being a sure header there when other sorts fail. If thoroughly cultivated and well enriched, est yield. Pkt., 25e; oz., \$1.75.

VEI'TCH'S AUTUMN GIANT-Plants are large and late with dark green leaves and heavy mid-ribs. The heads are large and solid, though rough-protects well in the winter, but if headed too early may have to be tied. Can be seeded May to July and will head from November to January. Pkt $\$ 1.75 ; 1 / 4$ lb., \$5.00.

EARLY SNOWBALL-This variety has attained a degree of excellence that has made it a highly prized strain the world over, proving beyond peradventure that real good pedigreed cauliflower seed is the paramount essential that makes the resultant crop profitable. An extra early variety. Uniform heads of quite large size, handsome form and exquisite quality which are good sellers in any market. Pkt., 25e; oz., \$1.75.

EARLY PERFECTION CAULIFLOWER -Is a very early variety of the Dwarf Erfurt type. It is not quite as early as the Snowball. The leaves are exceptionally long, stand straight up, making the inner leaves curl over and protect the head. It is perfectly true to type and its contemporarity in maturing makes it possible to clear off the ground at one cutting. Pkt., 25e oz., \$1.75.

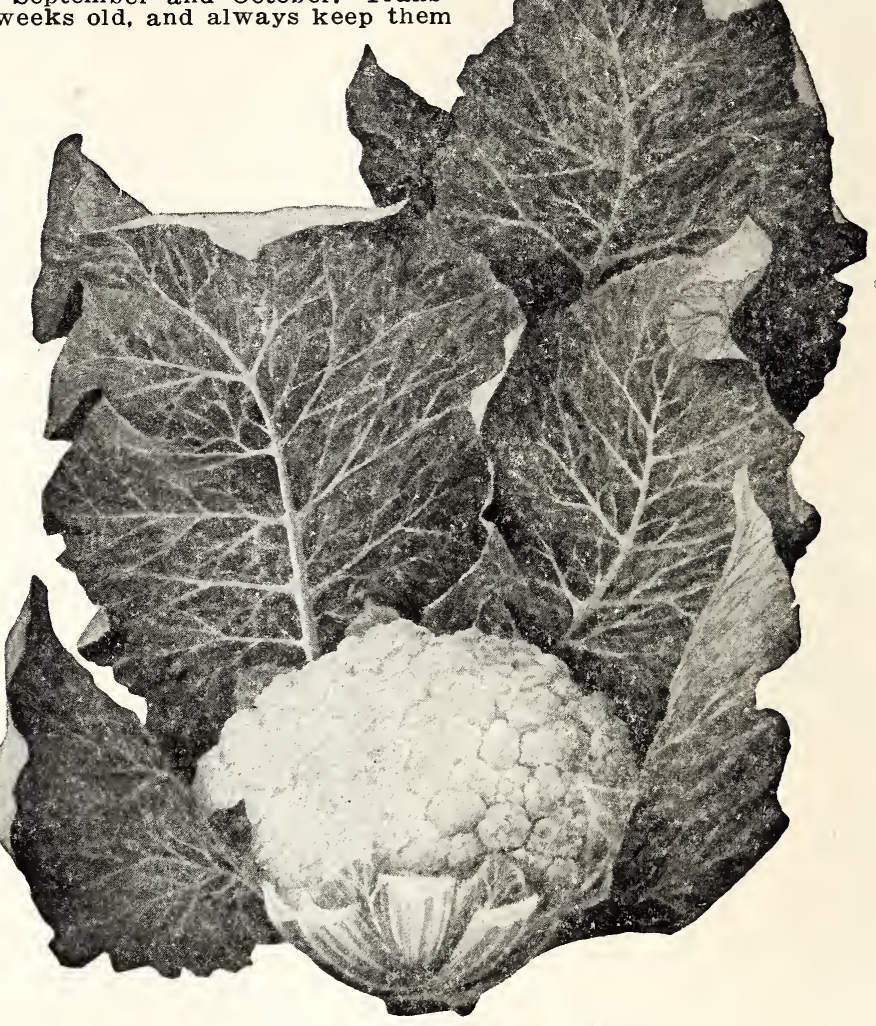

Dry Weather or Danish Giant

SWISS CHARD

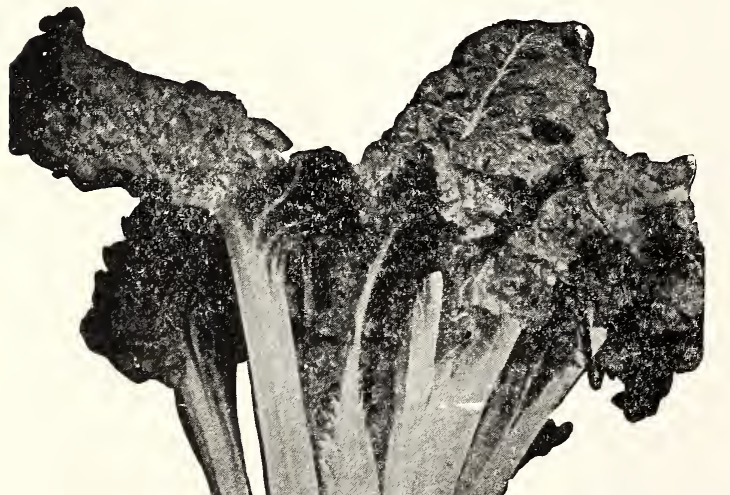

Swiss chard is one of the easiest vegetables to grow. Planted in the spring time it will grow ne whole year before running to seed and produce an abundance of green leaves the whole year. The broad, white stalks can be cooked like asparagus and the green leaves used the same as spinach. In picking always pick the largest outside leaves and the plant will continue to produce leaves from the center. It is also one of the best greens to plant for poultry as it will produce more greens with less care and through a longer season than anything else.

WHITE-Grown for the leaves only, and cooked like spinach. The midrib is prepared like asparagus. It is hardy and productive, with broad green leaves and large white midribs or chards of excellent quality; sown at different seasons of the year, giving successive greens. Pkt., 10e; oz., 15e; 1/4 lb., 30e; 1b., 75e.

LUCULLUS-A peculiarly delicious variety having green leaves which are remarkably crimpled and curled, like savoy-leaved cabbage. The chards are white and broad but not so broad as the common variety, although equally fine in flavor. Pkt., 10e; oz., 15c; 1/4 1b., 30e; lb., 75e.

\section{CHICORY}

LARGE ROO'TED-The roots are cut in thick slices, then roasted and used as a substitute for coffee. In spring the leaves make a nice salad. Reaches maturity in 65-75 days. Pkt., 10e; oz., 25e; $1 / 4$ 1b., 80e; 1b., \$2.50.

WITLOOF CHICORY - This is known also as French Endive and is esteemed as the finest of all green salads. Spring-sown seed produce by fall large parsnip-like roots,. One packet will sow about 25 feet of row, producing about 100 roots. One ounce is enough for 100 feet of row.

seed-of true Witloff. 10c per pkt.; $25 \mathrm{c}$ per oz., $1 / 4 \mathrm{lb}$, $80 \mathrm{c}$ 1b., \$2.50. 


\section{Knox's Sweet Corn}

One of the garden's sweetest vegetables. Plant from February 15 th to August 1 st, in rows 3 feet apart, drop 6 or 7 kernels in hills every 18 inches in the row and thin out to two of the healthiest plants in each hill when about 5 inches high. Break off all side shoots except the two top ones as they will produce the largest and best ears. Corn is at its very best when picked and eaten within an hour. but it is extremely important that it be picked just at the right time especially when not too old. Frequent plantings of several varieties in sucession will keep a good supply available all summer.

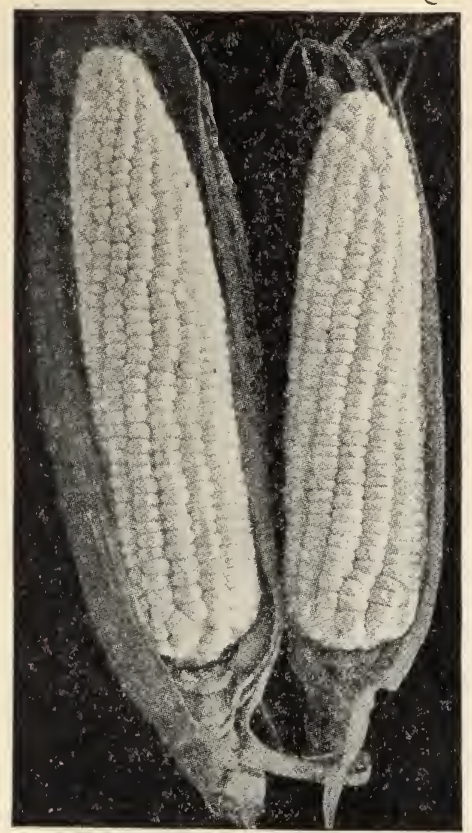

Stowell's Evergreen

MARKET GARDENER'S SWEET CORN-Our market gardeners sweet corn is far superior to any other variety we know of. It is very early and bears two large size ears to each stalk. We do not hesitate to recommend this variety and if you do not know what variety of corn to plant, try our Market Gardeners. Pkt., 10e; lb., 30c: 10 lbs., \$2.50.

GOLDEN BANTAM-There is something about yellow sweet corn on the ear for table use that appeals to old and young alike. To those who prefer a yellow variety we especially recommend Golden Bantam. Its flavor is extremely sweet and delicious, its kernels tender and juicy. Its hardiness permits planting earlier and in colder and damper soil than other varieties. Plant it at regular intervals to obtain a continuous supply during the season. In our latitude it can be planted as late as the middle of July. The stalks grow from 4 to 5 feet in height and generally produce two ears, which are 5 to 7 inches long and of a bright golden yellow color when ready for the table. It is one of the sweetest, most delicious and toothsome of the sweet corns. Matures in about 70 days. Pkt., 10e; lb., 30c; 10 lbs., \$2.50.

EARLY MAMMOTH or ALAMEDA-A vigorous, large, early variety grown extensively in Alameda County for the San Francisco market. Pkt., 10e; lb., 30c; 10 lbs., \$2.50.

EARLY MINNESOTA-Very early; ears of fair size and uniform; plant rather dwarf; one of the best. Pkt., 10c; 1b., 30c; 10 lbs., \$2.50. STOWELL'S EVERGREEN - Now recognized everywhere as a standard variety, both for home use and market, and is the general lavorite. The ears are of large size, grains deep, exceptionally tenother. Pkt., 10c; lb., 30e; 10 lbs., \$2.50.

COUNTRY GENTLEMAN-One of the finest of all corns for the private table. Ears 8 to 9 inches long, cob small and irregularly crowded from end to end with pearly white kernels of great depth; quality surpassingly sweet and tender. Pkt., 10e; 1b., 30c; 10 lbs., \$2.50. EXTRA-EARLY CORY-Of great value for its extreme earliness;
is 10 days earlier than any other sort; ears of good size and firstrate quality. Pkt., 10c; lb., 30c; 10 lbs., \$2.50.

Ask for prices on larger quantities.

EARLY ADAMS-An extra early variety of the semi-sweet type. Does very well in the interior valleys of California, as it is not bothered much by bugs. Pkt., 10e; lb., 30e; 10 lbs., \$2.50.

EARLY EVERGREEN-This corn is positively one of the earliest of the very large eared sweet corns. Ears measure 10 to 12 in. It matures in sweet, very lut vor vasweet, very luscious, tender and palatable. No matter what other varieties you

OREGON EVERGREEN-The husk is very thick and folds so tightly ver the grains that the worm does very little damage, compared with other varieties. It is desired by the peddler and groceryman because of its thick husk, and it can be held over two days before it appears old or wilted. It is very productive, often bearing three marketable ears. Pkt., 10e; lb., 30c: 10 los., \$2.50.

BLACK MEXICAN-A rather short black variety, sweet and delicious. Splendid for home-garden. but not a market sort on account of color. Pkt., 10e; 1b., 30e; 10 1bs., \$2.50.

GOLDEN CREAM-Early and one of the best for the home-garden; it will become one of the most popular Sweet Corns ever used. Pkt., 10e; 1b., 30c; 10 lbs., \$2.50.

HOWLING MOB-In this corn we have the combination of earliness together with the large ears and fine flavor of the later varieties. The plant grows from four to five feet tall with heavy foliage and usually bears two fine ears to a stalk. The ears average eight inches in length and carry twelve to fourteen rows of large white kernels. Its flavor is sweet and rich and the husk is very heavy and long. Pkt., 10c; lb., 30c; 10 lbs., \$2.50. 


\section{Knox's Cucumbers}

Plant from February 15th to August 15th in hills 4 feet apart each way, dropping from 8 to 10 seeds per hill, and cover an inch deep. When they are about 5 inches high and danger of insects is past, thin out, leaving only four of the largest and healthiest plants to each hill. Cucumbers are extremely easy to grow and a few hills will produce an abundance for an average family. They are of very rapid growth, maturing from 6 to 8 weeks from date of planting. Ke $\in$ p the crop picked, when large enough for use. whether required or not, otherwise, if left to ripen, they will stop bearing.

DAVIS PERFECT-A very fine cucumber for market as well as the home garden, fine length, slimness, beautiful dark green color, transparent-like flesh with deliciously cool refreshing flavor, and crisp. Fruits 8 to 10 inches long. tapering at both ends, solid flesh, few seeds. It is one of the most popular among extra long white spine cucumbers. Ready for market in 65 days. Pkt., 10e; oz.. 15e; $1 / 4$ lb., 40e; $1 \mathrm{b.,} \$ 1.25$.

KLONDYKE-The finest strain of the white spine variety, and an excellent shipper. Very dark green, smooth. A very desirable size, being 7 to 8 inches long. Does not turn white or yellow with age. Very crisp and palatable. Excellent for pickling when young and the best sort for market. Pkt., 10e; oz., 15e; 1/4 lb., 30e; lor picklin

LONG GREEN IMPROVED-The very vigorous and productive vines bear uniformly slender, beautiful dark green fruits, 12 to 15 inches long. The bulk of the crop matures late. A fine sort of slicing and largely used for pickles fine for the home garden. Pkt., 10e; oz., 15e; 1/4 lb., 30c; 1 b., \$1.00.

WEST INDIA GHERKIN-This is a distinct, very small, oval, prickly fruited sort used exclusively for pickling. The fruit is 2 inches long and 1 inch in diameter and borne in abundance. The seed of this variety is slow to germinate. Pkt., 10e; and borne in abundance. The

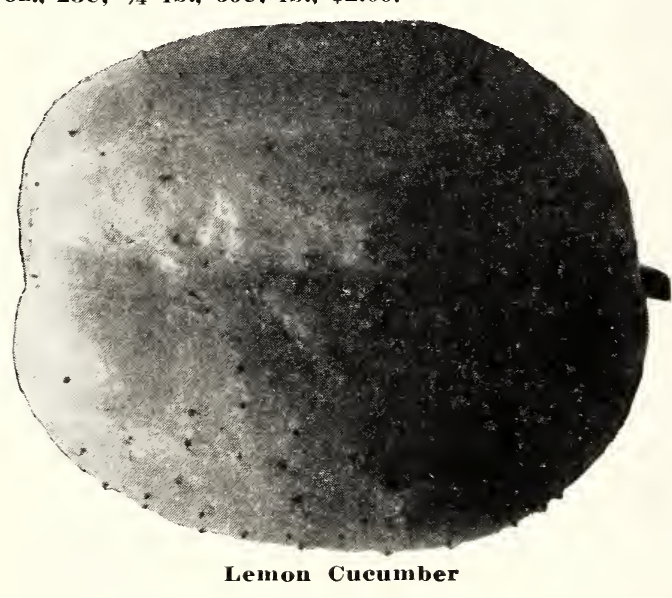

EGG PLANT

EARLY SHORT GREEN-This variety is known also as Early Frame. It is an early, bright green cucumber of medium size, very extensively used for slicing and pickling. The vines are very vigorous and productive. The fruits are straight a little smaller at the ends, bright green in color, shading lighter a the blossom end. The flesh is crisp and tender. The variety is extensively used for the home garden. Our stock is very superior. Pkt. 10e: oz., 15e; $1 / 4$ lb., 30e: lb., \$1.00.

LEMON CUCUMBER_Similar in shape to a lemon. The flesh is tender, crips and possesses a sweetness and flavor surpassing all other cucumbers. They are unexcelled for pickling. Pkt., 10e; oz., 20e; lb., \$1.50. BOSTON PICKLING-For pickling this variety is superior to all others. Its fruit is short, pointed at each end, bright green, uniform in size, very productive and of superior quality. Pkt., 10e; oz., 15e; $1 / 4$ lb., quality. Pkt.

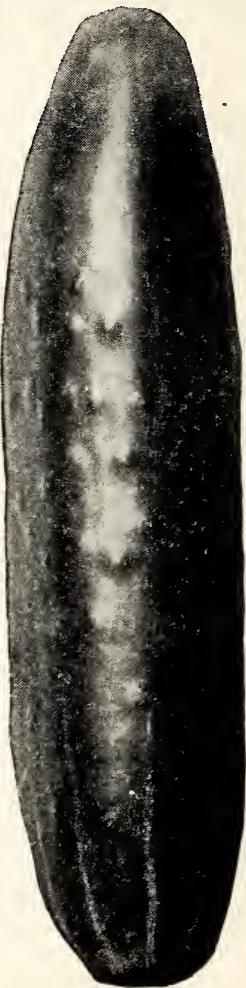

Davis Perfect
NEW YORK LMPROVED SPINELESS - A very excellent standard variety growing strong bushes, which are larger than the Black Beauty and better in that respect for keeping the "eggs" off the ground. The large dark purplish black fruits are heavy at blossom end and narrow toward the stem end. and are smonth and of fine quality. Pkt., 10e; oz., 50c; $1 / 4$ lb., \$1.50; $1 \mathrm{b.}$.\$5.00.

EARLY LONG PURPLE-An early variety with club-shaped dark purple fruits 6 to 8 inches long. Very productive and of fine quality. Pkt., 10e; oz., 50e; $1 / 4$ 1b., \$1.50; 1 b., \$5.00.

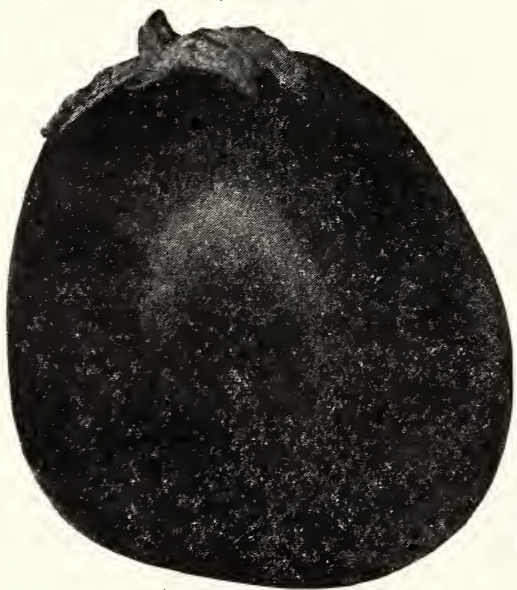

IMPROVED WHITE SPINE-The market gardener's favorite for field culture. It is one of the best sorts for the table, on account of its color which seldom changes to a yellow when kept after being picked. Pkt., 10e; oz. 15e; 1/4 lb., 30c; lb., \$1.00.

\section{ENDIVE}

BROAD-IEAVED BATAVIAN-Rosette often 16 inches in diameter with broad, twisted, or waved green leaves and thick white midribs. Makes a fine "head" and blanches easily. The most exclusively grown variety. Pkt., 10e; oz., 15e; $1 / 4$ lb. 30e; lb., \$1.00.

\section{BLACIK BEA UTY}

BLACK BEAUTY-It is preferred by growers for the early market because it matures marketable size earlier than any other variety, and because the fruit is dar kcolored when quite young and uniformly over the entire surface. It is entirely free from spines. It is popular because it is a moneymaker. Pkt., 10c; oz., 50e; $1 / 4$ lb., \$1.50; lb., \$5.00.

GRFEN CURLED - A hardy variety forming a rosette 16 to 18 inches across, with very curly leaves and rosy colored midribs. Fine for an autumn crop. Pkt., 10e; oz., 15e; 1/4 1b., 30e; Ib., \$1.00.

\section{DANDELION}

Furnishes our earliest and most healthful crop of spring greens. Sow the seed as early as the weather will allow, in good, well-enriched soil, and in rows a foot apart; cover them only $1 / 4$ of an a foot apart; cover them only $1 / 4$ of an above them. The plants should be thinned to stand 2 to 3 inches apart in the rows, that the roots may grow large and solid thus saving much time in trimming them. time in trimming them. An ounce of

pound will sow an acre. The best variety. Pkt., 10c. 


\section{KOHL RABI}

EXTRA EARLY VIENNA-A curious vegetable in appearance half-way between a Turnip and a Cabbage with a turnip-like swelling of the stems above the ground, which, while young and tender has a delicious Cauliflower flavor and very appetizing and pleasant. Very easily grown, requiring only such care as will make a Turnip or Cabbage do well. It is cooked much the same as Cauliflower do well. It is cooked much the same as Cauliflower and served with pepper, butter and salt. It is
certainly most delicious. Pkt., 10c; oz., 20c; $1 / 4$ lb., 60e; $1 \mathrm{~b}$. \$2.00.

\section{GARLIC}

Used for flavoring. The bulbs are set out like onion sets about 4 inches apart in the row, and covered 1 inch deep. When tops die down take up the bulbs and dry in a shady place. Bulbs only. Lb., 15e.

\section{MUSHROOMS}

LMPROVED ENGLISH SPAWN-Is grown by special culture from large perfect heads and then special culture from large perfect heads and then
pressed into bricks of about $1 \frac{1}{2}$ lbs. Each 50e: 10 pressed into
bricks, $\$ \mathbf{\$ 4 . 5 0}$.

\section{MUSTARD}

Sow in spring as early as possible in drills 18 inches apart, covering one-half inch. Water freely. Sow every few weeks for succession. In the South it may be sown in the fall.

CHINESE BROAD LEAVED - Leaves twice the size of ordinary mustard. The flavor is sweet and pungent, and it is very easily prepared for table use. Pkt., 10e: oz., 15e; 1/4 lb., 30c; lb., 85c.

WHITE ENGLISH-Leaves rather small, smooth and deeply cut; of a medium dark green color. A very rapid grower and the leaves when young are mild and tender. Pkt., 10e; oz.. 15e; $1 / 4$ lb.. 30e; Ib., 85e.

GIANT SOUTHEIRN CURLED-Large leaves often measure 14 inches; ready for use in about six weeks after sowing. Leaves boiled like spinach. Pkt., 10c; oz., 15e; $1 / 4$ lb., 30c; lb., 85e.

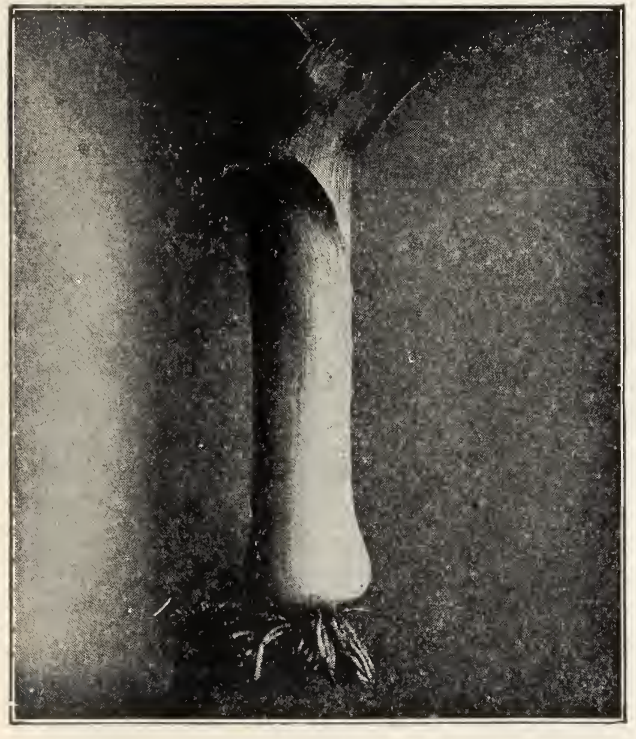

Leek

\section{LEEK}

A MERICAN FLAG-A very fine, early pruductive variety: a strong. quick grower of mild flavor. The stems are 2 inches in diameter and easily blanch as high as 10 inches from the root. This is an excellent sort for fall and early winter sowing. Pkt., 10c; oz., 20e; 1/4 lb., 60e; 1b., \$2.00.

\section{HERBS}

Pkt., 10c each

Anise-for garnishing, cordials and flavoring.

Basil, Sweet-The leaves and tops of the shoots are used for highly seasoned soups, stews and sauces: a leaf or two is sometimes placed in salads.

Borage-Excellent for bees. The leaves are used in salads, or boiled as Spinach; the flowers are aromatic and used in cool drinks.

Caraway-The aromatic seeds are used in confectionery, cakes and medicine.

Catnip-Used for seasoning, and also grown as a bee food.

Coriander-For garnishing; the seeds are aromatic and useful for flavoring.

Dill-The aromatic seeds are used in pickles, preserves, soups and sauces.

Florence Fennel-An excellent salad plant and is also boiled. The flavor is sweet, spicy and distinct.

Fennel, Sweet-The leaves boiled enter into fish sauces; beautiful for garnishing.

Lavender-A popular, aromatic Herb, emitting a delightful perfume.

Marjoram, Sweet-The leaves and shoots are used for seasoning.

Rosemary-The aromatic leaves are used for seasoning.

Sage-The leaves are used in dressing and in sauces.

Savory, Summer-Used for seasoning and flavoring soups and dressing.

Savory, Winter-A hardy perennial; the leaves are used for flavoring.

Thyme, Broad-leaved-The leaves are dried for seasoning.

\section{KALE or BORECOLE}

TALL GREFN SCOTCH CURLED-Very similar to the Dwarf Green excepting that leaves are a brighter green, a little coarser, and are borne at the top of a stalk two feet from the ground. It is of good quality and so hardy that a light frost improves rather than injures it. Pkt. 10c: oz. 15e; $1 / 4$ ib., 40c; 1 b., $\$ 1.25$.

JERSEY OR COW KALE - A robust-growing sort, often 6 or 8 feet high; grown largely for stock and chicken-feed. Pkt., 10c; oz., 15e; 1/4 ib., 35e; 11 .. $\$ 1.00$.

DWARF GREEN CURLED SCOTCH-Known in the East as "Sprouts," and sometimes confused with Brussels Sprouts, which it does not in the least resemble. The cultivation is about the same as for cabbages. Four ounces of seed will sow 300 feet of row. Rarely exceeds 18 inches in height. but spreads under good cultivation to 3 feet in diameter: leaves beautifully curled and bright green; very hardy. and will stand out where temperature does not fall below zero. Pkt.. where temperature does not fall b

\section{OKRA or GUMBO}

The pods of this vegetable are very highly esteemed in the South for use in soups and stews and should be more widely used in the North. Plant in good, warm. rich soil after danger from Plant in good, warm. rich soil after danger from plants being one foot apart in row. The pods must be used when young.

PERIKINS, MAMMOTH-Plants about three feet tall: pods four to five inches long, of handsome apnearance, soft green in color, tender and of good nuality. remaining tender until nearly full size. Pkt., 10e; oz., 15e; $1 / 4$ lb., 30e; lb., 75e.

WHITE VELVET-Plants three feet tall and of handsome appearance; pods four or five inches long. round and of a white velvety appearance, quality is excellent and the pods remain in their prime for a long time. Pkt., loc; oz., 15e: $1 / 4$ lb. prime for a 


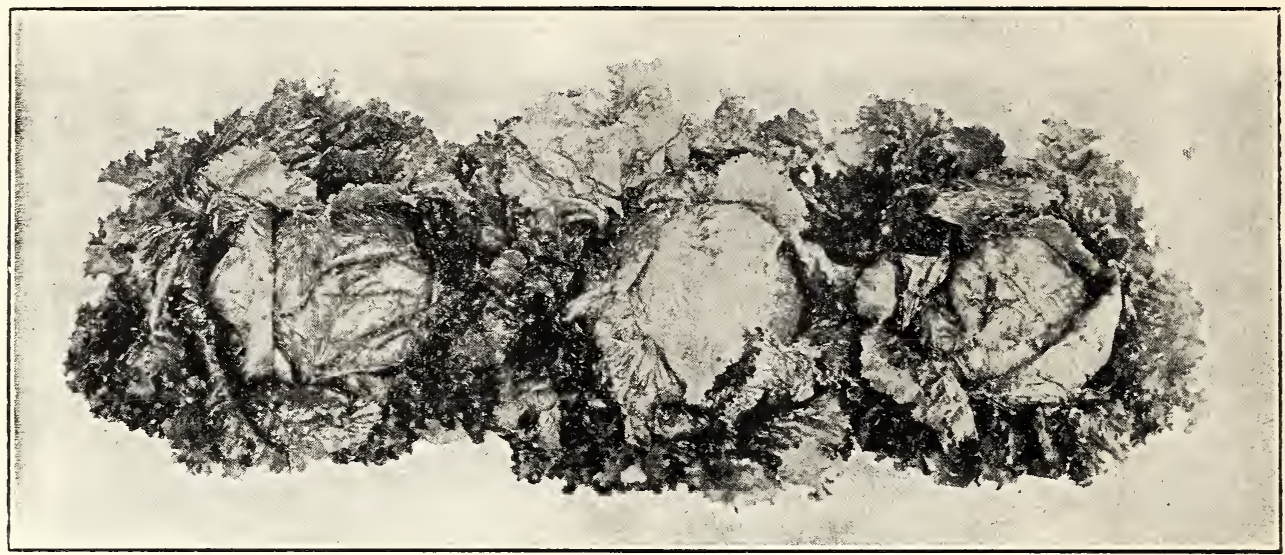

\section{New York Wonderful or Los Angeles \\ Knox's Lettuce}

The ground for lettuce should be prepared the same as celery, that is, trenches should be dug about 5 inches deep and 2 feet apart. If seed is used it should be drilled 1 inch deep along the edges and both sides of the trench. When the plants are about 1 inch high they should be thinned to 12 inches apart, and the plants that are pulled can be transplanted to other parts of the garden. When irrigating, run the water at the bottom of the trenches, let it stand and sub-irrigate. Do not under any circumstances allow the water to cover the plants, as it wiil cause Stem Rot.

Lettuce, like Cauliflower and Cabbage, will not head solid during the hot summer months, although the Iceberg variety will grow and form loose heads fit for family use and should be planted from May ist to Julv 1st. Los Angeles lettuce, which is the best winter and spring solid heading variety, can be planted from August 15th to April 1st. Excessive heat will sunburn lettuce on the inside of the heads and cause them to rot.

ICEBERG-A sure and hard-heading variety, the medium-sized plants, with strong midrib, producing large heads Outer leaves light green, curly and finely fringed. Hearts a beautiful white, crisp Use this and tender. Use this sort during the hot summ

CALIF. CREAM BUTTER-A crisp tender, richly flavored variety, forming large heads of a beautiful creamy color: medium early, and stands summer heat remarkably well. Pkt., 10c; o\%., 20c; 1/4 lb., 50c; 1 b., \$1.50.

HANSON - A desirable, large-heading summer flavored variety, forming large heads of a beautiful creamy color; medium early. and stands summer heat remarkably well. Pkt., 10c; oz., 15e; 1/4 lb., 35c; 1 b. \$1.00.

BIG BOSTON-This fine variety is extremely popllar for outdoor culture in the spring and fall, and

NEW YORK OR LOS ANGELES-(Known as California Dark Iceberg by some market gardeners and shippers.) This is the variety used almost exclusivey in our markets and is grown on an immense scale.

The variety is deep green, but when prepared for the table the head is almost white and very crisp. It thrives in cool weather and is not recommended for the house garden in midsummer. The proper name for the variety is NEW YORK, under which name it was introduced into America years ago and in ordering, customers should use this name to get the true variety. We have an excellent and highly developed strain of it which is used in large quantities by the big shippers. quantities by culture, sow the seed thinly and thin the plants when in the fourth leaf to at when in the fourth lear to twit will seem like a wide distance, but to make solid heads, the plants need plenty of room. The soil should be well fertilized and irrigated pkt, 10eg on. and irrigated. Pkt., 10c; oz. \$2.25.

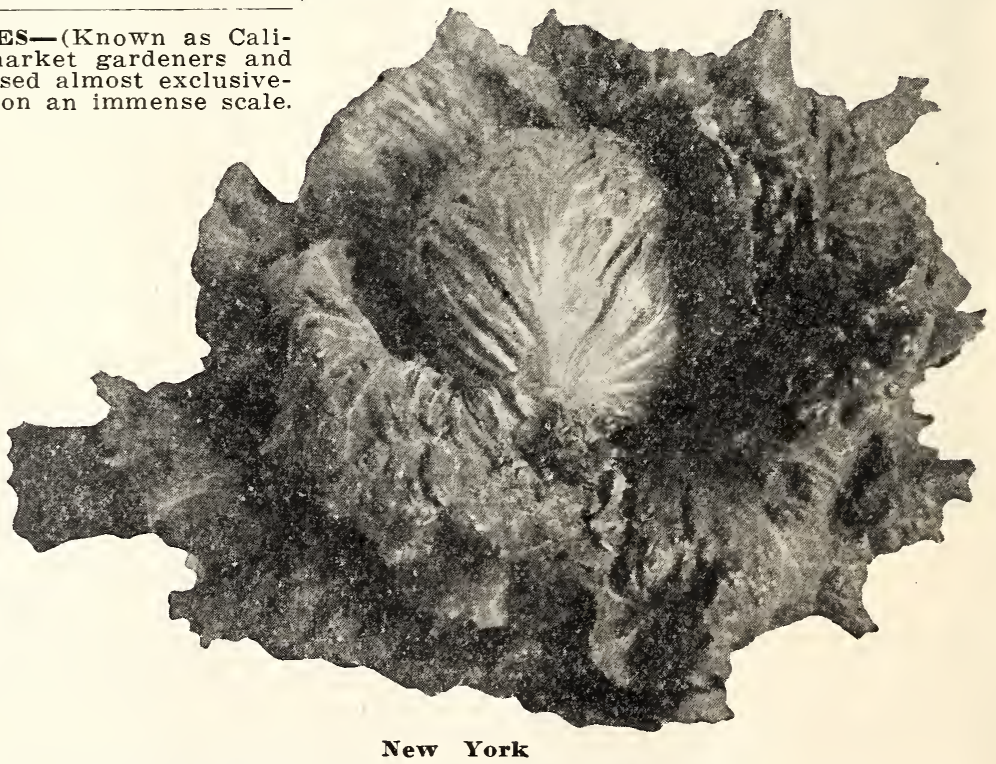

for coldframe forcing. The plants are large, very hardy, and vigorous. The broad leaves are comparatively smooth, wavy at the edge, thin and crisp. We recommend it as one of the best homegarden lettuces on account of its easy culture. Pkt., 10c; oz., 20c; $1 / 4$ lb., 50c; 1 b., \$1.50.

PARIS WHITE COS-Cos lettuce is of conical form, with elongated head. Outer coloring is yellowish green. Very crisp and sweet. Pkt., 10c; oz., 20c: $1 / 4$ lb., 50c; 1b., \$1.50.

EAIRY CURLED SIMPSON - Forms a compact mass of yellowish green, curly leaves; earlier than head lettuce; grown in cold-frames and open ground. Pkt., 10c; oz., 20c; 1/4 lb., 50c; lb., \$1.50.

EARLY PRIZE-HEAD-Leaves finely curled and crimped, bright green tinged with brownish red, crisp and sweet. Pkt., 10c; oz., 20c; 1/4 1b., 50c; $1 b$. $\$ 1.50$. 


\section{MUSK MELONS}

PERSIAN MUSKMELON-This is a large melon, from 8 to 10 inches in diameter, and is heavy for its size. The melons are heavily netted and are globular. Its color is bright orange. The flavor is different from other melons and comes out delightfully when the melons are well ripened. Do not try to eat them until fully ripe. Many persons prefer Persian melons before all other sorts. Pkt., 10e; oz., 20e; 1/4 1b., 60c; Ib., \$2.00.

HONEY DEW-The rind is a dull white when ripe. Part of the melon shows slight checks in the rind like a tendency to net. This appears. when the melon is ready to pick. This melon is 6-7 inches through and about 8 inches long. Pkt.. 10e; oz., 15e; $1 / 4$ lb., 35e; lb., \$1.25.

POLLOCK-10-25--(Ten-twenty-five). This is a new main crop variety ripening at the same time as Rocky Ford. The melons are nearly round or slightly oval with no ribhing and densely netted all over the melon. Each $\mathrm{m}$ son is 5 to 6 inches long-a nice commercial size. The seed cavity is small and the flesh thick. Flavor is excelle $\mathrm{nt}$ and sweet, This is the standard muskmelon for the market and is excellent for the home garden. It is a newer selection from Pollock 25 and is consichered a slioht improvemant over that splendid sort. Pkt., 10e; oz., 15e; 1/4 1b., 30c: Ib., \$1.00.

HEARTS OF GOLD-It is an early pink flesh variety, with a moderate amount of netting and fairly distinct ribs. While an ex cellent shipping melon it is also equally wel for both market gardeners and home use as it remains edible for several days. The melons weigh about one and one-half pounds each; the seed cavity is remarkably small and the flesh is sweet and spicy. Pkt. 10c; oz. 15e; 1/4 Ih., 30c; 1/2 Ib., 6.5e; lb., \$1.00.

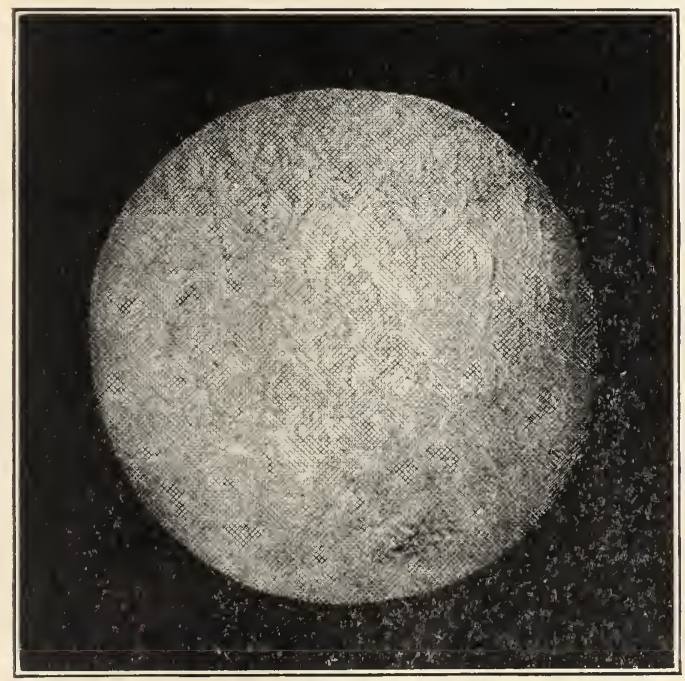

HONEY BALL MELON - The sweetest of the sweet and the most delicious of all melons. Is very prolific, a little larger than Rocky Ford, with flesh like Honey Dew. Melons are uniform in size and show considerable netting. Honey Ball matures ni about 105 days from planting the seed. For marketing at a distance, it has no equal for the melons stay firm and keep well in storage. It canmelons stay firm and keep well in storage. It can tests and reports Honey Ball possesses charactertics that make it one of the finest melons ever offered to the grower, the shipper and the consumer. It is a cross between the California Honey Dew Casaba and the Texas Cannon Ball. Pkt., 10c oz., 20c: $1 / 4$ lb., 45c: $1 \mathrm{b.,} \$ 1.50$.

IMPROVED HYBRID CASABA-This is a large casaba, with a wonderfully sweet flavor; very prolific; extremely popular with the growers because of its heavy demand by the housewife; thick flesh of excellent quality. Pkt., 10c; oz., 15e; 1/s lb., 35c: Ib., \$1.25.
TIP TOP-A well known very productive market sort in some sections. The fruits are large, nearly round, slightly ribbed and fairly well covered with shallow netting. The skin is light yellow when the fruit is mature. The flesh is deep yellow, rich, and highly flavored. Pkt., 10c; oz., 15e; 1/4 lb, 40c; 1b., \$1.25.

ROCKY FORD or NETTED GEM-This is a medium-early variety with vigorous and productive vines. Fruits are oval, very slightly ribbed, and densely covered with fine netting. The flesh is thick. green. sweet, and highly flavored. Pkt., 10c; ok., 15e; 1/4 lb., 30c; 1b.. \$1.00.

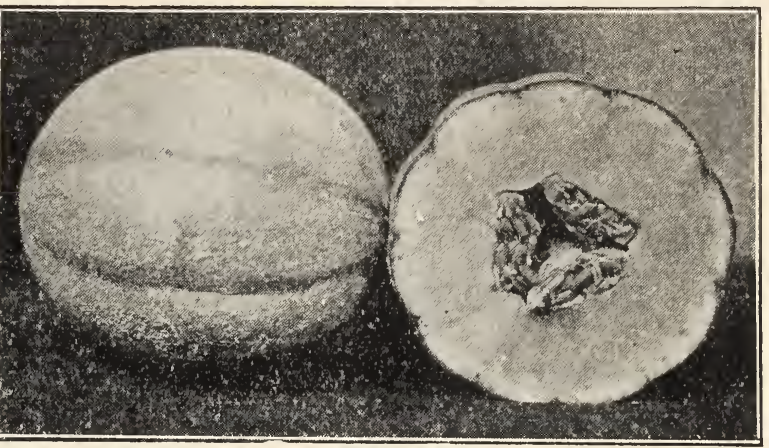

Tip Top

GOLDEN BEAUTY CASABA-One of the best casabas. Begins to ripen in July and continues ripening and bearing all summer and fall until frost comes. The later fruit can be stored in a cool house or cellar and will ripen slowly. Golden Beauty is bright yellow about globular, with wrinkled skin and slightly pointed at the stem ends. The flesh is fine-grained pure white, very thick and of an extra-good flavor. Pkt., 10c; oz., 1.5e: $1 / 4$ lb., 30c; lb., \$1.00.

ROCKY FORD GOLD LINED-A perfect shipper due to the hard netted rind. Gets its name from the yellow tinge around the seed cavity. Has best flavor of all Rocky Fords. Pkt., 10c; oz., 15e; 1/4 1b., 30c; 1b., \$1.00.

HALE:S BEST-An extra early salmon tint of remarkable flavor. The seed cavity is small and the attractive salmon tinted flesh is firm. Melons are oblong, well netted and very attractive. It is ten days to two weeks earlier than other shipping varieties and vields wonderfully well. Quite a few of them are being planted in the Imperial Valley for shipping purposes. Pkt., 10e; oz., 1\%e; 1/1 ll.., 30e: $11 \mathrm{l}$. .\$1.00; postpaid.

\section{ONION SETS}

The earliest onions are grown from sets planted in September. This brings them in the market in February and March, when prices are highest. About 250 lbs. of sets will plant one acre.

Prices subject to market Change. Write for Prices on Iarger quantities.

For the home garden no vegetable is so valuable as the onion, and for this purpose it is better to plant sets because they are ready for the table six weeks after planting. Set them three inches apart in rows six inches apart. When ready for use, take up everv other one as needed, allowing the balance to grow to mature size. One pound of sets will plant about fifty feet of row. Lb.. 25e; 10 lbs., \$2.00. Prepaid.

\section{SILVER-SKIN SETS}

Sets from White Portugal or silver-skin seed. Make large silvery white onions of fine quality when mature. Plant a few also for early green onions. Ih.. 25e; 10 lbs., \$2.00. Prepaid.

\section{PEANUTS}

While it is not generally known, nevertheless Peanuts do well in many parts of California. They should be planted about April in rows and can be so grown between trees or vines. We carry the Japan Pearuts which are most used. The soil must be very sandy. Lb.. 25c. 


\section{Watermelon}

A light, sandy soil, with good exposure to the sun, is the best for watermelons. It should be prepared deep, but receive shallow cultivation. Hoe of ten and thoroughly. To get good, strong vines early in the season form large, well-drained hills of earth, made very rich, about 8 feet apart. In these plant the seed as soon as the ground is warm and dry, dropping 6 to 10 seeds to the hill. Protect the young plants from insects. One oz. to 30 hills, 3 lbs. to the acre. When the plants are about 4 inches high thin out, leaving only four of the strongest plants to each hill.

TOM WATSON-An extra long melon of attractive appearance, uniform in shape and quality. The dark green rind is tough, but thin and easily withstands shipment to distant markets. The deep red flesh extends to within threefourths of an inch of the green rind, is crisp, melting and of finest flavor. The melon measures about 24 inches long and 12 inches in diameter and of ten attains a weight of from 50 to 60 pounds. It is very prolific, producing in great abundance the large, delicious fruits. Pkt., 10c; oz., 15c; $1 / 4$ lb., 30c; lb., $75 c$.

ANGELINO-This new variety of melon is coming to be a great favorite with shippers. Dark green with a bright red flesh and excellent flavor. It stands up well and sells easily. Seeds must be soaked a few hours before planting, otherwise they tend to rot. Pkt., wise they tend to rot. Pkt., 75e.

GYPSY OR GEORGIA RATTLESNAKE-An old standard sort that is very popular especially in the south. Very large, oblong, distinctly striped and mottled; flesh dark red and very sweet. Skin firm and solid, making it a good shipping sort. Pkt., 10e; oz., 15e; 1/4 1b., 30c; 1b., 75c.

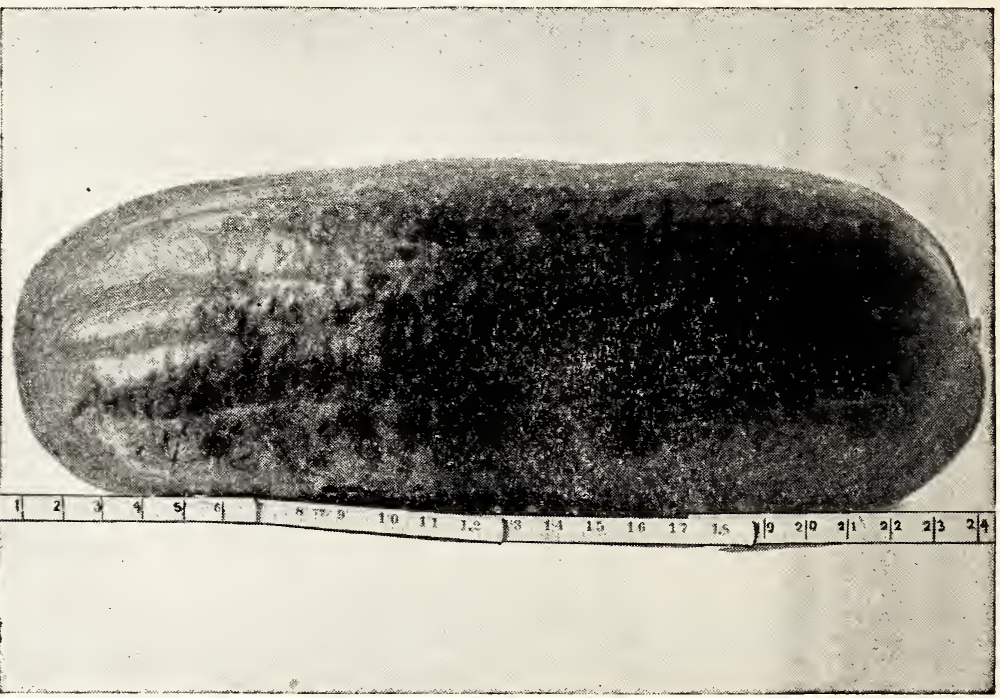

Tom Watson

FLORIDA FAVORITE-A splendid long melon of very large size and excellent quality. Dark green skin mottled and striped with lighter green; thin skin mottled and striped with lighter green; thin
but firm rind. Flesh is very deep red, sweet, and tender. Vines vigorous and productive. A good keeper. Pkt., 10c; oz., 15e; 1/4 1b., 30c; 1b., 75c.

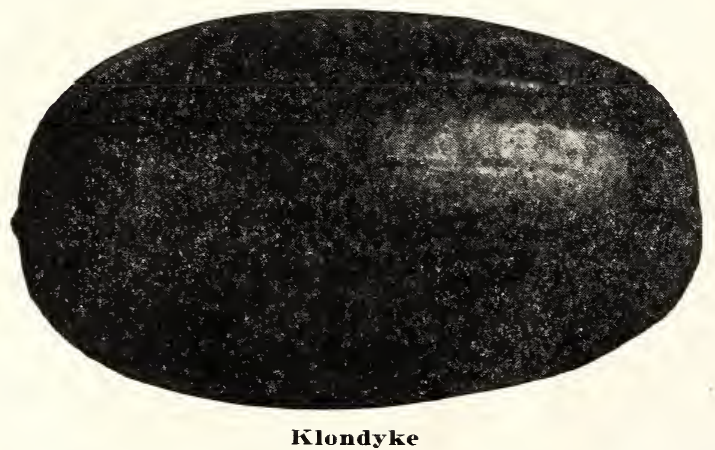

EXCEL-To the grower and shipper who wants a large melon the Excel fills the bill It is oblong dark green with a suspicion of a stripe, and will average $35 \mathrm{lbs}$. and is of excellent flavor. It is a good shipper and has maintained its popularity for many years. Our seed is from our own growing many years. Our seed is from our own growing and is tr.

BI.ACK SEEDED ANGELINO-Many prefer a melon with black seed. This variety has all of the good points of Angelino-bright red flesh, sweetness and size. l'kt., 10c; oz., 15c; 1/4 lb, 30c; lb., 75c.

CHILIAN, WHITE-SEEDED-Th is melon in some sections of the state is known as the CannonBall Melon on account of its shape. The rind is thin and the flesh is deep red and deliciously sweet. Pkt., 10c; oz., 15c; 1/4 lb., 30c; lb., 75c.

Our position as MARKE' GARDENERS' SEEDS$M E N$ is well and favorably known both at home and throughout the country. Our pre-eminent standing in this line of the Seed Business has been long; estublished. The Market Gardener, when he plants KNOX'S SEEDS, may therefore feel reasonably sure that he is planting the best seeds obtainable.

KLONDYKE-Has bright red flesh, firm, and exceptionally sweet. Skin too thin to make a shipping melon, but for the garden there is no melon quite the same. Pkt., 10c; oz., 20c; 1/4 lb., 50c; lb., \$1.50.

BLACK-SEEDED CHILIAN-This is a melon of the round type whose flesh is bright red and the flavor remarkably fine is very thin and brittle and the skin colored a is very thin and brittle and the skin colored a a fine type of melon recommended for the home garden. Pkt., 10e; oz., 15e; 1/4 lb., 30e; lb., 75e.

KLECKLEY'S SWEET-Very productive. The fruit is oblong. color dark green, flesh deep red, stringless, solid and very sweet; with but few seeds set near the rind. Pkt., 10c; oz., 15c; 1/4 1b., 30c; lb. 75c.

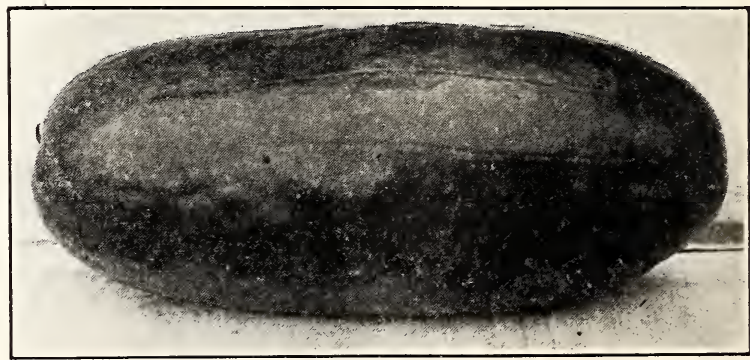

Kleckley Sweet 


\section{Knox's Selected Onions}

Onions are extremely hardy and will grow in any soil. No special knowledge or care is required, providing the soil is kept loose, and naturally onions. like anything else, will do better in good rich soil well drained. For extra early onions the seed should be sown in beds from August 1 st to October 1st. Transplant when they are as large as lead pencils 5 inches apart, in rows 15 inches apart during December and January, as the plants will be large enough by that time.

California Early Red is the earliest onion, maturing in May, the yellow, white and brown in June, and the Italian Red in July. A large percentage of the onions are grown along the rivers on bottom land and the seed is sown in December and January drilled in rows 16 to 18 inches apart and later thinned tures during August and September. The brown and yeilow varieties are the ones most extensively planted. If mildew should attract onions, dusting with sulphur will prevent it if applied in time.

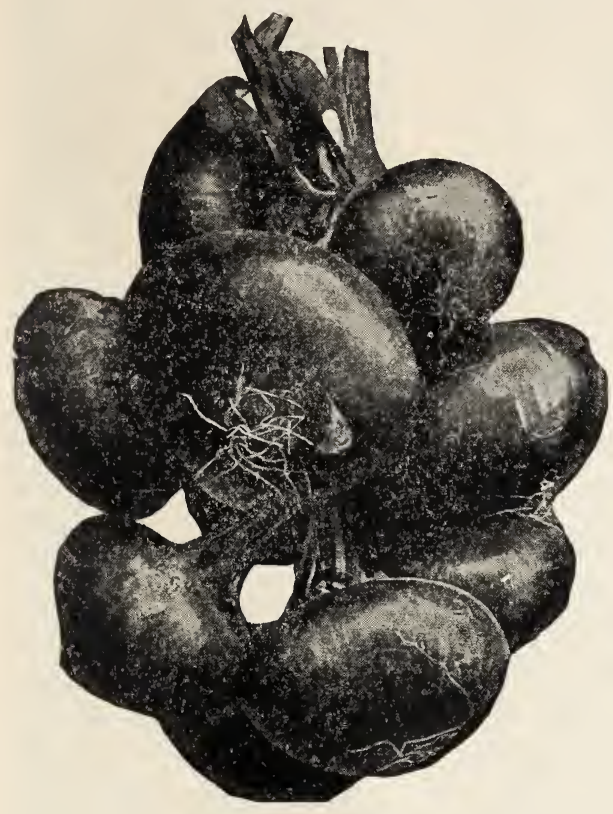

WHITE PORTUGAL Or SILVERSKIN-An extremely popular and fine white sort for sets or for use when young. Mature bulbs are of medium size. flattened globe shape, of mild flavor and beautiful silver white skin. Bulbs when young are nearly round and cannot be improved upon for table use, pickles or for salad. This is the finest flattened white onion for growing in the North. Pkt., 10c: oz., 20e; 1/4 lb.. 60e: \$2.00.

YELLOW DANVERS-A popular early flat variety that is excellent either for home use or main ety that is excellent either for thick bulbs, thin necks, thick brownish, yellow skin of good quality and mild. Uniform in size, sure in ripening and very productive. Pkt., 10e; oz., 15e; 1/4 lb., 40c; lb., \$1.30.

PRIZETAKER-A large Yellow Globe Onion of finest flavor handsome shape and enormous size. finest flavor, heigh many single onions having been raised to weigh three pounds or over. The Prizetaker grows alcolored skin. Pkt., 10c; oz., 20c; 1/4 lb., foc; $1 \mathrm{~b}$. $\$ 2.00$.

EARLY CAIIFORNIA RED-The best early red Onion to be had, as it is of good size, beautifu red. and as sweet as an apple. We recommend it for home use. Pkt., 10e; oz., 20c; 1/4 1b., 60e; lb., $\$ 2.00$.

SPANISH YELLOW-An exceptionally fine onion well adapted to warm climate. It is round, smooth and of very fine texture. The flavor is very mild. For shipping there is none better. A late variety maturing ahout the same time as the famons Australian Brown. Pkt., 10c; oz., 20c; 1/4 1b., 60e; lb. \$2.00.
ONG ITALIAN IRED-One acre planted in Italian Reds ill produce twice as many sacks as any other variety of nith and it can be harvested with one-half the labor, as It is not a good keeper, but its extreme sweetness favor with the consumer, making a ready sale

ARGE RED WETHERSFIELD-A very popular standard riety, with handsome large bright purplish red, somewhat lattened although quite thick, smooth, glossy, bulbs. Flesh nt. Medium early or main-crop sort, very productive, and ef the best keepers. Pkt., 10e; Uz., 20e; 1/4 Ih., 75e; 1h.

ELECTED YELLOW GLOBE DANVERS-Our strain of is fine main-crop onion has retained the small neck and ripening without yielding any of the good fire original strain. The bulbs, of medium creamy white, crisp, solid, and of mild and fine lib., \$1.30.

USTRALIAN BROWN - Exceeds any other onion in Aill produce a fine crop of hard, solid nions, even in unfortunate seasons. Of globe shape. The skin is light brown. flesh pure white and exceptionally kt., 10e; o\%., 15e; 1/4 lb., 35e; lb., 81.25.

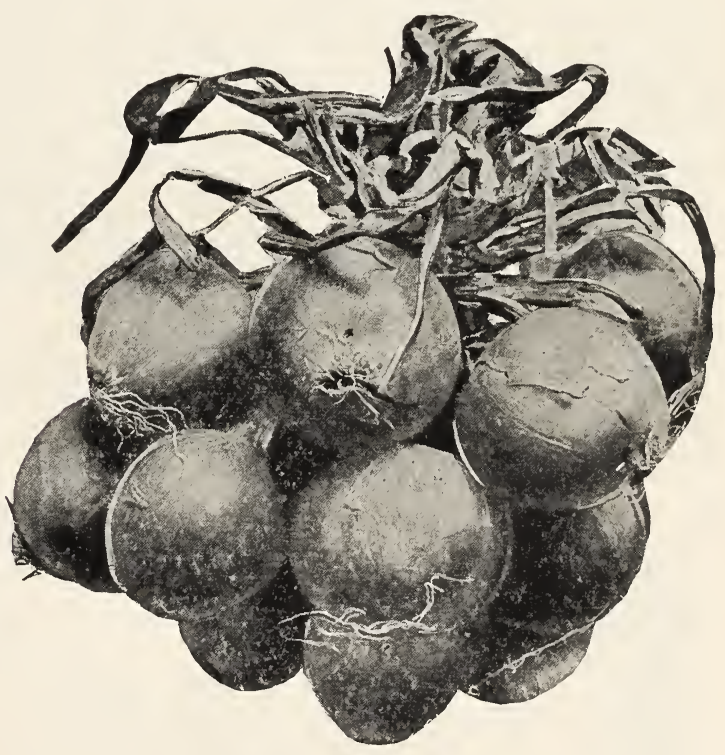

\section{SOUTHPORT WHITE GLOBE}

Differs from other Southports in color only; has all their general excellence. A favorite, owing to its beautiful color, shape and attractiveness. Southports command a big price on Eastern markets. The bulbs are of good size. splendid globe shape, pure white in color. Matures in 125 days. Pkt. 10e; oz., 20e; $1 / 4$ lb., 60e: $1 \mathrm{b.s}$ \$2.00. 


\section{Knox's Parsnip}

One ounce will sow 150 feet of row

Use a deep, rich sandy soil, although any deep, mellow, moderately rich soil will produce good roots. Sow as early in spring as possible, in rows which are $1 \frac{1}{2}$ feet apart, covering firmly with $1 / 2$ inch of fine soil. When plants are well up, thin to 2 or 3 inches apart in the row. Cultivate frequently. Parsnip seed is slow to germinate; sowing should be made early and soil pressed down firmly over seeds.

HOLLOW-CROWN-The roots are about 10 inches long, with swooth white skin, uniform in shape, tapering evenly from a heavy shoulder down to a small root, tender and of best quality. Pkt., 10c; oz., 15c; 1/4 lb., 30c; lb., 75c.

\section{SALSIFY OR VEGETABLE OYSTER}

Sow early in spring in drills 15 inches apart, and thin to 2 inches apart. Cultivate like carrots or parsnips. Its taste is similar to oysters when cooked, hence the name.

MAMMOTH SANDWICH ISLAND - The roots grow to double the size of the old sort, are very smooth, of superior quality, and delicate flavor. Pkt., 10c; oz., 20c; 1/4 lb., 65e; lb., \$2.25.

\section{RHUBARB OR PIE PLANT}

RHUBARB is very highly esteemed for use in pies, tarts, jelly and marmalade, and large quantities are sold in all markets every year. It is the first article of the season from the garden, and no private garden should be without it. Sow in drills one foot apart early in the spring. In the fall or next spring transplant three feet apart in deeply dug, very rich soil. Excellent for pies and tarts.

STRA WVBERR Y - A good size highly colored variety well adapted to San Joaquin Valley. Pkt. 10c; oz., \$1.25; $1 / 4$ lb., \$4.00; 1 b., \$15.00.

GIANT WINTER-It is undoubtedly a very productive and therefore very profitable variety. It is displayed at the market places in apple boxes, and the boxes are barely long enough to accommodate the large, thick stems that will average one-half pound each, often weighing more than a pound. It is remarkably early, bearing large stems within five months from planting the seed, and grows nearly the entire vear. The stems are so tender that they do not need peeling. Pkt., 10e; oz., Soc; $1 / 4$ lb., \$2.75; lb., \$10.00.

\section{RHUBARB ROOTS}

Set in January, they will furnish leaf stalks the following season. Large roots, each, 15c; 2 for 25c; doz., \$1.00, by mail, postpaid. By express at purchaser's expense, 25 for $\$ 1.50 ; 100$ for $\$ 5.25$.

\section{ROSELLE, THE SWEET CURRANT \\ JELLY PLANT}

ROSELLE makes a bright red jelly that both looks and tastes very much like currant jelly Roselle seed should be sown in April in the field where the plants are to remain, in rows 6 feet where the plants are to remain, in rows 6 feet grow rapidly and thrive in the interior valleys. In making jelly it is best to remove the seed pod. Pkt.. 10c: oz., 60c.

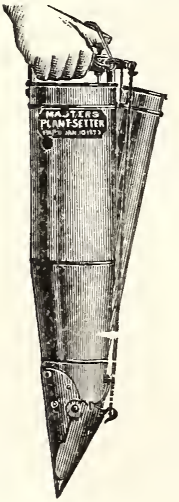

\section{MASTER'S PLANT SETTER}

\footnotetext{
Is a practical tool for transplanting cabbage, tomatoes, tobacco, sweet potatoes, caulifower peppers, egg plant, strawberries and all similar plants. Each plant is set, watered and covered in one set, waterThere is no stooping or bending There is no stooping or bending pleasant work. All of the hard, tedious labor of hand setting is done away with. One man will set more plants than three men can do by hand and do it better and easier. It does perfect work and every plant will grow. Each, \$6.50.
}

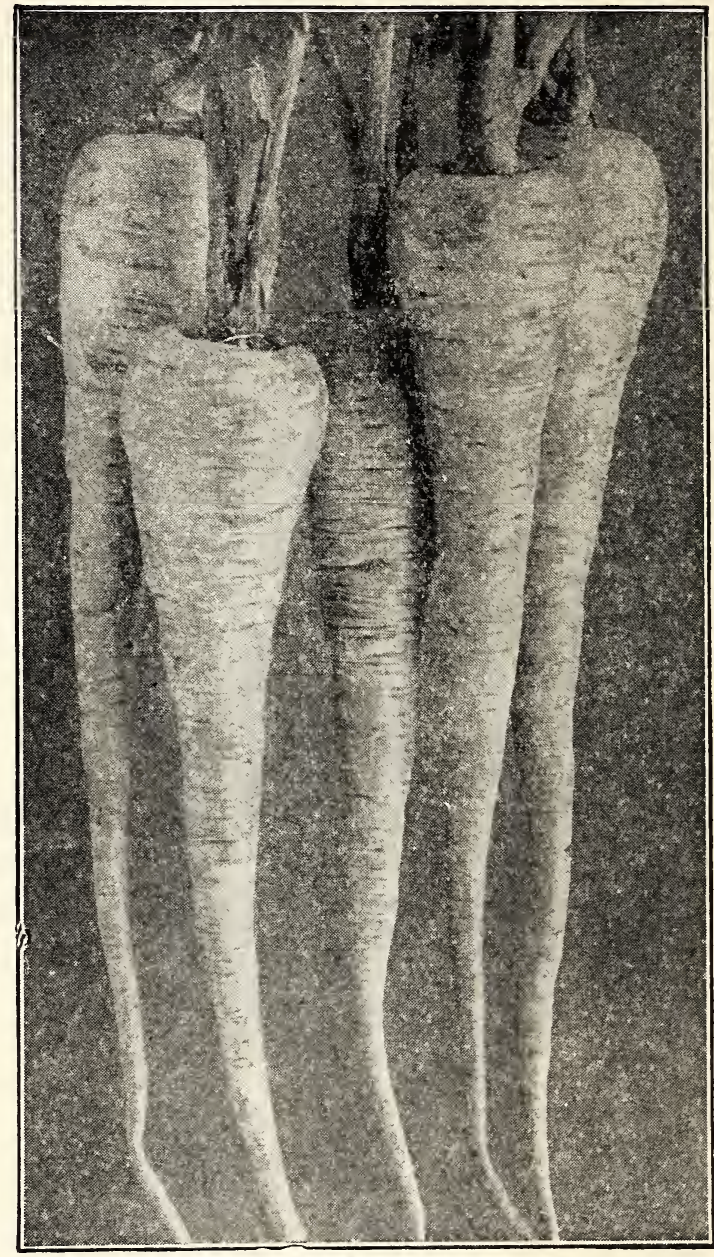

Hollow Crown

POTATO BEETLE - These striped yellow and black beetles appear in numbers in early sping and as soon as voung plants are up. 'They commence depositing egrs on the underside of leaves, meanwhile feeding upon the tender foliage. In about one week these hatch a horde of hungry larvae who destroy the foliage rapidly, attaining full size in from $2 \frac{1 / 2}{2}$ to 3 weeks. Remedies: Spraying or dusting with Arsenate of Lead, Paris Green.

CUCUMBER BEETLE-These striped black and yellow beetles appear in great numbers and attack the young plants as soon as up. Protect the vines with screens until they berin to run. Spray or dust with Bordeaux Mixture, Arsenate of Lead, Hammonds' Slug Shot, Tobacco Dust, covering underside of foliage.

APHIDES - Plant Lice, Grreen Fly. Bark Lice, etc., are minute insects feeding upon the sap in the tender parts of plants, both indoor and out. Can be successfully destroyed by the use of Black Leaf 40. A contact remedy is effective only when the poison touches the insect. Be sure to cover the underside of the leaves. 


\section{Knox's Improved Peas}

Write for Prices in large quantities

One pound will sow 60 feet of row. Light, moderately rich soil is best for this crop. Sowing of the first early variety should be made in October, and the other varieties for successive crops. Plant every two weeks until the first of April. Peas are sown in single or double rows, from 2 to 6 feet apart, according to the variety or height to which they attain. Have the rows of the dwarf varieties 2 feet apart, and those of the medium sorts from 3 to 4 feet apart, and the tall varieties from 5 to 6 ft. apart. Twenty-five pounds sold at 100-pound rates.

\section{EXTRA-EARLY VARIETIES}

ALASKA or EARLIEST OF ALL-A smooth pea, well suited for extra-early planting. Vine $21 / \mathrm{g}$ feet high, and carries usually 5 pods, each holding 6 or Peas. Will not rot in cold, wet ground; popular with canners. Pkt., 10e; 1b. 30c; 10 tbs., \$2.25.

\section{MEDIUM EARLY VARIETIES}

BLUE BANTAM - We expect this variety to become one of the most popular dwarf varieties for home and market-garden purposes. Pkt., 10c; lb. 30e; 10 lbs., \$2.25.

AMERICAN WONDER-Height, 10 inches. This variety heads the list of peas in flavor and quality. The vine bear a great abundance of good sized pods containing 5 to 8 large. exceedingly sweet-tender and well-flavored peas. This is the earliest of the dwarf wrinkled varieties, being nearly as early as the smooth sorts. This seed is medium sized, wrinkled and pale green. These peas are especially adapted to family use as they require no brush or Pkt. 10e: 1b.. 30c: 10 Itis.. \$2.25.

LITTLE MARVEL - An extremely valuable variety, especially suited to small home gardens and is also a splendid variety for early market gardening. It matures very early and produces large crops. The vines grow about 15 to 18 inches high. Pkt., 10c; lb., 30c: 10 lbs., \$2.25.

LAXTONIAN PEAS-The largest, the sweetest and most luscious of the second earlies. In fact it is exceptionally large. It is a dwarf, wrinkled variety that grows about 18 inches in height, a very prolific bearer, few if and producing niore. Laxtonian has an un usually superlative luscious sugar fla-

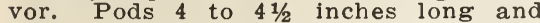
literally jammed with 8 to 10 peas, almost double in size of other dwarf peas. Pkt.. 10c: lb.. 30c: 2 lbs. 55c: peas. Pkt., 10e; lb.,

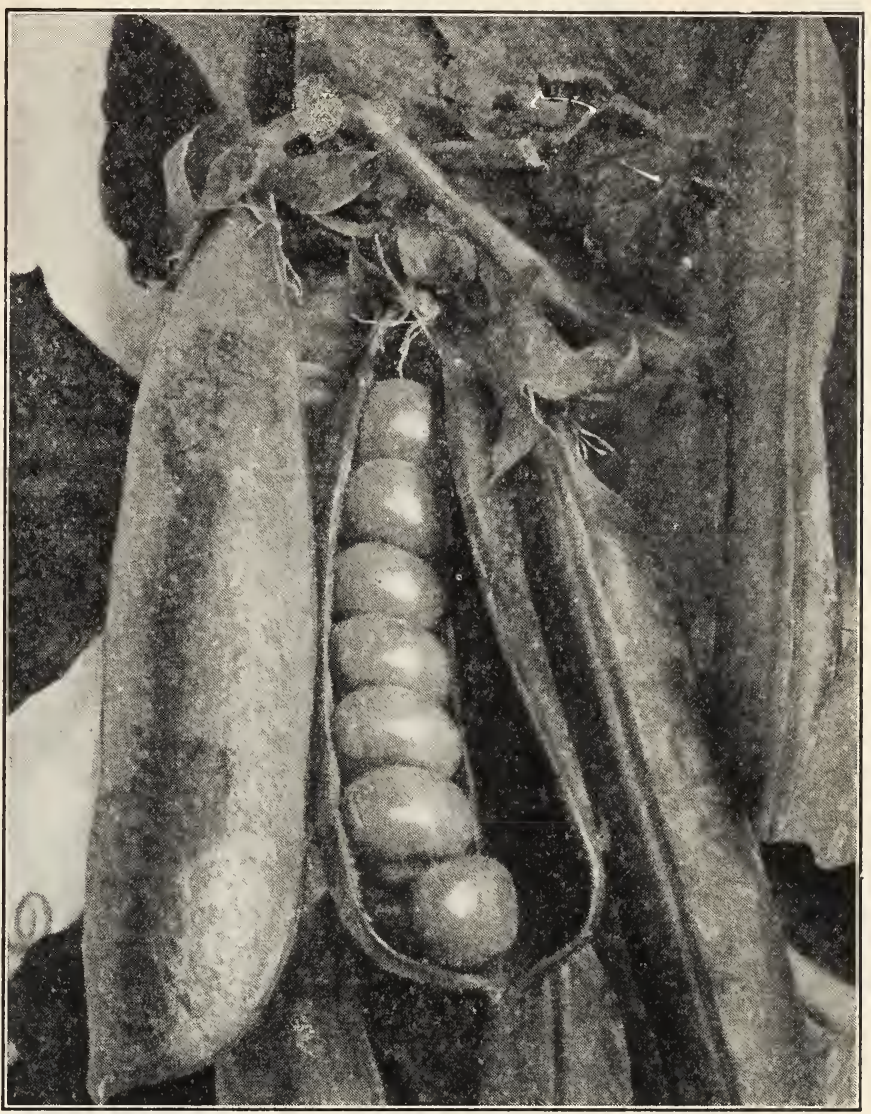

GRADUS, or PIROSPERITY-The most popular large-podded wrinkled sort. It matures just after the extra-early varieties, and produces a good crop of pods 4 inches long, providing it is planted on light warm, rich soil, but very disappointing under adverse conditions. The quality is excel-

Yorkshire Hero

lent. Height 3 feet. Pkt., 10c; 1b., 30c; 10 Ibs., 2.25

THOMAS LAXTON-A fine, early, tall variety, similar to Gradus, but more hardy and not quite so early. It is also a little darker in color and has large blunt pods that fill well with has large, blunt pods that fill well with Peas

\section{Main and Late Crop Peas}

ALAMEDA SWEET, Or YORIKSHIRE HERO-F or the market grower, this variety is without a peer. A main-crop Pea, producing long, round pods, closely filled with large, wrinkled, tender Pods, of good quality. Pkt., 10e; 1b., 30c; 10 lbs., \$2.25.

IMPROVED STRATAGEM-An improved variety comprising all the good qualities of the old Strataom highly developed; the pods are of immense size, well filled with dark green Peas of the finest quality; a heavy cropper; 2 feet high. Pkt., 10e; lb., 30e; 10 lbs., \$2.25.

TELEPHONE-Immensely productive and of the finest quality. Vines very strong, averaging 18 to 20 pods per stalk. The pods are of large size, containing 6 to 7 Peas each, which are of a pale green, and are closely packed in the pod, and of most delicious favor. The Telephone is decidedly a popular variety for the market gardener, the number of pods on a vine making easy picking and the large size filling the basket very quickly. For many years it has been the standard maincrop variety, 4 feet. Pkt., 10c; 1b., 30c; 10 lbs.,

ALDERMAN-This is a very large-podded Pea, very robust and vigorous, producing pods of the largest size. The pods are even larger and longer than the average large-podded sorts, and are well filled with large Peas of most excellent flavor. In habit, the vines are strong and branching, bearing rich, deep green, straight, handsome pods, pointed at the end. This variety belongs to the tall-growing main-crop class of Peas. The vines are from $31 / 2$ to 4 feet in height. A point of superiority which must not be overlooked is the unusual flavor and quality of the Peas. As it is true of most wrinkled varieties they are delicious, but the Allerman is of a quality surpassing many of the derman is of a quality surpassing many of the others. Be sure to include Alderman Pe 


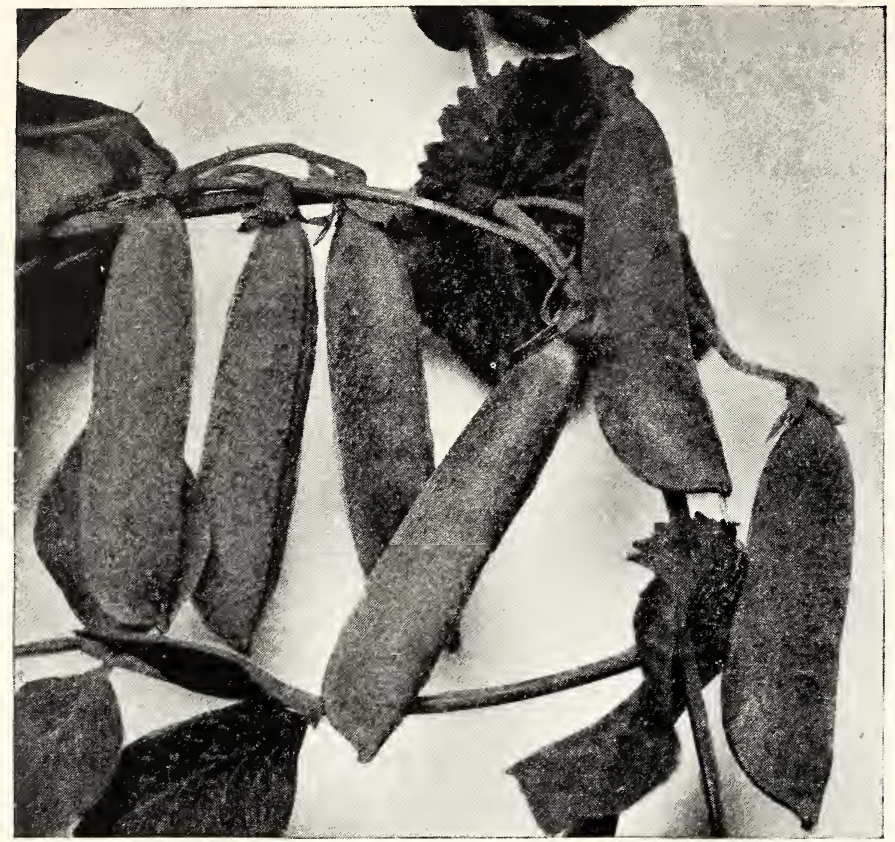

\section{Peas}

(Continued)

HUNDREDFOLD - Used for home and market gardening. Vine is 18 in. dark, medium coarse. The pod is $3 \frac{3}{4}$ in., pointed, dark, single. The season is 62 days from planting to table and 80 days from planting to maturity. The seed is large, yellow and green, flattish and wrinkled. Pkt., 10e; 1b., 30e; 10 lbs., \$2.25.

MELTING SUGAR, EDIBLE PODSHeight 4 to 5 feet Well deserves its name. Should be cooked and eaten pods and all, the same as Wax Beans. Pods are stringless and when cooked are tender, sweet and sugary-a great improvement over the ordinary Sugar Pea. A few rows of this variety should be in every home garden. Pkt., 10e: $1 / 2$ lb., 20e; lb., 35e, postpaid; 10 lbs., $\$ 3.00$.

\section{Knox's Peppers}

For early peppers sow the seed in hot beds ill December and January. Transplant as soon as weather and soil in your locality will permit, 18 inches apart in rows 30 inches apart. For later crop you may also sow seed in February and March. Pepper seed germinates slowly and needs the heat of a hot bed to germinate in these months. In most cases it is advisable and sometimes cheaper to buy plants already started if only a few are wanted. The very same rule applies to the planting and growing of egg plant. These two varieties of vegetables are rather hard to start frum seed, but when once transplanted they are ex-

LARGE HELL or BULL NOSE-The plants are vigorous, about 2 feet high, compact and productive, ripening their crop uniformly and early. Fruits are large, about 3 inches long and 3 inches across the top. with very thick, mild flesh of excellent quality. The color is deep green when young. glossy scarlet-crimson when ripe. Pkt., 10c; oz., 50e; 1/4 lb., \$1.50; Ib., \$5.00.

PIMIENTO - An excellent attractive and very productive variety. The fruits are medium sized, smooth and glossy green, becom ing red as they mature. The meat is thick and of a fine sweet flavor. The plants are vigorous and of medium height. This sort is largely used by canners, but is equally valuable for salads and for stuffing. Pkt., 10e oz., 45e; 1/4 Ib., \$1.25; Ib., \$4.50.

CHINESE GIANT - An exceedingly large red pepper. The plants are vigorous but stocky, 2 feet high, well-branched and thickly set with fruits. The monstrous fruits mature slightly later than Ruby King. are blocky in form, 4 to 5 inches broad at the top and of equal length, divided into four or more ridges, of a brilliant glossy scarlet, and mild in flavor. Pkt., 15e: \$1.25; Ib., \$4.50.

LONG IED CAYENNE-A red hot variety. The slender, tapering, twisted, pointed pods are pendent and average 3 inches in length diameter reducing from $1 / 2$ inch to the point. They are deep green when young, bright rea and very pungent when ripe. Plant is productive branching and with dark green foliage. Pkt., 10c; oz., 55e; 1/4 1b., \$1.50; 1 b., \$5.50.

RED CHILI - Small bright red Peppers, very hot and pungent. The pods generally used in making "Pepper Sauce" Pkt., 10c used in making "Pepper Sauce.

RUBY KING-Plants are about $2 \frac{1}{2}$ feet high, vigorous, compact, and very productive. The fruits are 4 to 5 inches long, of a deep green color when young and bright red when ripe. The shape is similar to Bull Nose but longer, slimmer, far more symmetrical, and more perfectly formed. Flesh is thick, mild and sweet. Pkt., 10c; oz., 50e; 1/4 lb., \$1.25 1b., \$5.00.

ANAHEIM CHILI-This Pepper is largely grown and is used dried for canning. It is long, 7 inches or so, medium-sized in width, and thick fleshed. The flavor is mild for a Chili Pepper, and one liked by Mexicans and Americans alike. Pkt., 10e; Oz., 55e; $1 / 4$ lb., \$1.50; 1 b., \$5.50.

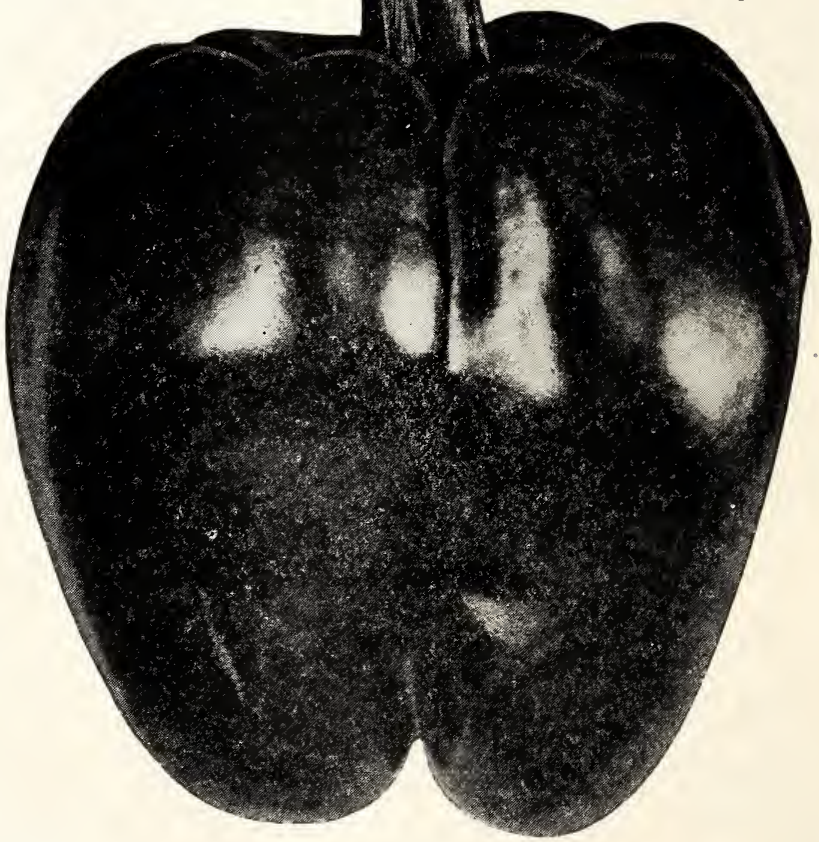

\section{PARSLEY}

CHAMPION MOSS CURLED - Leaves tender beautifully crimped, handsome bright green color. Pkt., 10e; oz., 15e; 1/4 lb., 30c; lb., \$1.00. leaves. Pkt., 10c; oz., 15e; 1/4 lb., 30c; Ib., \$1.00.

PLAIN-LEAVED-Much used in soups, etc., rather stronger in flavor than the other sorts. Pkt., 10e; oz., 15e; 1/4 lb., 30e; Ib., \$1.00.
FINE DOUBLED CURLED-Fine dwart; crimped 


\section{Knox's Pumpkins}

Pumpkins are frequently planted in connection with a crop of field corn, and if you grow corn you may just as well grow pumpkins. They will grow best in soil kept moist by the dry farming method, as too much moisture will kill them. Plant the seed in open ground, after the danger of frost is over, in hills 8 feet apart each way, arop from 8 to 10 seeds per hill and when the plants are about 5 inches higi and danger of insect pests is past, thin to 3 or 4 of the healthiest plants. If irrigation is needed, run the water in ditches about 18 inches from the hill. Do not plant near squashes or melons as they aro likely to mix. About three pounds of seed will plant one acre.

CALIFORNIA FIELD-The well-known ordinary Pumpkin, largely used for stock-feeding. The fruit is variously colored in yellow, drab, red and orange, and varies also in size. but is usually very large. Is a heavy crop. per and easily grown. Pkt., 10e; lb., 60c.

CONNECTICUT FIELD-This is widely known as the Yankee Cow Pumpkin, and there is no variety that will do as well among the corn. Plant them on your richesi land; you will be amply repaid. Pkt., 10e; oz., 15e; 1/4 1i).. 30c; 1b., \$1.00.

CUSHAW or CROOKNECK - Very productive, color light cream, sometimes lightly striped: flesh vellow, mealy, sweet. Pkt., 10e; oz., 15e; $1 / 4$ 1b., 30e; lb., \$1.00.

SMALL SUGAR or NEW ENGLAND PIE-This excetlent varietv is small, round or somewhat flattened, abour 8 to 10 inches in diameter, slightly ribbed, and of a deep orange color. The flesh is a rich deep yellow, finegrained and very sweet. A superb kind for pies. Pkt.. 10e; oz., 20c; 1/4 ib., 40c; 1 b., \$1.25.

MAMMOTH IKIN-Flesh and skin bright golden yellow. Flesh fine grained, excellent quality. One of the best pie pumpkins and a splendid keeper. This ellormous variety has been grown to weigh 200 pounds. Fkt.,

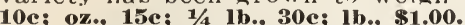

LARGE SWEET CHEESE Or IE NTUCKY FIELD -One of the old standard sorts. Flat and often 20

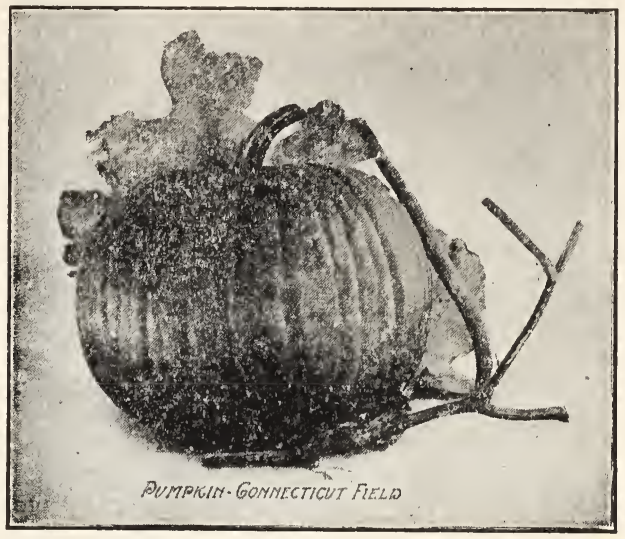

inches in diameter; skin buff; flesh thick, yellow and of fine quality. Productive and an excellent keeper Good for stock feeding as well as pies. Pkt., 10e; oz., 15e; $1 / 4$ lb., 30e; $1 \mathrm{b.s} \$ 1.00$.

\section{Knox's Oregon Grown Potatoes}

600 pounds will plant un acre.

We are large handlers of all varieties of Potatoes for Seed. Write for Prices when interested.

It is best to cut the Potatoes with two or three eves to a piece, planting these in row's or hills about 3 feet apart and ahout 15 to 18 inches apart in the row. Write for prices, as market fluctuates.

AMERICAN WONDER-This early white potato is becoming more popular each year; it is a good size, smooth, and a splendid keeper. As a producer it has no equal among early potatoes. We have excellent strains for both Oregon and California seed of this variety.

BURBANKS-A standard late variety. It is of good size, of fine form and an excellent yielder. The flesh is white, very niealy and of fine flavor and quality. This variety is well adapted to heavy soils.

WISCONSIN PRIDE-A medium early heavy cropper potato. The most favored of the market gardener.

EARLY ROSE-This pink-skinned variety is noted for earliness, productiveness and fine quality.

BRITISH QUEEN-A white pitato about the same shape as the White Rose. It is noted for its very heavy yield.

WHITE IROSE-A variety with the earliness of a Red Rose and all the qualities of a good white potato. A very good producer. Somewhat longer than the Red Rose.

PEERLESS-A medium early white potato. A very heavy producer. Tubers are somewhat round of very good texture and flavor. Very popular.

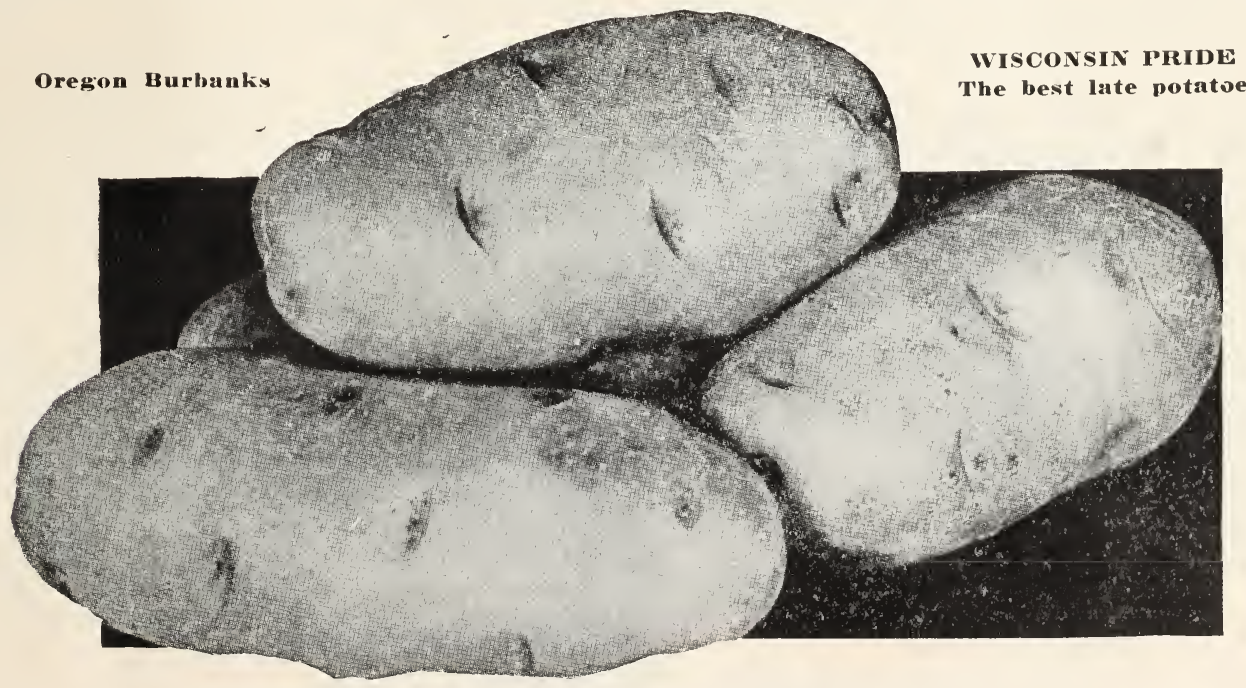




\section{Knox's Radishes}

One ounce will sow 100 feet of drill, 8 to 12 lbs. per acre. For first crop as early in the spring as the ground can be worked, and every two weeks throughout the season for succession. A warm, sandy loam. made rich and light by strong manure, is best. Sow in drills 10 to 12 inches apart. The winter varieties should be sown in July and August.

EARLY SCAIRLET TURNIP-A rich scarletred radish, turnip-shaped with small top. Flesh is white, crisp, tender and of mild
flavor. This Radish is of very rapid growth and a standard variety. Pkt., 10c; oz.. 15e; 1/4 Ib., 35c; 1b., 75c.

LONG WHITE ICICLE-For the home garden we consider this a most excellent table variety. Its extreme earliness, beautiful, pure white appearance, excellent flavor and crispness should make it a favorite everywhere. Pkt., 10c; oz., 15c; 1/4 Ib., 35e; lb. 75e.

LONG SCARLET-Fiery scarlet, the brightest color of any Radish, tipped with white: early, maturing in 0 , tipped with white: early, maturing in 20 to 25 days: crisp and
tender. Pkt., 10c; oz., 15c; 1/4 1b., 35e; lb. 75e.

IROUND HLACK SPANISH-A general favorite. Very similar to Long Black Spanish except in shape, which is round to top shaped. Skin black, flesh white and pungent; keeps well. Pkt., 10c; oz., 15c; 1/4 1b., 35c; 1b., 75c.

WHITE-TIPPED EARLY SCARLET TUR NIP RADISH-For many years we have found this variety to be the most popular of all among private gardeners, and unsurpassed as a table Radish, where by reason of the strong contrasting colors of the root it makes a most attractive flesh is crisp, white and tender, and extremely mild.

CHINESE ROSE-Very popular with market gardeners: very smooth. bright rose color large. Pkt., 10c; oz., 20c; 1/4 lb., 35e; lb., 75c.

CALIFORNIA WHITE MAMMOTH - Long white, of large size. A good keeper; flesh tender and crisp. Pkt., 10e; oz., 15c; $1 / 4$ lb. 35c; Ib., 75c.

CRIMSON GIAN'T-A large sized extra early turnip radish a little longer in shape than the Scarlet Turnip but brighter red color twice the size. It grows quickly and even when it attains large size remains tender and of fine flavor to the last. Will prove a money-maker for the market gardener, as its bright crimson color makes it a seller on first sight. Equally valuable for home garden use. Pkt., 10c; oz., 15c; 1/4 lb., 35c; 1b.. 75c.

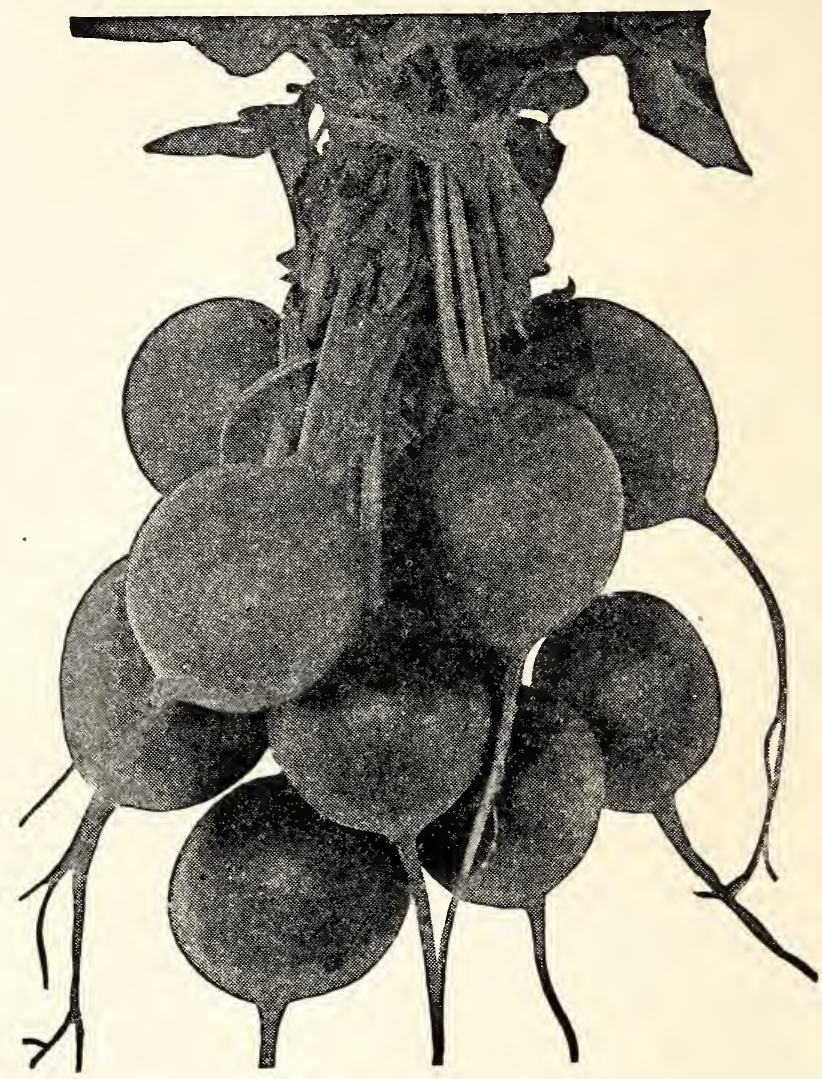

Spinach

This plant will grow in any ordinary soil, but responds well to fertility. Sow early in the spring in drills twelve to eighteen inches apart. For early use sow light covering of leaves or straw. One ounce of seed will sow fifty feet of drill.

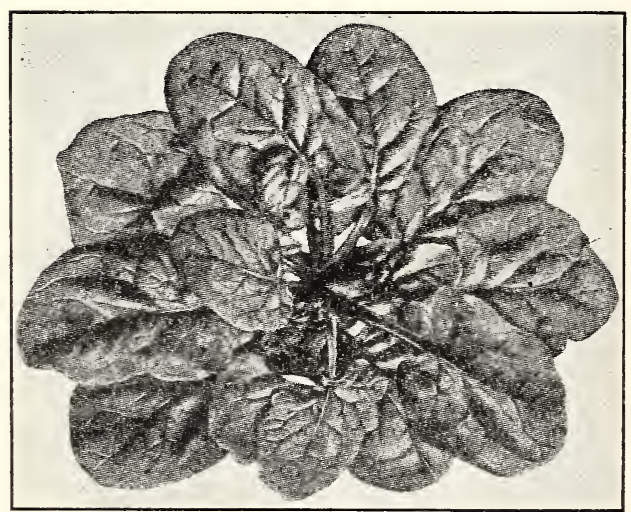

Amsterdam Giant
This plant will grow in any ordinary soil, but responds well to fertility. Sow early in the spring in drills twelve to eighteen inches apart. For early use sow in August or September, protecting the plants with a light covering of leaves or straw. One ounce of seed will sow fifty feet of drill.

PRICKLY or WINTER-Especially recommended for fall sowing, although it does well if sown in the spring. The plants grow quite large and the light green leaves are medium sized, thick and fleshy. It goes to seed sooner than some other sorts.. Pkt., 10c; 1/4 1b., 20c; 1b. (60e.

SAVOY LEAVED or BLOOMSDALE - Leaves are very curled and crumpled. It is early and very hardy, being splendid for winter use. Much used by Southern truckers as it is a splendid shipper. Pkt., 10c: 1/4 1b., 20; it.., (60c.

LONG STANDING-An improved strain of excellent merit having all the good qualities of the ordinary sorts, and especially desirable hecause it is much later in going to seed. Pkt., 10c; 1/4 1b., 20c; 1b., 60c.

GIANT AMSTERDAM-This variety has become popular as an all-around Spinach. It is desired by the grower because it is hardier than other varieties and will produce in tonnage per acre more than any of them. The canner and shipper like it because of its large smooth leaves. The consumer prefers it because it is exceedingly tender and of mild flavor. Pkt., 10c; 1/4 1b., 25e; lb. 60c. postpaid. 


\section{Knox's Squash}

Any good enriched soil is adapted to the growing of the Squash. The seed should not be sown in the spring until danger from frost is past and the ground is warm. Plant in hills (about 8 to 10 seeds to a hill) the early sorts 4 to 6 feet apart, the late varieties 8 to 12 feet. Thin out to three plants in the hill. Keep the earth about the plants loose and free from weeds. One ounce for 25 hills, 3 to 4 pounds per acre.

EARLY WHITE BUSH-This is the well known White Pattaypan Squash. The earliest to mature, very productive, light cream colored. Pkt., 10c; oz., 15c; 1/4 1b., 35e; lb., \$1.00.

GOLDEN SUMMER CROOK NECK-Early and prolific. The fruits are of the true crook-neck type, heavily warted, and of light golden color: about one foot long. Pkt., 10e; oz., 15e; $1 / 4$ lb., 35e; lb., \$1.00.

BOSTON-MARROW-A very prolific fall and winter Squash of medium to large size and oval shape. The thin skin is orange-yellow in color; flesh is rich salmonvellow, fine-graired and of excellent flavor and quality. Pkt., 10e; oz., 15e; 1/4 1b., 35e; \$1.00.

PERFECT GEM or CREAM-Long-keeping winter Squash, 4 to 6 inches in diameter; apple-shaped, distinctly ribhed with smooth, cream-colored skin. Is solid and rather hard, but bakes to a delicious soft consistency on the inside. Although a small variety, it is a great keeper and is used mostly in winter. Pkt., 10c; oz., 15e; 1/4 1b., 35e; 1 b., \$1.00.

BANANA-This squash grows from one to two feet in length. Flesh firm and solid, of beautiful orange-yellow and excellent quality. It keeps from one season until another. When quite young it is excellent to cook as a morrow. Pkt., 10c; oz., 20c 1/4 lb., 50e; 1b., \$1.50.

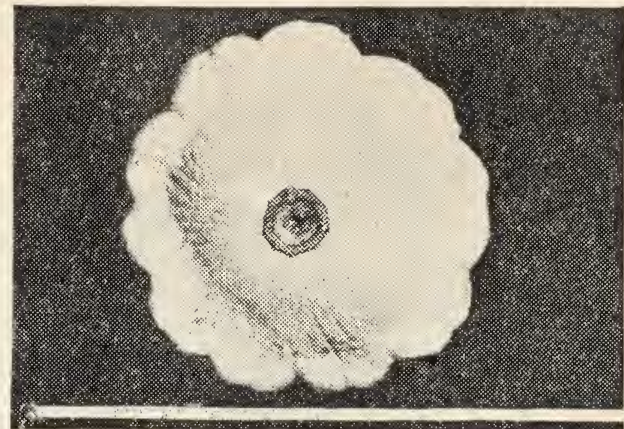

White Bush Seallop

GOLDEN HUBBARD-The flesh is of a deep golden yellow-a much richer color than the excellent flavor In its keeping qualities it is fully equal to the green variety. Pkt., 10c; oz., 15e; 1/ lb., 35e; 1 b.. $\$ \mathbf{\$ 1 . 0 0}$.

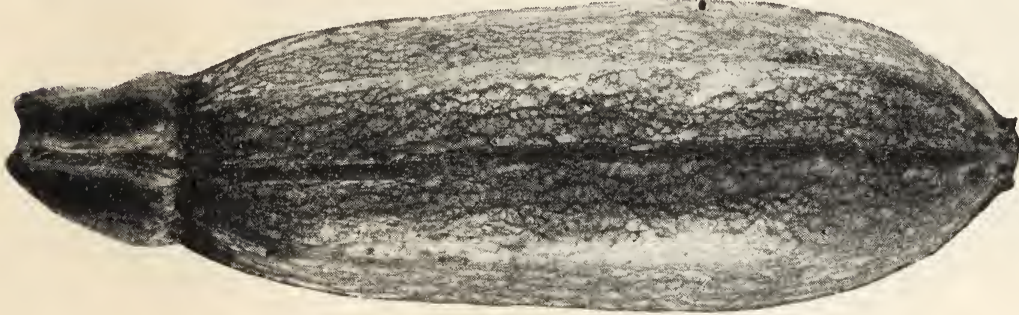

Zucehini

COCOELLE SQUASH-Is a bush variety, and should be planted 5 feet apart. It should be used when quite young. When served it has a rich creamy flavor not equalled by any other squash. Soine gardeners have made considerable money naking a specialty of it. For the family garden we would recommend its use instead of the small White Bush Scallop, because of its excellent flavor. Since our introduction of this squash a few years ago, it has now become one of the staple products on the market. It is listed with the daily market reports, and is grown largely by the gardeners in frostless sections for the early trade. Pkt., I0c., or., 15c: $1 / 4$ 1b., 45c; $1 \mathrm{b.} . \$ 31.50$.
ZUCCHINI SQUASH - The favorite Italian squash. Grows from five to eight inches in length, is one of the most prolific early Summer varieties and is popular on the market and for home use. A few hills of Zucchini will suffice to keep the family well supplied for the entire Summer. Market gardeners will find our seed highly satisfactory for producing uniform and marketable size squash. Pkt., 10e; 0z., 15e; 1/4 lb., 45e; lb., \$1.50. Prepaid.

GREEN WARTED HUBBARD-This variety is grown more largely throughout the United States than any other It is used in many ways, but mostly for pies. It is a good keeper and because of its hard warty rind, it is the best of shippers. Therefore many acres are grown in Southern California for that purpose, and many more for the bakers. the canners and family consumption. Pkt. 10e; oz., 15e; $1 / 4$ lb., 35e; lb., \$1.00.

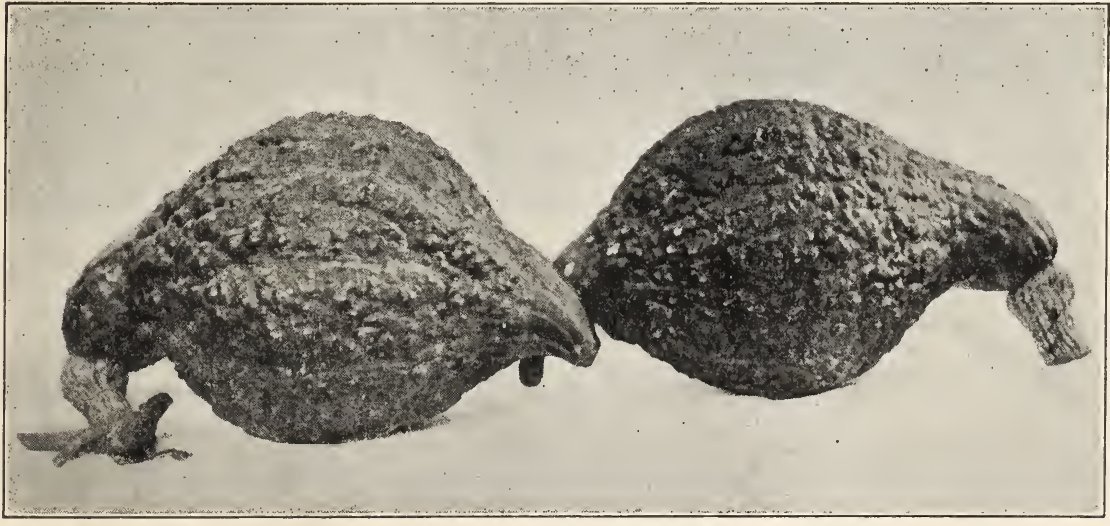

Green Warted Hubbard
VEGETA BLE MARROW-The fruits are oblong in shape, skin smooth and creamy white. The plant is vigorous and very productive. Marrow Squashes are largely grown in England and should be more generally used in this country. as the quality is exceedingly delicious. Whe $\mathrm{n} t \mathrm{~h} e$ fruits are nearly half grown the flesh is very tender and marrowy, and may be prepared for the table either cooked or fried. Pkt., 10e; ox., 15e; 1/4 lb., 35e lb., \$1.00, prepaid. 


\section{Knox's Tomatoes}

Tomatoes succeed best in well manured, light sandy soil. For early plants sow seed in boxes or hotbeds in January. When the plants are about two inclies high transplant to four inches apart each way. Set out of doors as soon as danger of frost is over. Transplait carefully, six feet apart each way, and cultivate well as long as vines will permit. To obtain early fruit pinch off the ends of the branches when the first fruit is set. Our seed stock is of the very best selection. One ounce of seed for 2,000 plants.
Tomatoes
are a sure
crop

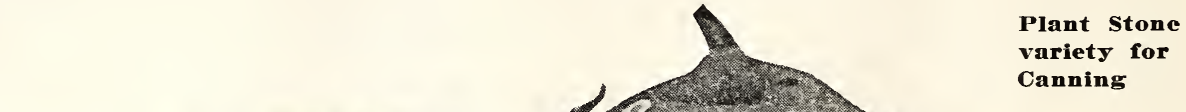

Do not plant

too close

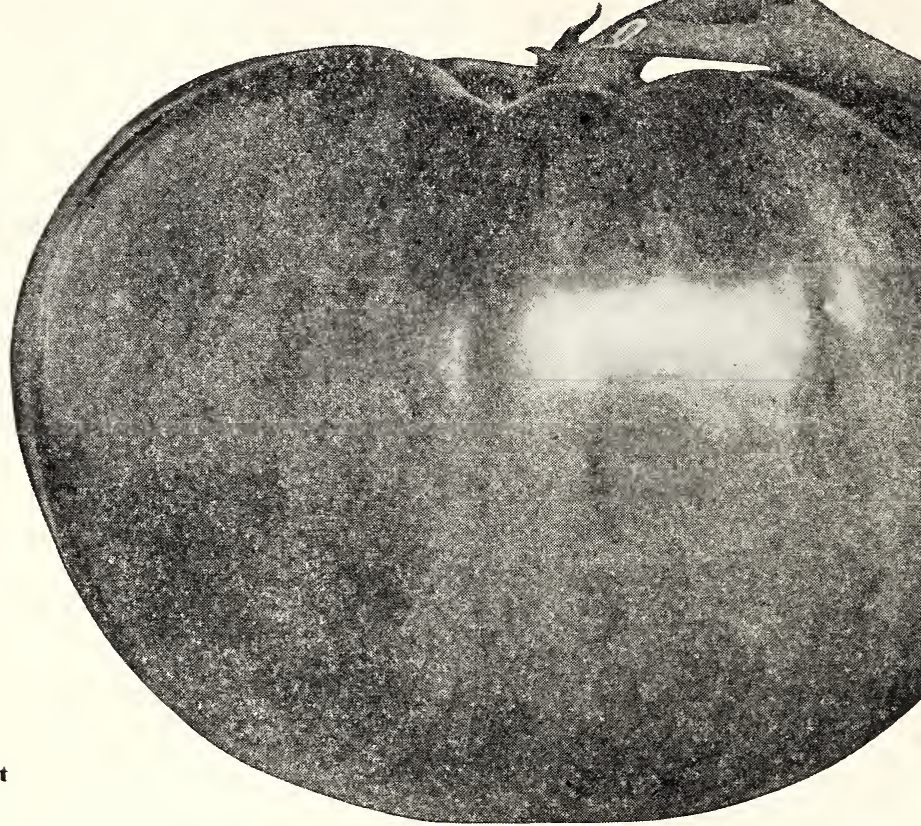

Ponderosa
Do not water when in bloom
PonderosA-The largest tomato in existence The vines are vigorous and tall growing and extremely prcductive. The purplish-pink fruits are very solid with few seeds, fairly smooth, and con sidered of very good quality by those who prefer a tomato auite free from acid. Ripens about midseason. Desirable for slicing. Pkt., 10c; oz., 50c; 1/4 Ib., \$1.50; Ib., \$4.50.

NEW STONE-It ripens for main crop, is very large and of bright scarlet color, very smooth. ripening evenly to the stem witlout a crack: exceedingly solid and firm fleshed. Pkt., 10c; oz., 50c; 1/4 Ib., \$1.40; 1b., \$4.50.

NEW MARGLOBE TOMATO-The Popular Wilt and Nailhead IRust-Resistant Sort. 100 days. (Bright Red). This grand new tomato was developed by the U. S. Department of Agriculture and thoroughly tested in sections where Wilt and Rust diseases are very destructive. If you have met with disappointment in growing tomatoes on account of Wilt or Rust, you will be interested in this new tomato. Marglobe produces a very heavy crop either on infested soils or on soils from diseases, producing large smooth, deep globe-shape, meaty, bright red tomatoes, in 100 days. Ripens uniformly even around the stem and resists cracking well. A heavy yielder. Excellent sort for the home garden, market gardeners, canners or greenhouse culture. Pkt., 15e; oz., 50c; $1 / 4$ lb., $\$ 1.50$; 1 b., \$5.00.

CHALK'S EARLY JEWEL-About ten days later than Earliana, a good yielder, colored scarlet smooth, with much better core than Earliana. Our strain of this tomato is of the very best. Pkt. 10c; oz., 45c; 1/4 Ib., \$1.25; Ib., \$4.00.

SPARK'S EARLIANA-A perfect early tomato large in size and beautiful in color, nearly seedless and very solid, a vigorous grower and prodigious bearer. yielding its snlendid fruit until frost. Pkt., 10c; oz.. 50c; $1 / 4$ lb., \$1.50; lb., \$5.00.
SAN JOSE CANNER-This is a large fruited variety, rather late in ripening, producing a large fruit. Has a small core, is very meaty and large fruit. Has a small core, is very meaty and to frost time. Highly recommended for canners. Pkt., 10c; oz., 35c; 1b. $\mathbf{8 3 . 5 0}$.

TOMATO NORTON OR WILT RESISTENT STONE -Introduced by the United States Department of Agriculture. It is the result of work accomplished by Dr. Prichard to produce a variety resistant to Fusarium Wilt, a disease prevalent in different parts of the United States. Besides being resistant it is a good variety in disease free soil, resembling closely the Improved Stone. Perhaps a litile later than Stone, it is very prolific. The fruit is smooth and bright red in color. It requires a full season to mature. Pkt. 10c; 1/2 oz., 25e; oz., 40c; $1 / 4$ Ib., \$1.50; Ib., \$6.00.

GROUND CHERRY-Husk or Strawberry Tomato. Fruit golden yellow, size of a cherry. The preserves, sauces or pies; very productive. Pkt., 10c; oz., 30c; 1/4 lb., \$1.00; Ib., \$3.50.

\section{TOMATO WORM}

The moths appear in May or June and deposit the eggs singly upon the lower surface of the leaves from which the caterpillars hatch in 4 to 8 days. As they feed voraciously they become full grown in $\mathbf{3}$ weeks time. There are sometimes two broods in a season. The most successful remedy is Arsenate of Lead. 


\section{Knox's Turnips}

Turnips are cool weather plants and thrive best in spring and fall. For early use seed should be sown as soon as the ground can be prepared and will give roots large enough for the table in six to ten weeks. For the fall crop seed should be sown June to August and the plants will grow until freezing weather, when they should be harvested and stored. Rutabagas after a touch of frost are a delightful addition to the winter diet. To avoid maggots, it is best to sow turnips on different soil each year.

A loose and fertile soil is needed to mature early turnips rapidly, and avoid a bitterness which develops when growth is checked. The plants should be thinned to stand three inches apart, and then the half grown roots should be harvested alternately.

For the Home Garden-any of the table turilips and rutabagas listed on this page will be found satisfactory.

YELLOW GLOBE GREEN TOP-A yellow-fleshed globe-shaped variety of medium to large size, smooth and of light yellow color with small green crown. Flesh is light yellow. Pkt., 10c; oz., 15e; $1 / 4$ 1b., 35e; $1 \mathrm{~b} ., 75 \mathrm{c}$.

PURPLE-TOP, STRAP-LEAVED-A very early strap-leaved variety having scant erect, entire, stift leaves. Roots are regular in shape, flat and medium-sized, purple-red above ground, white below. Flesh is white, fine grained, and tender. Best when $21 / 2$ inches in diameter. Pkt., 10c; oz., 15e; 1/4 1b., 35e; 1b., 75e.

WHHTE EGG-Popular early Turnip, adapted for either spring or fall sowing. The solid roots are egg-shaped, perfectly smooth and pure white. The sweet, firm flesh is always mild, rich and fine flavored. Attains good size, yields well and keeps a long time in best condition, is planted much for home use. market and time in best condition, is planted much for home use. m
for stock raising. Pkt., 10e; oz., 15e; 1/4 lb., 35e; 1b., 75e.

PURPLE TOP WHITE GLOBE-As indicated by its name, this variety is white under ground, purple above, flesh white, fine grained and tender; should be used when about three inches in diameter. Keeps well and good for market use. Pkt., 10c; oz., 15e; 1/4 1b., 35e; 1b., 75e.

EARLY WHITE FLAT, DUTCH-A most excellent early variety. Roots medium size, flat, color white: very early; sweet and tender. Pkt., 10e; oz., 15e; 1/4 1b., 35e; lb., 75e.

WHITE EGG-Is nearly oval or egg-shape, as its name would Indicate; flesh very firm and fine-grained; thin and perfectly smooth skin, and both flesh and skin are snowy white. Pkt. 10e; oz., 15e; 1/4 1b., 35e; lb., 75e.

COWV HORN OR LONG WHITE-This varlety is a great field turnip and is carrot-like in form, growing nearly half out of the ground. Fine quality, good keeper. The flesh is fine grained and well flavored. Desirable for stock breeding. Cowhorn is planted extensively for feed and for green manuring. Pkt., 10e; oz., 15e; 1/4 1b., 35e; 1b., 75e.

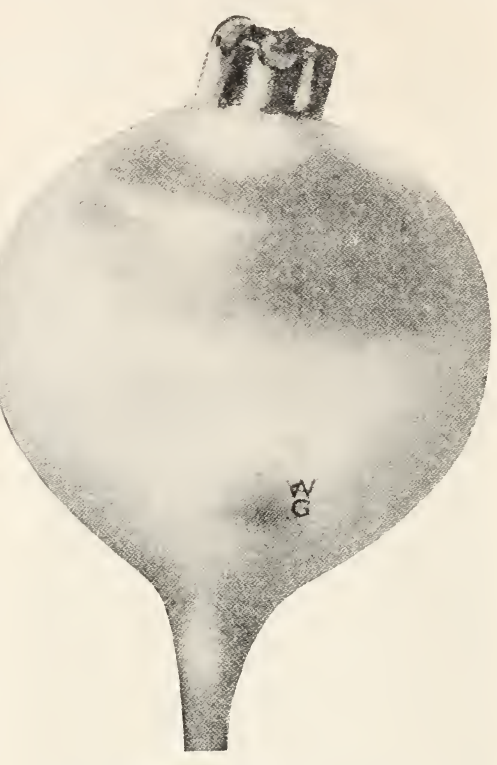

Purple Top White Globe

\section{RUTABAGAS OR SWEDES}

Requires a longer season than turnips. For table use they keep better, and better flavored than the turnip. For stock in fall and winter there is nothing superior to turnips and rutabagas, as they are liked by all kinds of stock and keep them in good condition.

IMPROVIOD AMEIRICAN PURPLE TOP-Our strain is remarkable for uniform shape and fine quality, and is splendid keeper. The roots grow to a large size, have small tops. short necks and smooth skin: flesh is of a beautiful vellow color, fine grained, very sweet, tender and of excellent flavor. Pkt. 10e; oz., 15e; $1 / 4$ 1b., 35e; lb., 75e.

THE NEVER-FAIL GOPHER GUN AND BURGLAR ALARM

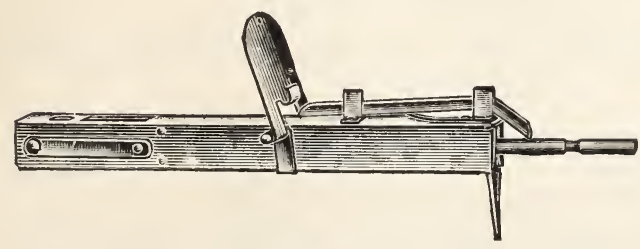

Patented Oet. 17th, 1922

May be used as a gopher gun by placing in gopher hole. Gopher sets off the gun by touching tricer if us be tached to thread so that anyone walking across tached to thread so that anyone walking across
floor will set off the gun. Uses .38 blank cartridges, which may be bought at any hardware or general store. Cartridges cannot be sent by mail. Directions for use accompany each gun. Price \$1.75 each. By mail, \$1.85.

\section{NOTICE}

We maintain a complete spray department and we are always at your service to help you solve your spraying troubles. Should insects appear in your garden or orchard and you do not know what to spray them with, write us, giving complete description, and we will endeavor to help you eradicate them. We have on hand quantities of spraying literature which we will be glad to mail you free of charge. 


\title{
Knox's Selected Field Corn
}

\author{
EARLY MATURING-HEAVY YIELDING
}

Proper selection of Seed Corn is a matter of working year after year, planting good seed in the beginning, watching the particular stalkss which grow best and which set enough ears the proper distances from the ground, and then cutting the tassels from all other stalks in the field. The seed ears must be selected on the stalk, and ripened and dried under correct conditions. The grains must be shelled and stored and graded so they will be even in size, and their vitality maintained unimeaired. Finally, the seed must be tested for germination. We have picked growers who give their Corn crops the attention necessary to produce first-class seed.

\section{DELTA DENT (Yellow)}

\section{CALIFOR N IA GROWN FOR CALIFORNIA CONDITIONS}

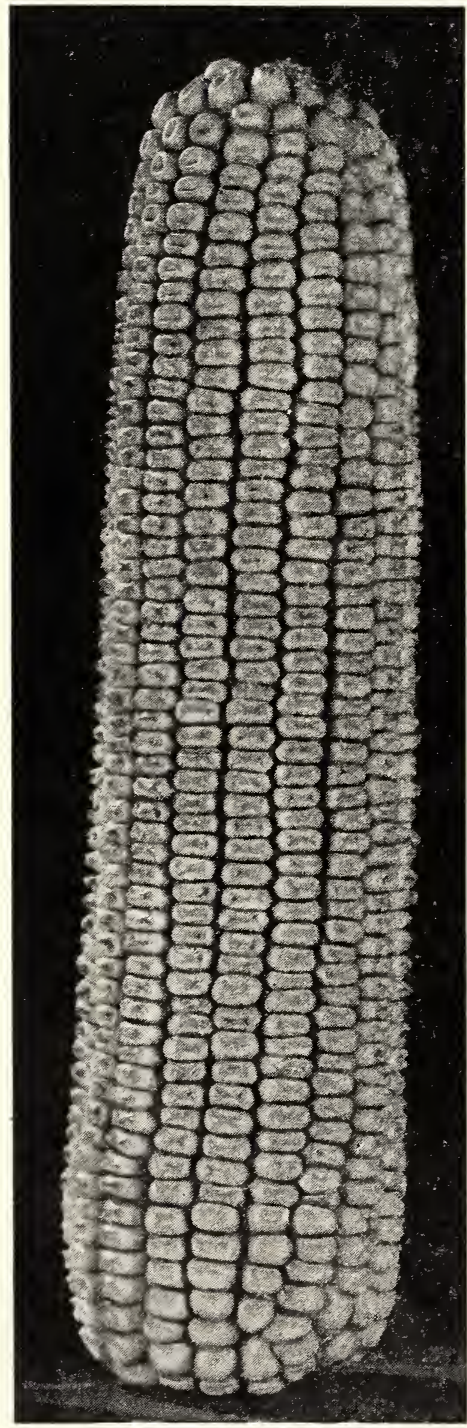

Callfornia Delta Dent
KNOX'S DELTA CORN is an extra early yellow dent corn, maturing in 85 to 90 days from planting. It shows a thoroughbred type of ear, well formed and covered from tip to end with large, deep kernels of rich golden-yellow color. The ears are of medium size, with exceedingly small cob, yielding more pounds of shelled corn per bushel of ears than many of the larger and later varieties. It is a very heavy yielding corn, nearly all stalks producing two well developed ears, and no barren stalks. Ears average from 7 to 9 inches.

KNOX'S DELTA DENT is of strong growth, deep rooted and stocky, withstanding drought to a remarkable degree. The stalks grow 8 to 12 feet tall and are very leafy. Another valuable characteristic is its wonderful adaptability to different soils, producing heavy yields on light as well as heavy soils.

KNOX'S DELTA DENT is the earliest maturing, full yellow dent corn suitable to the soil and climate of California and has by far the widest range of usefulness.

Our seed of DELTA DENT has been grown in Central California for a number of years, and is therefore adapted to all the delta country of California. We cannot recommend this variety too strong.

Price, 1 lb., 10c; 5 lbs., 40c; 10 lbs., 75c; 50 lbs., \$3.50. Not Prepaid

\section{KING PHILIP, THE STANDBY FOR YEARS}

Our remarkable strain of King Philip is gaining in popularity every year. Through careful selection and handling we have kept our strain far above anything else offered. When you buy Knox's King Phillip you are sure you are getting the best that can be obtained.

Price 1 lb., 10c; 5 lbs., 40c; 10 lbs., 75c; 50 lbs., \$3.50: $100 \mathrm{lbs}, \$ 6.00$; not prepaid 


\section{Field Corn--Continued \\ Write for quantity price}

\section{EARLY LEAMING}

One of the best all around heavy yielding Dent Corns of today. Known everywhere as a heavy yielding yellow Corn. Produced 1,238 bushels on 10 acres. Ears about 10 inches long; 18 to 20 rows, well filled with wedge shaped, redishyellow kernels of medium size. We have increased the size of the ear, its earliness and also the percentage of grain by careful breeding. Ripens in about 95 to 100 days. Ear, selected hand picked. Lb., 10e; 10 lbs., 85e; 100 lbs. ask for price.

\section{HICKORY KING}

Has the largest grains, with smallest cob. of any white corn introduced. We have what is known as the Broad Grain Hickory King; a single grain nearly covering a cross-section of the entire cob. It is a strong grower; the stalks take a firm hold on the ground and stand upright, resisting heavy wind storms without blowing down. In fairly good soil each stalk bears 2 and sometimes 3 medlum sized ears. It yields good crops on light soils and is one of the most productive and profitable white varieties for planting in the South. Ears fill out well and will make more shelled corn to bulk of ears than any other variety. It is good for roasting ears to follow Early White Dent; makes a splendid quality of corn meal, and is just the right sort for stock feeding, being almost all corn and very little cob. It matures fully in from 115 to 125 days. Lb., 10e; 10 lbs. 85e; 100 lbs., ask for price.

\section{REID'S YELLOW DENT}

We recommend it very highly for California but not for Oregon or Washington, except for fodder or silo. Very popular because of large ears, which are uniformly smooth and light yellow in color. An ideal show variety, and easy to sell because of its high breeding, uniformlty and large percentage of grain to cob. Shells 88 per cent grain and often better. Ears run 8 to 11 inches long in different localities, and 7 to 8 inches in circumference. An immense yielder on good soil. Some Northern farmers grow Reid's for the silo because of its large growth. The small shank makes it very easy to gather and husk. Matures in 105 to 110 days. Our seed stock this year is Ohio grown, is extra early, and is adapted to California climate. Lb., 10c; 10 lbs., 85e; 100 lbs., ask for price.

\section{EUREKA ENSILAGE}

Eiureka Ensilage corn is without a doubt the heaviest yielding ensilage corn adapted to California climatic conditions. It grows to an average height of 14 feet, has very leafy stocks bearing one to three ears to the stock, and has established a record of an average production of 30 to 35 tons per acre. This when cut and put in the silo furnishes a feed that is very succulent and of the highest feeding value and is relished by all kinds of stock.

Our seed stock of Eureka Ensilage Corn for this season is of exceptionally fine quality and selected for size uniformity for both ear and kernel.

Price per lb, 10e; 10 lbs., 85e. Write for quantity prices.

\section{OTHER VARIETIES}

IOWA GOLDMINE---This corn ripened thoroughly inside of 100 days. It is one of the most generally planted varieties. The ears are about 10 inclies long and very synmetrical. The grain is very deep and of beautiful golden yellow color, and the cob is very thin. Iowa Goldmine is a heavy cropper, and one of the most productive early varieties. Our 10 lbs., 85e; 100 lbs., ask for price.

IOWA SIIVISR MINE-Standard white dent varieties; superior for feeding purposes and also makes good roasting ears when young. Lb., 10e; 10 1bs.s 85e.

A USTRALIAN WHUTE FIINT-A 90 -day variety an ideal for our arid lands. Will endure more drought and cold than any other variety. Ears about 12 inches long. Lb., 10e; 10 lbs, 85c.

\section{POP CORN}

WHITE RICE-Handsome variety; kernels long, pointed and resembling rice; color white. Very prolific. Lb., 15e.

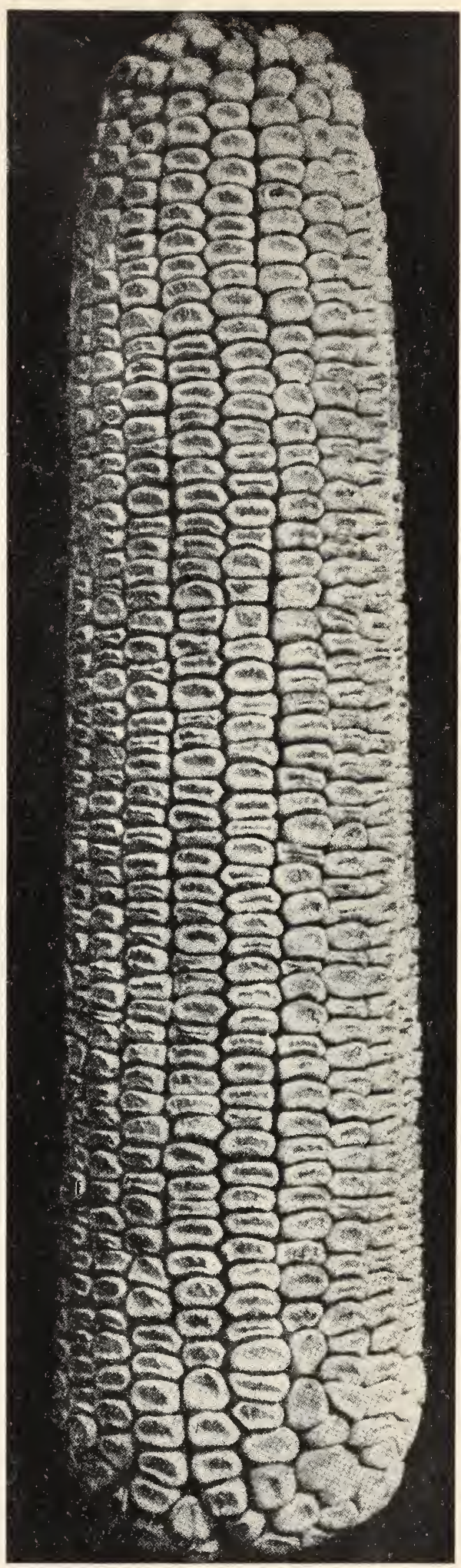

Reid's Yellow Dent 


\section{KNOX'S FARM SEEDS}

We claim that we sell the highest grades of Grass and Clover seeds that are offered in this country. We do not intend to compete with samples offered by commission merchants, many of whom have no knowledge of the seeds they sel, whether good bad or entire cost of the seed. The prove poor or mixed, the loss to the planter is ten times more than the entis from 1 to 2 cents per difference in the price between choice, clean seed and scond or third quality is from to to che cents per pound. Every intelligent farmer knows that the best seed that can be obtained is the cheapest in ject to change. Be sure to obtain our samples and prices before you buy elsewhere. Special rates on large quantities.

AMERICAN or LIBERTY MILLETT-Will grow on any good land and yields heavily when artificially watered; yields from 40 to 30 bushels of seed to the acre, which is excellent food for stock or poultry. A good on large quantities. Lb. 10c.

ORCHARD GRASS-This grass is extremely quick to recover Irom close cropping and is highly valuable on account of its earliness and rapidity of growth. Succeeds on almost any soil, especially in meist, shady places. It exhausts the soil less than other grasses and withstands drought. keeping green when other grasses are burned up. It is inclined to grow in tufts and should therefore be sown very eveniy. Sow 40 to 50 lhs. to the acre. Lb., 35e:

TIMOTHY - This perennial grass thrives best in moist, loamy soils, attaining a height of 4 feet, and is exceedingly nutritious, making fine hay Sow 35 to $40 \mathrm{lbs}$. to the acre. Lb., $25 \mathrm{c}$.

FETERITA-Resembles Kaffir Corn but is more productive. It stands drought well and is, therefore, valuable in arid tracts. Five pounds $w$ ill sow an acre. Lb., 15e.

RAPE, DWARF ESSEX-A splendid pasture plant for all kinds of live stock and especially valuable for fattening sheep. It can be sown at any time during the spring or summer and will be ready for pasturing within six weeks from time of sowing. Sow broadcast, 8 lbs. to the acre. Lb., 20c.

SORGHUM Or EARLY AMBER CANE-If not allowed to grow too high, can be cut several times through the season and makes good sweet hay. Sow broadcast, unless the soil is quite sandy, when it is best to sow in drill. Lb., 15e.

KAFFIR CORN-An excellent fodder plant, yielding two crops of fodder during a season. It grows from four to five feet high, making a straight upright growth. For the grain, sow in rows 3 feet apart, 6 to $10 \mathrm{lbs}$. of seed per acre. For fodder. sow 1 to $1 \frac{1 / 2}{2}$ bushels either broadcast or in drills. Lb., 15c.

PEAS, CANADIAN FIELD-These are usually sown with oats and cut for a green cover crop. Lb., 15e.

COWPEAS, WHIPPOORWILL-Especially good in the North and West as it matures early. Lb.. 15e.

SUNFLOWER, MAMMOTH RUSSIAN-An excellent and cheap poultry food. Three pounds of seed will plant an acre. Lb., 15c.

SOY BEAN-An excellent green fodder and silage plant, as well as a valuable forage crop for green manure. Sow after danger of frost is past. sow in drills 4 feet apart, using 4 pounds of seed to the acre. Lb.. 15e.

COWPEAS, BLACK EYE-One of the best varieties that can be secured when the oats head, but before the grain is ripe. For best results sow 40 lbs. of oats and $100 \mathrm{lbs}$. of peas to the acre. Lb., 15c.

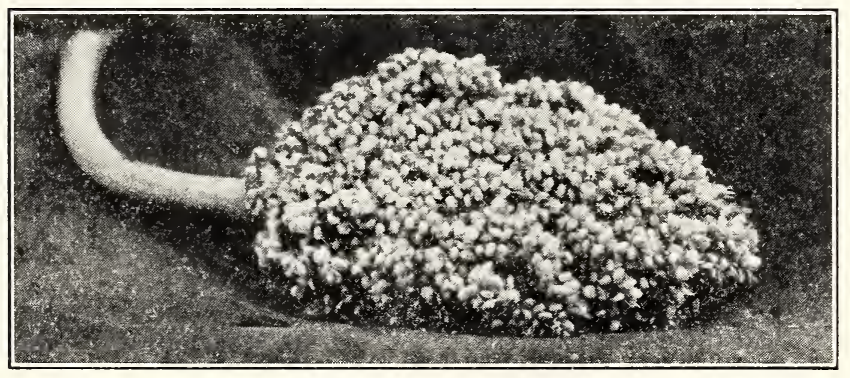

A Fine Head of Knox's Egyptian Corn
E G Y P TIAN CORN -A good $\mathrm{s} \mathrm{tr}$ a in for dry sections and seasons. The grain is s m a ll and can be used a s chicken f e e d. Lb. 10c.

B R O O M C O R ND W A R FThis is the used for the manufacture of brooms. Grows very productive. Six to $8 \mathrm{lbs}$, to the acre. Lb., 15e.

HENP, KENTUCKY - A staple crop, sown broadcast using $25 \mathrm{lbs}$. of seed to the acre. For a seed crop. should be sown in hills 4 feet apart. Grows 12 to 14 feet high. with deep-cut, dark green, fragrant leaves. Lb., 15e.

COW KALE - This will yield a much heavier crop than Dwarf Essex Rape and is now considered superior to Rape in some sections. It grows to a height of 3 to 4 feet. Hogs and sheep eat it greedily. It grows well and produces heavily on most any land and the plant is quite hardy. The seed can be sown early in April or any time thereafter till midsummer. Pkt., 10c; $1 / 4$ lb., 25c; Ib., 75e.

MILO MAIZE-Very similar in manner of growth to Kaffir Corn, but is preferred by many growers who claim that it produces more grain per acre and better quality of forage than any of the non-saccharine sorghums. It is grown and handled in same manner as Amber Cane or Kaffir for hay and fodder and will make splendid ensilage if cut up with corn. Lb., 15e.

SUDAN GRASS-Sudan is a tall, a nnual grass, reaching a height of from seven to nine feet when planted in rows and allowed to mature for a seed crop; broadcasted and cut "in the bloom" for hay. about four feet.

The hay is softer than Johnson Grass or Surghum, the stems are smaller and more leafy.

It is easily cured and handled as a hay crop. Stock of all kinds eat it readily and will leave any other hay for $1 \mathrm{t}$.

For seed crop plant $2 \mathrm{lbs}$. seed per acre in rows 36 inches apart. For hay crop broadcast or drill 12 to 20 lbs. to acre. Yields 500 to 1,000 lbs. seed or three tons cured hay per cutting ner acre with three cuttings per season. 


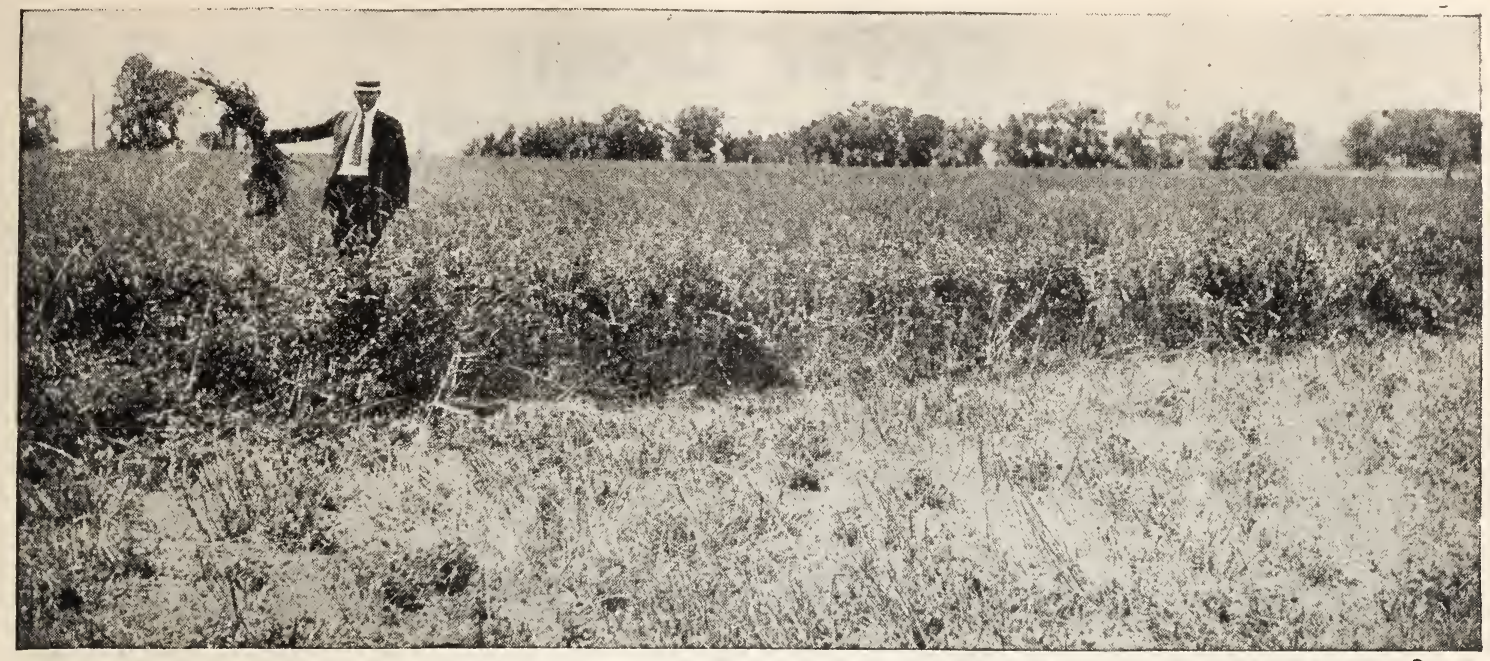

\section{ALFALFA OR LUCERNE CLOVER}

Alfalfa or Lucerne Clover is the most talked of and most widely planted of all the varieties of clover in the world. It is said that the feeding value of a ton of Alfalfa is equal to a ton of shelled corm. Alfalfa will produce 5 to 7 tons of hay to the acre each year and in true value is worth $45 \%$ more than other clovers. It will grow 4 to 5 crops a year and it does not exhaust the soil; it enriches the soil. Its long branching roots penetrate far down, 15 to 20 feet, and so loosen the subsoil that it is a gigantic subsoiler, resists drought, and gets plant food where other crops would be a failure. When the plants are destroyed in order to raise other crops on Alfalfa land, the large roots decay and produce a vast source of fertility to be used by following crops.

Although fall sowing is preferable, fine results can be obtained from early spring sowing. Give it care and attention. especially the first year, and your trial will show you that you cannot afford to be without it.

Do not buy cheap Alfalfa seed. If it's cheap, it is not pure Alfalfa but mixed with weed seeds Weeds are very troublesome to Alfalfa, crowding it out and ruining the quality of your hay, so be sure to get the highest grade seed and no other kind. This is absolutely essential to success. Sow in thoroughly prepared soil. either broadcast or in drills, at the rate of 20 pounds per acre.

HAIRY PERUVIAN-We first offered this variety in 1918. It is hardier and it does produce more hay the first year than common alfalfa, but it does not endure as well. Many large growers now prefer the common alfalfa. With these comments we offer the Hairy Peruvian Alfalfa to those who may have had better results and yet prefer it. Write for quantity price. Ib., 30c; 10 lbs., \$2.50.

Larger quantities at market prices.
CHILEAN ALFALFA-Is the old stand by. Many preferring it to Hairy Peruvian and other varieties. While it does not grow as fast it produces a finer grade of hay. Cattle preferring it to the others. It is much longer lived than the Hairy still producing paying crops. It will stand much colder weather than any other variety and is grown in every state in the Union. Lb., 30c; 10 lbs., \$2.70.

Write for special prices in large quantities.

We carry a complete stock of certified Chilean, Modoc, Arizona, Byron and Common Alfalfa seed, and all of it is the strongest American grown seed on the market. When ready to buy, write for our best prices.

MEDIUM RED CLOVER-This is the most important of all clovers and the standard everywhere for hay and pasture. It is known as Common Red or June Clover in many sections. Lb., 45e. Larger lots at market prices.

MAMMOTH RED, Or SAPLING CLOVER-Grows much larger and lasts longer than the conimon Red Clover: being a rank grower, it is largely used for soiling. Fifteen pounds to the acre. Lb., 45e; 10 lbs, \$3.80; not prenaid. Large lots at market rates.

A machine which should be on every farm. It is light, strong and durable, and with ordinary ca re will last a lifetime. It will suw clover, corn, and grass seeds and fertili\%ers of all kinds perfectly even, ald any desired quantity ner acre by folple directions on every machirie. prepait it eirlt 5 lins.

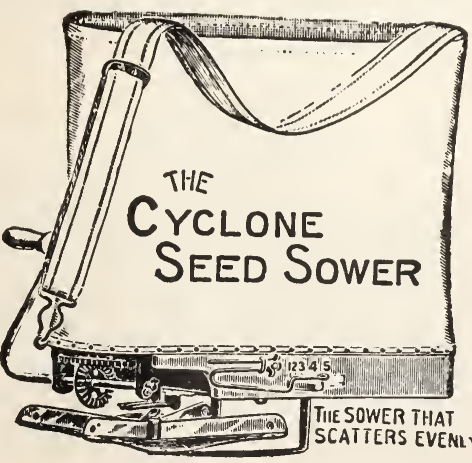

TIIE SOWER THAT
SCATTERS EVENL

ALSIKE-Succeeds best in cold, stiff soils and in marshy lands where it is too wet for other species; is very hardy and withstands severe cold: is a good honey plant for bees. lots at market prices. SIVEE'T CLOVER, BOKHARA Or BEE CLOVERwill grow on any soil and is invaluable for bee food. It is greatly relished by the bees and makes superior honey. Of great value as a fertilizer. Sweet Clover will furnish the soil with bacteria for the successful growing of alfalfa. It will make sandy loams fertile. Sow 10 to 12 lbs, per acre. Lb., 25e; 10 lbs., \$2.00, not prepaid.

Will sow all

kinds of grass and grain seeds from 4 to 8 acres per hour a t a common walking gait. such as wheat it will throw each side of the operator)

lighter seeds, GEAR of course, WillaND not be thrownFRAME So far. Weight MALLEAILE 8 lbs. Price, IRON

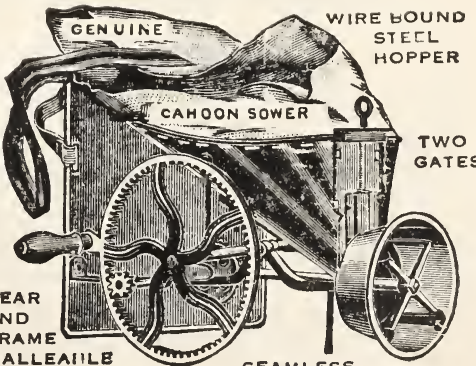

SEAMLESS DISCHARGER 


\section{Cover Crops}

One of the best and most economical ways of restoring worn-out soil or building up poor soil is by the use of nitrogen-gathering green cover-crops. It is necessary for the orchardist to use some covercrop to insure a profitable crop, and the following varieties are recommended for this purpose.

\section{OREGON VETCH}

\section{(Vicia sativa)}

Probably more Vetch is now planted for covercrop than anything else. The common Vetch is the variety used almost entirely in California, and is usually planted in the fall and plowed under the following spring. It is a pea-like plant, growing following spring. It is a pea-like plant, growing green matter than any other legume that will withstand the winter. Where planted for soil improvement, about 40 ibs. of seed are sown to the acre broadcast.

Vetch also makes splendid hay, but if intended to be sown for this purpose, some sort of grain should be mixed with it. This for the reason that the Vetch grows so tall it will fall over, and it is necessary to give it support. It is recommended that oats or barley be used with the Vetch where planted for hay, using about 60 pounds of one of planted for hay, using about 60 pounds of one of the former and 30 pounds of

PURPLE VETCH-Makes the quickest growth of any cover-crop and can be planted later. Makes the heaviest growth of any leguminous cover-crop known. The demand for this vetch is greater than the supply. Lb., 20e.

HAIRY VETCH-The true Winter Vetch. A forage plant which has proved of highest value. It succeeds and produces good crops on poor sandy soils. and grows to a height of 3 to 5 feet. It is exceedingly nutritious, is eaten with relish and may be fed with safety to all kinds of stock. Is the earliest crop for cutting, and a full crop may be taken off the land in time for the spring crops. It serves equally well as a cover crop, for pastures, hay, or as a soil renovator. In the far North sow in the early spring; in moderate climates sow from September to January, broadcast or in drills, at the rate of 1 bushel per acre, with $1 / 2$ to 1 bushel of rate of 1 bushel per acre, with $1 / 2$ to 1 bushel of
rye, wheat. oats. or barlev. Cut when the vetches are in full bloom. Lb., 15e.

\section{BURR CLOVER}

\section{(Medicago denticulata)}

This is our native Clover, and one of the best nitrogen-gathering crops that is known; it is by far the very best crop for poor or dry land, as it needs but little moisture. It is also very valuable for permanent pasturage and re-seeds itself very rapidly.

While some regard Bur Clover as a pest, it is. nevertheless, a most valuable soil-improving and winter grazing crop, growing luxuriantly all through the winter and until summer. This seed is sown at the rate of about 20 pounds to the acre. ib., 20e. Large lots at market price.

\section{YELLOW BLOSSOM CLOVER}

\section{(Melilotus Indiea)}

This variety of seed is now receiving special mention, particularly in southern California. It has wonderful nitrogen-gathering properties, and opens up the soil well for irrigation by reason of the big tap-root it sends into the ground. The seed is sown at the rate of about 20 pounds to the acre, and is more economical to plant than any other variety of seed used for soiling purposes. Lb., 10e. Large lots at market price.

PEAS, CANADIAN FIELD - These are usually sown with oats and cut when the oats head, but before the grain is ripe. For best results sow 40 lbs. of oats and 100 lbs. of peas to the acre.. Lb.. 15e.

\section{LADINO CLOVER}

\section{The New Dairy Pasture Crop.}

Probably you have been hearing or reading a lot lately about Ladino Clover. Although it is a comparatively new arrival on the Pacific Slope, it is already very popular as a dairy pasture crop, particularly in California and Oregon.

\section{Advantages of Ladino Clover.}

Ladino Clover is an ideal dairy pasture crop just as alfalfa is an ideal dairy hay crop. It will grow very satisfactorily on land that is not good for alfalfa. By that I mean it is an ideal crop to raise on shallow soil, on soil where there is a high water level or where alkali is present.

It continues to flourish even when pastured at the rate of four cows per acre during the growing season. Very glowing reports have come in from various sections telling how Ladino has turned unprofitable fields into highly productive grazing pastures.

\section{The Plant}

The Ladino Clover plant is very similar in appearance to ordinary white Dutch clover, but it grows more rapidly and becomes much larger. Its roots are comparatively shallow. They branch at the crown, just above the ground, and send out runners in all directions for three or four feet. These runners branch and take root, every few inches, at the nodes.

The stems, which lie close to the ground, are held by the many roots, and will not be pulled off or eaten by stock while pasturing. The ends of the stems, which grow as high as two feet, are not injured by pasturing or cutting.

\section{When to Plant Ladino}

Seemingly the best months for seeding Ladino are August, September, October, November, February, March, April and May. Land should be prepared the same as for alfalfa seed. Deep plowing pared the same as for alfalfa seed. Deep plowing any other cultivated crop, it may be simply disced and harrowed, so that a shallow seed bed will be made. You need sow only four to six pounds of seed to the acre. This makes Ladino a very economical crop to plant.

\section{Irrigating Ladino}

Although Ladino is not a particularly dry or "thirsty" plant, but is rather a hardy "rustler" capable of standing the hardest pasturage, it is necessary to keep the soil moist in order to get a satisfactory stand. This is especially true in soil containing alkali, which must be kept well watered.

\section{Suggested Grass Mixture With Ladino}

A number of dairymen have reported very good results from planting Ladino with other grass seeds. Such a mixture reduces the possibility of bloating. They have found the following mixture very satisfactory:

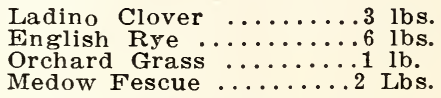

The Value of Good Seed.

Ladino Clover seed so closely resembles that of ordinary white Dutch clover that it is impossible even for experts to tell them apart. The buyer of Ladino should make sure that he is getting his seed from a thoroughly trustworthy source.

We sell only Certified Ladino Clover seed. Take no chances and be sure you are getting genuine Ladino Clover. Buying in large quantities direct from the producer, we are able to offer Certified seed at the following prices. (Subject to change without notice). Per lb., 70e; 50 Lbs. or over at 65e per lb. Freight or postage paid to your station. 


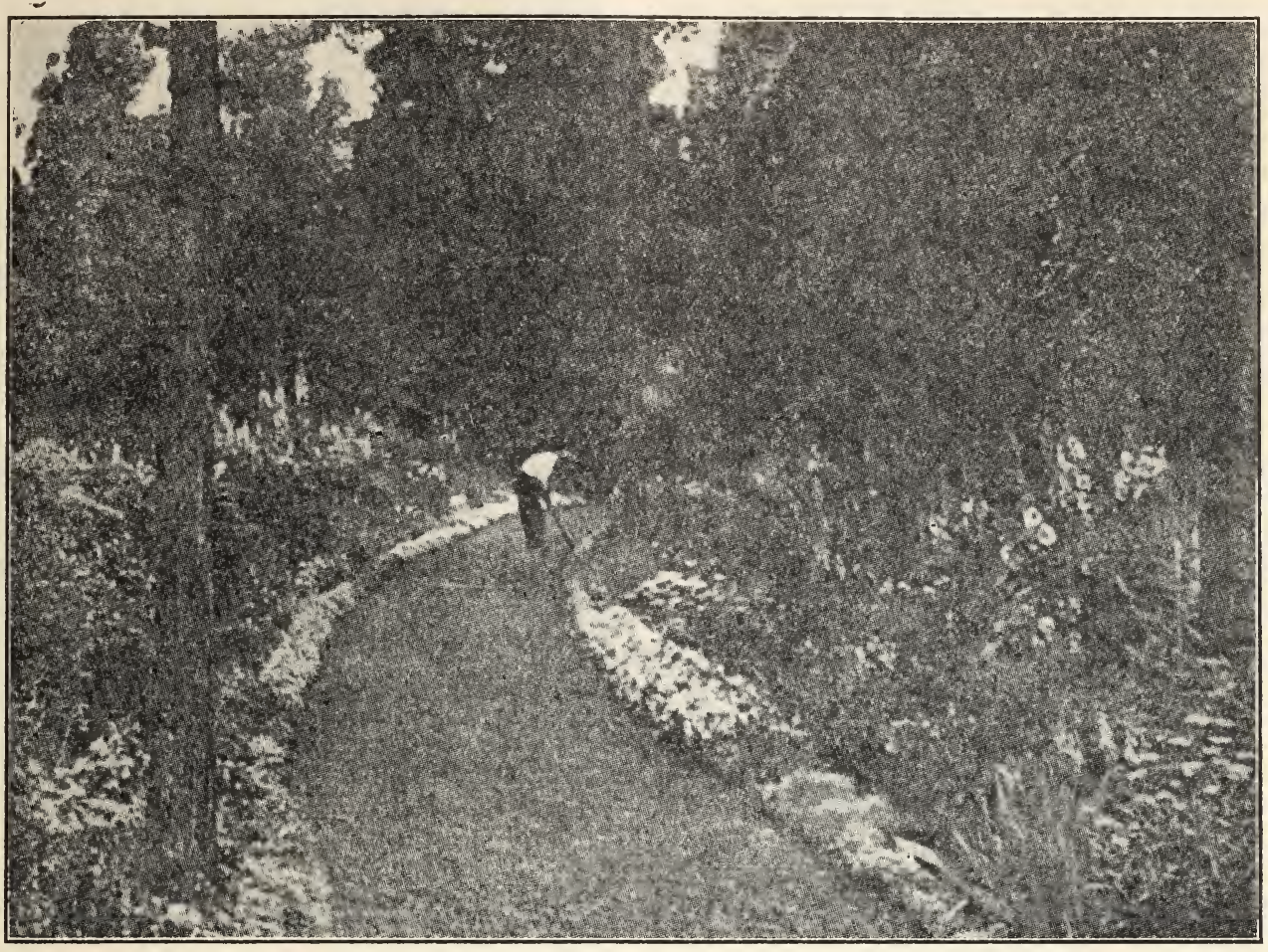

\section{Flower Seeds}

In listing our flower seeds for the new year we have endeavored to limit our list to those only of proven varieties, leaving out novelties that have not been proven. Our flower seeds are grown by one of the largest and best growers in the country and are shipped to us in bulk. We carry a complete stock of flower seeds at all times, putting up our packages from fresh seed as they are needed. Should you desire a flower that is not listed in this catalog, write us, and if we haven't it in stock we will endeavor to obtain it for you from a reliable source.

Tender or Greenhouse means the plant will not stand the least frost. All such must be planted late in spring (May) or in a greenhouse.

Half Hardy means the plant will stand any light frost, but needs protection against very cold weather. These should be planted in the spring (March and April), not in the fall.

Hardy means the plant will stand considerable frost, or practically all we have on the Pacific Coast. These may be planted in the fall or in the spring (October to May). If sown in the fall they will come into bloom earlier than if sown in spring, even if the plants do not make much progress during the cold weather.

Annuals are plants that bloom in the first year from seed, and the plant dies after one season.
Tender annuals must be sown in spring (April to June) and hardy annuals may be sown in either spring or fall (October to May).

Biennials are plants that bloom the second year from seed, and plant dies after blooming. In California, many of these will bloom the first year if sown early. Sow under same conditions as perennials.

Perennials are plants that bloom the second year from seed, and the plant lives and blooms during successive years. If sown in early spring (February to April 15) many perennials will bloom the first year from seed. Tender and halfhardy perennials are best sown in spring after frost is over (April 15 to June). Hardy perennials are best sown in late summer and early $f$ all (July to October) for next year's flowers. 


\section{ASTERS}

The Asters, in the beautiful double varieties, are unsurpassed for bedding and cut flowers. They are very profitable for the florist and also one of the most satisfactory for the home garden. The many delicate shades and beautiful colors, the size, form and long blooming season, all make for the great popularity of these charming flowers. Asters are very hardy and may be planted outroors as soon as the soil is warm and dry. You can start them indoors or in a cold-frame in January or February and transplant outdoors after killing frost danger is past. Plant in well prepared good garden soil in rows 18 or 24 inches apart; cover seed with $1 / 4$ inch fine soil firmly pressed down and when plants are 2 inches high, thin to 15 inches apart in row. Seeds may be planted in beds outdoors and transplanted when 2 or 3 inches high. Keep plants well watered in warm and dry weather, watering in morning and evening 2 or 3 times a week. For late flowering, seed may he sown in May or June. By disbudding, letting only a few flowers come on each plant, much larger flowers will form, as large as and more beautiful than ordinary chrysanth emums.

\section{BRANCHING COMET ASTERS}

Our new Giant Comet type of full doublebranching Asters is marvelous for size, beauty and full petals, making the most perfect and fullest flowers of the Comet type. Plants sturdy and vigorous, branching freely and showing scores of finest flowers. These are of extraordinary size, full double and of wonderful clear tones of colnr. Branching Comet. mixed, pkt.. 10c.

White, rose pink, crimson, purple. Fkt., 10e.

\section{IMPROVED CREGO}

Plants robust, about two feet high, Flowers large, double and well formed, of the Comet type, making a fine variety for all purposes

White, erimson, lavender, purple, azure blue, shell pink. Pkt., 10e.

\section{EARLY WONDER}

The best extra early variety. The flowers are of good size, quite double, and borne on good stiff stems. Pkt., 10c.

\section{THE CHINESE}

Petals are narrow, very long and gracefully reflexed. The outer petals show to their full extent. while gradually toward the center they bend and curl on each other in such magnificent disorder as to make the fluffiest aster we have ever seen. Pkt., 10c.

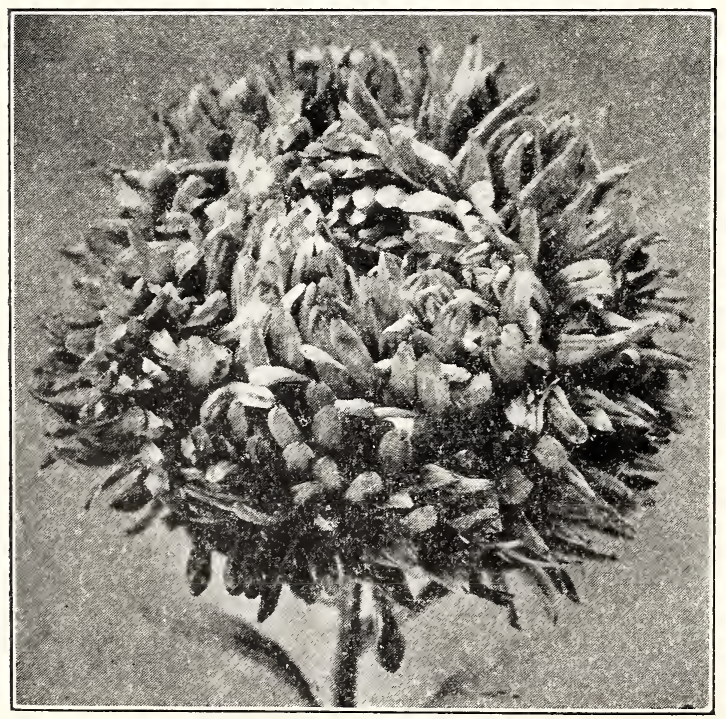

Branching Comet

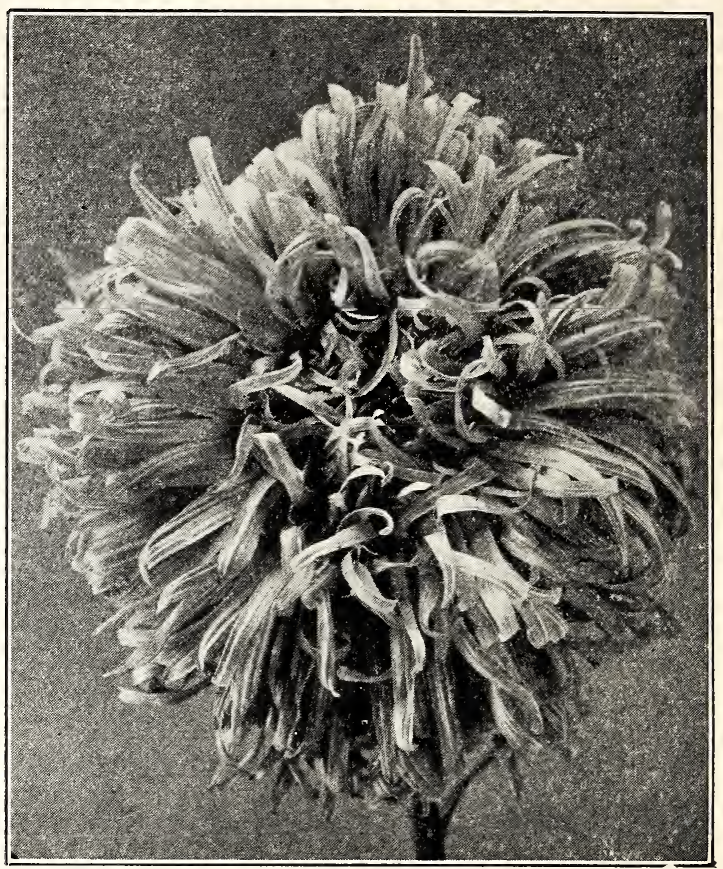

Giant Crego

IMPROVED GIANTS OF CALIFORNIA.

This type is rapidly becoming a general favorite especially for florists' use. We offer the following colors from reselected stock seed: White, Light Blue, Deep Rose, Dark Purple, Light Purple, mixed colors. Per Pkt. 10c.

IMPROVED CALIFORNIA SUNSHINE

It has long, strong stems which adapts it wonderfully well for cut flowers. Some of the blooms have twisted petals, some are quilled but all have a cushion center of a contrasting color. All colors mixed. Pkt., 10c.

\section{LATE BEA U'TY}

Plants about 2 to 3 feet high, of branching habit commencing to bloom in early September and lasting until destroyed by frost. Flowers large, borne on long and stout stems, from 18 to 24 inches. We offer the following: Carmine Rose, Crimson, White, Purple, Lavender, Mixed colors. Pkt. 10e.

\section{AURORA}

The center of the flower is bright yellow, with an outer circle of delicate blue, forming a very striking contrast. The plants are of robust growth, averaging two feet in height. Pkt., 15c.

\section{feet in height. Pkt.,}

The color is a deep yellow when first opened, and fades slightly as it ages. It can be described as of American Branching habit, height about two feet, filowers of good size and form, petals slightly incurved, but no trace of quills. Pkt., 15e.

\section{PERENNIAL OR MICHAELMAS DAISY}

This hardy perennial fills an important place in the hardy border. Height 30 inches. Blooms late in the season with masses of dainty and bright colored blossoms. Mixed colors. Pkt. 10c.

\section{HEART OF FRA NCE}

HEAR'T OF FRANCE-A rich dark red. The richest, most striking color and not to be found in any other aster. The plants grow about 2 feet high and are of a branching habit. Pkt., 10c. THE KING

In form the flower is entirely distinct from any other variety; petals somewhat resemble quilled varieties, but much larger and broader. Pkt. 10c. ACHILLEA

Ptarmica, "The Pearl," a fine hardy perennial orowing about 2 feet high, covered heads of double white flowers throughout the entire season. Fine for cutting; will flower the first year if sown early. Sow in boexs to transplant. Pkt., 10c. ACROCLINIUM (Everlasting)

A very pretty, half hardy double daisy-like flower, about one and one-half inches in diameter. Each flower-head is borne singly on a very long stem; leaves, narrow, alternate. Mixed, pkt., 10c. 


\section{AMARANTHUS}

These plants afford brilliant contrasts of color, being useful for tall borders, groups and foliage effects. The leaves and stems are of different shades of red, blended usually with green; two to three feet high. Seed may be sown in open ground early in spring, covering one-fourth inch deep; thin two to three feet apart.

TRICOLOR-Leaves yellow, red and green; well known as "Joseph's Coat." Hardy annual; 2 feet high. Pkt., 10c.

CAUDATUS (Love Lies Bleeding) - Produces long, drooping chains of brilliant colored flowers. Pkt., 10c.

\section{ARMERIA}

(Sea Pink)

Height 18 inches. Very useful in the hardy border and excellent for cutting, as the long-stemmed rose-colored flowers retain their brilliant appearance for a long while after being cut. Blooms early; valuable for spring gardening or rockeries. Pkt., 10c.

\section{ANEMONE}

Also known as Wind Flower. They are hardy perennials and are the first flowers to bloom each year. Are valuable for edging or massing and are profuse bloomers of beautiful colors. Grow 2 to 3 feet high, the cut flowers making beautiful bouquets. Caen Hybrids, mixed, Pkt., 10e.

\section{ARCTOTIS GRANDIS}

(African Lilac Daisy)

Large pearly white Marguerite-like flower, with delicate mauve center surrounded by a narrow golden band. The whole plant is covered with white down. Half hardy annual. Height 2 feet. Pkt.. 10c.

AGERATUM (Floss Flower)

A beautiful, hardy annual of neat bushy habit. The attractive feathery flowers borne in dense clusters are very useful for bouquets. Very desirable for outdoor bedding and borders, being covered with bloon nearly all summer. Mixed, Pkt., 10c; Blue Perfection, Pkt., 10c.

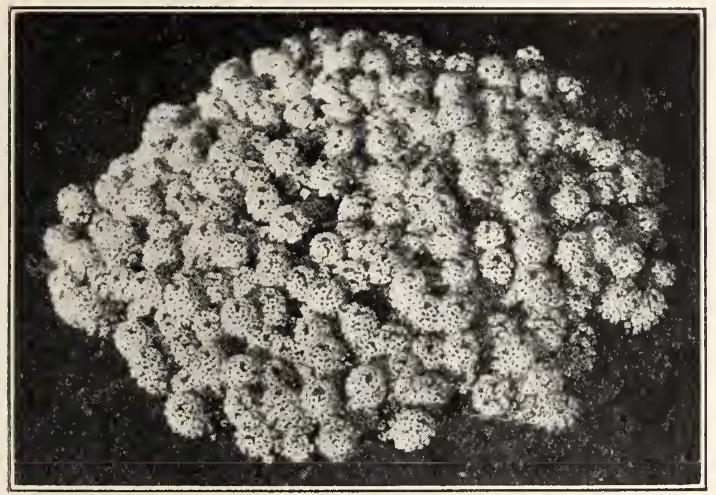

ALYSSUM

The annual varieties can be grown very readily either outdoors or in the house and by cutting back the plants properly an almost constant succession of bloom may be had. Seed can be sown in open ground very early in spring, or may also be sown outdoors in fall.

SWEET (Maritimum) - This very hardy annual for borders, edging or massing in small beds comes into bloom early in the spring, covering itself with clusters of trusses of small, pure white cruciform flowers. Pkt., 10c.

SAXATILE COMPACTUM (Basket of Gold)-One foot. May-June. Producing masses of golden flowers very early. May be planted effectively with Arabis. Pkt., 10c.

COMPACTUM LILACINUM (Lilac Carpet Plant) Distinct variety with delicate lavender flowers. Very dwarf. Pkt., 10c.

CARPET OF SNow (Little Gem)-Pure white, very dwarf and sweet-scented. The best whiteflowering border plant. Height 4 inches. Pkt., 10c.

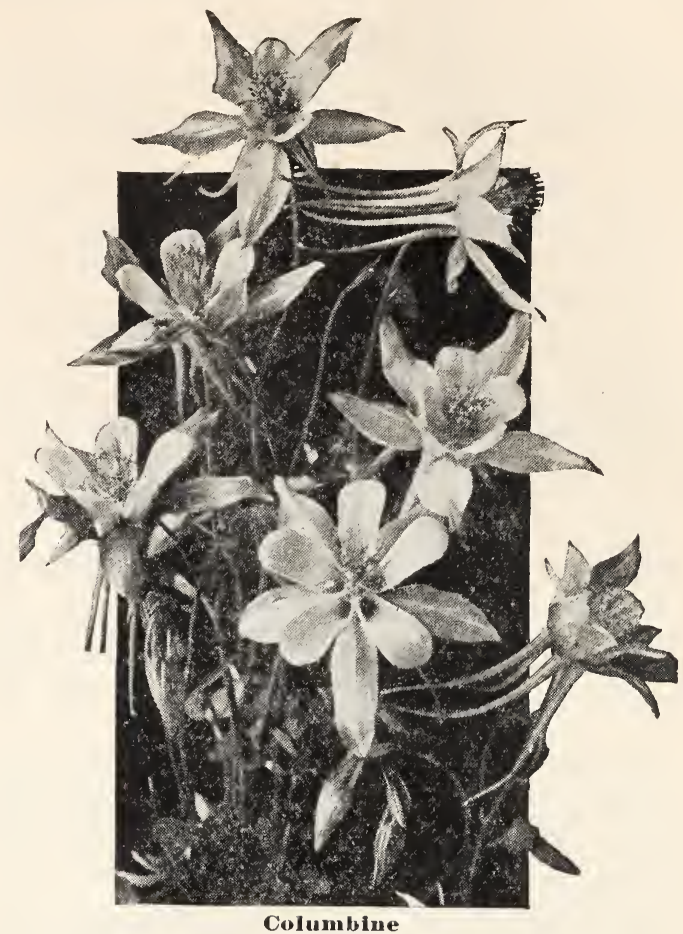

AQUILEGIA OR COLUMBINE

AMERICAN HYBRID COLUMBINE-The highest perfection attained in the development of this favorite flower. The plants are extremely robust with large handsome foliage; the flower stems often 40 inches in height, carrying magnificent clusters of immense long spurred single flowers which last a long time in bloom. The large unique, long-spurred flowers, gracefully hung on long stems, are not only brilliantly effective on the nlant. hut enirlly as desirable when cut for vase and house decoration. Pkt., 10c. Double Mixed, Pkt.. 10c.

\section{ANCHUSA}

Italica, Dropmore Variety, $5 \mathrm{ft}$. June-July. Beautiful gentian-blue flowers, one of the best perennials. Thrives best in partial shade. Pkt., 10c.

\section{ANTIRRHINUM OR SNAP-DRAGON}

This flower is next to the sweet peas in popularity. Flowers of the most brilliant colors, which remain in bloom from early in July until Frost. Seeds may be sown in a sunny situation the first part of May. If real early blossoms are desired they may be started in a box or hot bed and set out when danger of frost is past.

Copper King. Old Gold. Snowflake, The Rose, Defiance Scarlet. Purple King. Mixed colors Pastel colors. Pkt., 10e.

TOM THUMB-An excellent mixture containing all shades of these showy flowers. Splendid for edging and showy display. Height 10 inches. vixed. Pkt.. 10c.

\section{ARGEMONE GRANDIFLORA}

\section{(The Prickly Poppy)}

2 feet. Lovely plants with an ornamental foliage and laroe havidsome poppy-like flowers, snowy white, filled in the center with golden stamens, very beautiful. Pkt. 10c.

\section{ADELUMIA (Alleghany Vine)}

CIRRHOSA-16 feet. The feathery foilage is like the Maidenhair Fern. Delicate rose pink and white flowers cover the plant. Pkt., 10c.

\section{AUSTRALIAN PEA VINE}

(Dolichos lignosus) - A very rapid growing vine, with pretty foliage and rose and purple pea-shaped flowers. Valuable for covering up fences quickly: stands the heat well. The seed should be soaked in hot water about 12 hours before sowing. Pkt., 10c. 


\section{ABRONIA}

UMBELLATA (Sand Verbena)-Pretty little plants resembling the Verbena in their style of growth. The flowers are very fragrant and especially so in The flowers are very fragrant, and especially so
the evening. Rosy lilac, 6 inches. Pkt., 10c.

\section{AGROSTEMMA (Rose of Heaven)}

Exceedingly pretty and graceful flowers. Red, white, and red and white flowers. Pkt., 10c.

\section{ANTHEMIS (Marguerite)}

These hardy Marguerites are most satisfactory perennials, succeeding in the poorest soil bui needing full sun. The flowers are yellow.

KEIVAVI (Hardy Iarmuerite). 2 feet. Daisylike yellow blossoms. produced all Suminer. Excellent for cutting. Pkt., 10e.

\section{ADONIS AESTIVALIS}

\section{(Flos Adonis: Pheasant's Eye)}

Flowers crimson and small. Seed should be sown in the Autumn. Height, 1 foot. Pkt 10e.

\section{ARABIS (Rock Cress)}

Charming dwarf Spring-flowering plants of easy cultivation; valuable for beds, edgings. They do well in any soil, but need plenty of sun. Pkt.:-Oe.

\section{ALONSOA (Mask Flower)}

Warscevicy-A free flowering annual plant with bright vermillion scarlet flowers with golden stamens; is a half hardy annual. grows 2 feet tall and thrives best in a sunny situation. Sow the seed in boxes in early spring and transplant when danger from frost is over. Pkt. 10c.

\section{ABUTILON (Flowering Maple)}

Beautiful shrubs with maple-like leaves and large bell-shaped flowers in white. rose, yellow and red colors. Half hardy perennial. Sow the seed in boxes and transplant when well started. Extra fine mixed, Pkt., 15e.

\section{ASPARAGUS}

Plumosus Nanus (Lace Fern) $3 \mathrm{ft}$. The bright green sprays surpass the Maiden-hair Fern in grace and delicacy of texture. The hard seeds need soaking and bottom heat to sprout them. Pkt., 10e.

Sprengeri (Emerald Feather). A very elegant foliage plant for hanging baskets, etc. Pkg. 10c.

\section{BALSAM (Camellia)}

The old Fashioned Flower Touch-Me-Not or Lady Slipper

The old and familiar Touch-Me-Not or Lady Slipper improved until those familiar with the old forms would hardly recognize the large waxy flowers with their elegant shades of color and variegations as belonging to the same class. They grow luxuriantly all through the West with little attention in any good garden soil, and will repay one for the little trouble. Sow in open repay one for the little trouble. Sow in open ground after danger of frost is past, or earlier effect plants should be set about 18 inches apart.

ROSE FLOWERED-Mixed Colors-Pkt., 10e.

TALL DOUBLE MIXED-Pkt., 10e.

\section{BALSAM APPLE}

Quick growing climber, ornamental foliage, interesting and valuable fruits which are esteemed throw the seeds a considerable distance, a source of amusement for the children. It is often used with other climbing plants for shading porches, balconies and outdoor seats. Pkt., 10c.

\section{BUDDLEIA}

(Butterfly Bush or Summer Lilac)

A snall shrub bearing exquisite tapering spikes of lilac mauve flowers; require same protection as roses during Winter. Plant in Spring.

VARIABILIS VEITCHIANA- $3 / 8$-feet. July- September. Mauve. Pkt., 10e.

\section{BALLOON VINE (Love in a Pot)}

Interesting climber from the East Indies. A general favorite. Rapid growing annual climber delighting in warm weather. Small white flowers. followed by inflated seed vessels like miniature followed by inflated seed vessels like miniature balloons. This most interesting climbing plant is
fine for shading porches or outdoor seats and the novelty of its little balloon-like fruits never wears uff. Try a packet of it this year. Pkt., 10c.

\section{BRACHYCOME \\ (Swan River Daisy)}

A free flowering annual, covered during the greater part of the summer with a profusion of pretty blue or white flowers, suitable for edging small beds or pot culture. Pkt., 10e.

\section{BEAN-SCARLET RUNNER}

The well-known rapid-growing annual climber, producing bright red flowers, from July to September. The foliage being dense, makes it splendid for porches or any location where shade is desired. Pkt., 10e; 1/4 1b., 25e.

\section{BROWALLIA}

GRANDIFLORA-Most beautiful of all Browallias. Grow only about 1 foot high; form dense little bushes covered with abundance of delightful little bushes covered with abundance of
extra large sky-blue flowers. Pkt., 10e.

\section{BLEEDING HEART}

The beautiful lyre flower-one of the most ornamental of spring flowering plants, with elegant green foliage and long drooping racemes of heartshaped flowers. Perfectly hardy. Plant from November to April. Pkt., 15c.

\section{BARTONIA AUREA (Blazing Star)}

Handsome, with downy foliage; fragrant, large, golden yellow flowers, which open in the evening. Thrive in any soil; height about 3 feet. Pkt., 10c.

\section{BEGONIA}

The tuberous rooted Begonia is one of the finest greenhouse plants. Sow in early spring, in fine sterilized soil, leaf-mold and sand. Cover the seeds very slightly and place a sheet of glass over each pan or flat until the young plants are up. Prick off singly as soon as large enough to handle and place in small pots when ready, potting into the larger sizes as they fill the smaller with roots. Pkt., 15e.

\section{BRYONOPSIS}

LACINIOSA-10 feet. An ornamental climber of the gourd family, bearing green fruit which changes in color to bright scarlet striped white. Pkt., 10e.

\section{CACALIA}

Coceinea-A handsome, free-flowering little plant, owing to peculiar form of the flower is sometimes called Tassel Flower or Flora's Paint 'Brush. Scarlet bloom. Pkg., 10e.

\section{CREPIS}

Hawkweed-Showy star-like semi-double flowers of bright rose color. Bushy plant attractive in the garden and useful for cutting purposes. Pkg., 10c.

\section{CALANDRINA}

Cmbellata - Hardy perennial of trailing habit, producing brilliant crimson flowers. Excellent for rockwork and sunny situations. Blooms the first season. Pkg., 10c.

\section{COLLINSIA}

Bicolor: Slender, graceful annual $11 / 2$ to 2 feet high, earing clusters of lilac flowers prettily marked with white, violet and purple. Pkg., $10 \mathbf{}$ 


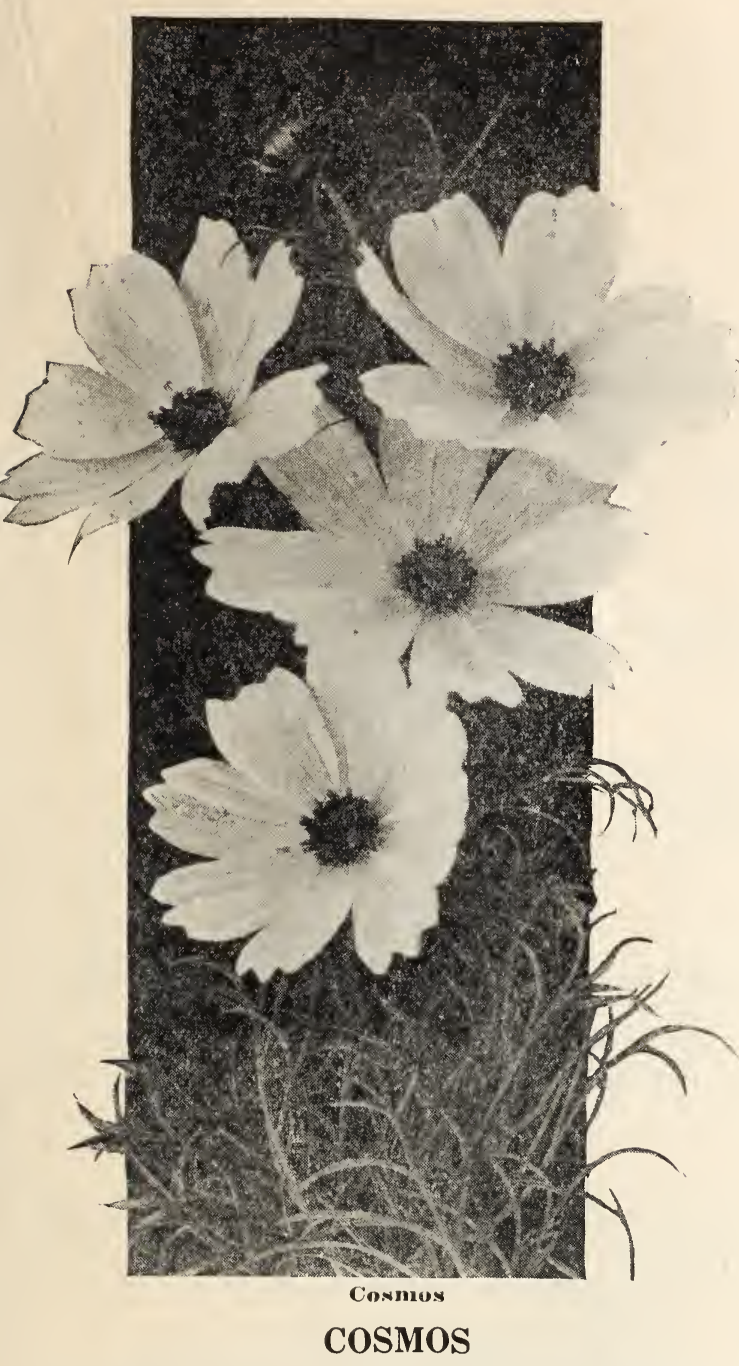

A hardy and rapid growing annual, forming brush-like plants with feathery green foliage, four to six feet high, covered with large flowers.

Sow outdoors early in spring in rather light soil, not too rich, and preferably in a sunny situation.

HOLLWOOD STAR-The flowers are Pink, Red and White, borne on long stems. Useful for cut flowers. Pkg., 15e.

Early Express Pink-Extra early, plants grow about 2 to $3 \mathrm{ft}$. high and are covered with medium sized bright pink flowers. Pkg., 10c.

EARLY FLOWERING CosMos - These early flowering strains are about four feet high and bloom profusely four to six weeks earlier than the giant sorts. Mixed colors, pkt., 10c.

LATE GIANT COSMOS-This variety should be planted in late spring and summer for fall blooming. The plants often reach a height of six feet and make a splendid background.

Late Mammoth White, Pink, Crimson, Mixed; Pkt. 10e. Klondyke, Orange, Pkt., 10e.

\section{DOUBLE CRESTED COSMOS}

This new type of Cosmos is unique and exceedingly pretty. The flowers are of good size, with fully double centers and an outer row of broad ray petals. The plants are vigorous, attaining a height of 4 feet, and are covered with blooms. This is the best of all Cosmos for cut flowers, lasting well in water, and the dainty colors are most attractive for either garden or table decoration. Give Cosmos the full sunshine for successful growth. Pink, Crimson and Mixed. Pkt., 10c.

\section{CACTUS}

CAC'TUS-Saved from the best and most distinct species. Finest mixed. Height $1 / 2$ to $4 \mathrm{ft}$. Pkt., 10e.

\section{CALCEOLARIA}

Especially fine annual for greenhouse and window decoration. The immense pocket-shapedflowers are uniquely spotted and blotched, and borne in the greatest profusion through Spring and Suminer. Plant from February to May-or from August to October. Mixed-Choicest colors-Large Pkt 50c.

\section{CARNATIONS}

The Carnation has long been prized as a hardy border flower. Being hardy, free-flowering, and easily grown either in flower-beds, borders, or easiy grown elther in flower-beds, borders, or of our summer flowers and a favorite with everyone. Plants raised from seed bloom more profusely than propagated plants, and are therefore to be preferred.

CHABAUD'S MIXED-A remarkable strain raised by a Carnation specialist in southern France. Blooms in five months after being sown, and continues to flower indefinitely in the greatest profusion. Yellow, Red, Pink, White, Mixed, Pkt., 10e.

\section{CANDYTUFT-(Iberis Umbellata)}

Candytuft is one of the most prized garden annuals. Easily grown from seed and does not need transplanting. Fine for cut flowers.

Mixed, Pkt., 10e.

\section{CELOSIA OR COCKSCOMB}

Free flowering, highly ornamental plants of easiest culture, growing best in rather light soil. Blooming season June to November. They make grand border plants and the dwarf sorts are attractive for pot culture.

PLUMosa (Feathered Cockscomb)-Plants grow 2 to 3 feet high and produce feathery plumes of vivid colors. Pkt., 10c.

CRISTATA (Mammoth)-Comb-like flowers of large size and rich color. Plants tall and strong. Ikt., 10c.

CELOSIA CHILDSII (The Chinese Woolfower) Plants grow two to three feet high. the blonms starting early with a central globular head which often reaches the immense size of two feet in cir cumference. Scores of branches are thrown out each bearing a ball of wool. Scarlet, pink and yellow. Pkt., 10c.

\section{COLEUS}

(Perennial) - These beautiful and ornamental foliage plants, producing the most attractive colors, are most interesting subject to grow fronl seed. are a most interesting subject to grow fron seed. ors as it grows day by day is wonderful. Choice ors as it grows

\section{CAMPANULA or CANTERBURY BELLS \\ (Perenuial)}

Large, bell-shaped flowers of exquisite colorsblue, pink and white. They are very ornamental plants with perfect masses of bloom, often bearing 100 to 200 blossoms on one spike. Sow see.l in the open ground, cover lightly and thin plants to stand 12 inches arjart.

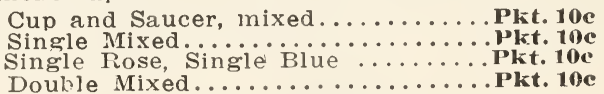

\section{CANARY BIRD VINE}

A rapid growing climber of the Nasturtium fam ily, with handsome, finely cut foliage, producing an abundance of bright, canary-yellow, bird-like hlossoms from . July until frost. An excellent winter window vine. Height, fifteen feet. Pkt.. 10e.

\section{CANNAS}

One of the most effective of show foliage plants. The seed should be cut off or filed at one end Plant indoors one-half inch deep in rich soil and keep moist until sprouted.

FINEST MIXTIRI-Contains many large. flow ering varieties. Pkt., 10e. 


\section{CLARKIA}

Beautiful hardy annuals with rose colored, white and purple flowers, in delicate but very brilliant shades. The plants are about one and one-half to two feet high and are profuse bloomers.

Sow in light, warm soil, as early in the spring as the ground can be worked, or if planted in August they will bloom the following summer. Double mixed. Pkt., 10e.

\section{CINERARIA}

Cinerarias are easily grown from seed in the greenhouse. The large heads of brilliant daisy-like flowers of many colors, usually sharply margined and with dark eye, are very desirable in pots. The plants are often as broad as high and the velvety leaves are shaded on the under side.

HYBRIDA, CHOICEST MIXED-Large flowering. Pkt., 25e.

\section{COREOPSIS}

LANCEOLATA, GRANDIFLORA-A most showy flower with its cloud of bright yellow blossoms from June till fall. The plant grows 3 to 4 feet tall with very long stemmed blossoms that have few equals for cutting. Pkt., 10c.

\section{COBAEA}

A rapid-growing climber with beautiful dark green foliage, bearing on graceful stems large bell-shaped flowers, green at first but rapidly changing to a beautiful deep violet blue.

SCANDEN5-Large, bell-shaped. Pkt., 10c.

\section{COIX LACHRYMAE}

\section{(Job's Tears)}

Curious ornamental grass with broad corn-like leaves and seeds of a light slate color. Valuable for winter bouquets with everlasting flowers. Strings of handsome beads are made from the seeds. Hardy annual; three feet high. Pkt., 10c.

\section{CASTOR BEAN}

\section{(Ricinus)}

Tall majestic plants for lawns and driveways; with broad, beautifully lobed, palm-like leaves of glossy green, brown or bronzed metallic hue and long spikes of scarlet, or of green, prickly seed pods. Makes a rapid growth in rich soil. Sow seed outdoors after danger from frost is over, preferably in light rich soil, or for earlier over, preferably in light rich soil, or for earlier development each plant should have at least four feet each way. Tender annual, six to fifteen feet high. Pkt., 10e.

\section{CYPRESS VINE}

A popular climber noted for dainty fern-like foliage and star-shaped flowers. Finest mixed. Pkt., 10e.

\section{CYCLAMEN}

Popular free flowering, bulbous plants for house culture, producing graceful orchid-like flowers during the fall, winter and spring. Colors range from white to darkest crimson, with all intermediate shades. Show Mixture, Pkt., 25c.

\section{CENTAUREA}

Centaureas embrace a number of species, some being grown only for their foliage. Sow the seed early in boxes and transplant in March or in the open in April. All make excellent cut-flowers, except the white-leaved sorts. Height $11 / 2$ to 2 feet. CYANUS (Bachelor's Button; Bluebottle; Corn-
fower)-Of easy culture. Sow the seed where it is to remain and thin plants to 3 to 4 inches apart. Blue, Pink, Mixed colors. Pkg., 10e.

IMPERIALS (Royal Sweet Sultan)-The plants are very strong and bear giant flowers on stiff long stems: excellent for cutting, lasting a week when cut. Three feet tall.

Mixed (only). Pkt., 10c.

\section{CONVOLVULUS}

Minor-Dwarf or Bush varieties. 1 ft.-Are very showy and beautiful annual for flower beds and borders, also rockwork; they bloom for a long period and delight in sun. Mixed, all colors, Pkt., pec

\section{CHRYSANTHEMUMS}

Showy and veryeffective garden annuals of easy culture, doing especially well in our state. The plants grow from 12 to 14 inches high, have fine delicate foliage, and produce flowers in great abundance. Splendid for cutting.

SINGLE MIXF.D-Lovely daisy like flowers. Pkt.,

10c. 10c.

DoUBLE MIXED-Showy double flowers. Pkt.

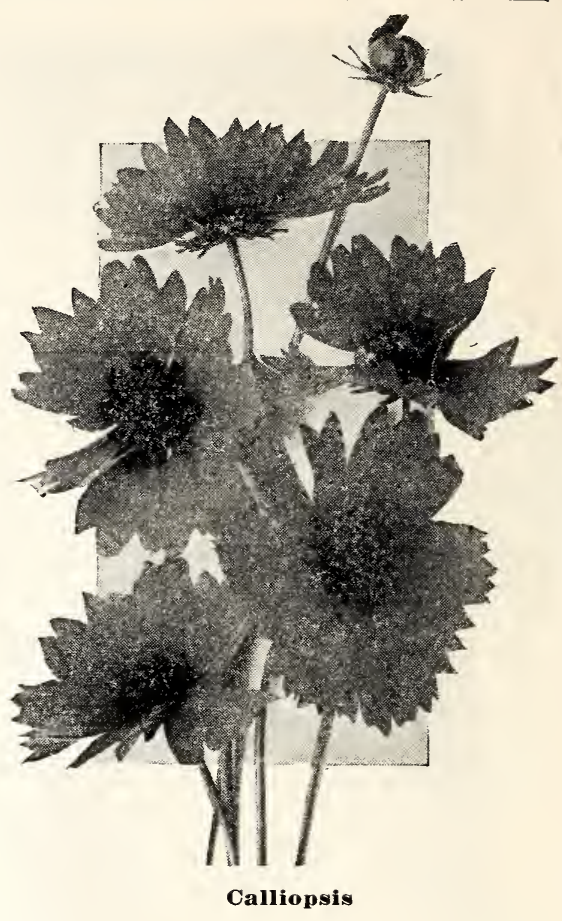

CALLIOPSIS

Many most showy flowers are common and grow anywhere without trouble or care. Of these is the Calliopsis.

SINGLE MIXED-Mixture of annual varieties. Many shades of yellow, red and brown. Pkt., 10e.

NEW DOUBLE-A beautiful and charming new type of the annual Calliopsis. Pkt., 10c.

\section{CLEMATIS}

A very fine hardy climber; leaves bright and glossy green: flowers small and haw thorne scented, and just covering the plant when in bloom. Excellent for covering trellises or fences.

PA ICULata-White, Pkt., 10c.

\section{CLIANTHUS}

Dampieri (Glory Pea of Australia)

2 feet. Clusters of bright red flowers with black spot. Pkt. 15e.

\section{CARDINAL CLIMBER}

A strong, rapid grower, attaining a height of thirty feet or more, with beantiful fern-like lacinated foliage, covered with fiery cardinal-red flowers from midsummer till frost. The flowers are about $11 / 2$ inches in diameter, and are borne in clusters of five to seven blossoms each. It delights in a warm. sunny situation and good soil. Pkt., 10e.

\section{DIMORPHOTHECA}

\section{Ringens}

The individual flowers are large pure white on the inside with a very conspicuous blue ring around the center or eye of the flower, which adds greatly to its beauty. Pkt., 15e.

\section{CHEIRANTHUS}

Siberian Wallfower- $1 \mathrm{ft}$. A beautiful rock plant Dazzling fiery orange flowers, on stems about a foot high. Best used as a biennial as it frequently blooms itself to death. Pkt., 10c.

\section{CERASTIUM}

Tomentosum - Hardy perennial invaluable for rockeries and edgings; foliage silver grey. Height 6. Flowers purplish lavender. Pkt., 10e. 


\section{DIMORPHOTHECA-(African Daisy)}

AURANTIACA-A rare, extremely showy and greatly improved annual which has become a general favorite. The bushy plants grow about fifteen inches high. The flowers are often three inches across, of unique, rich, glossy orange gold color. Blooms until late fall. Pkt., 10c.

\section{DOLICHOS-(Hyacinth Bean)}

A tender climbing annual; flowers profusely and in clusters of white, purple and lilac shades. The flower spikes are followed profusely by ornamental seed-pods. Height 10 to 20 feet. Mixed colors. Pkt., 10c.

\section{DAHLIAS}

It is not generally realized that most beautiful Dahlias may be grown and flowered in late summer and autumn from spring-sown seed. Many of them, differing from any of the named varieties on the market, and some from seed are equally beautiful, the production of novel forms and combinations of colorings being most interesting.

SINGLE GIANT PERFECTION-This variety produces flowers of immense size of the most bewildering variety of color. Pkt., 10c.

DOUBLE LARGE FLOWERING-Double show and fancy sorts. Pkt., 10c.

\section{DATURA-(Angels Trumpet)}

A vigorous-growing plant producing immense flowers ranging in color from white to pure yellow. They are well suited for borders or for specimen plants on the lawn, or for the center of ornamental beds. Pkt., 10e.

\section{DIANTHUS, OR PINKS}

Few flowers can equal these in beauty and profusion of bloom. They comprise many beautiful markings, rich and varied in colors. The plants bloom until frost.

DOUBLE MIXED-All the most beautiful and showy double varieties. Pkt., 10c.

SINGLE MIXED-Fringed flowers of various colors. Pkt., 10c.

DOIBLE CLOVE PINKS-Double and semidouble varieties in beautiful colors. Mixed, Pkt., 10e.

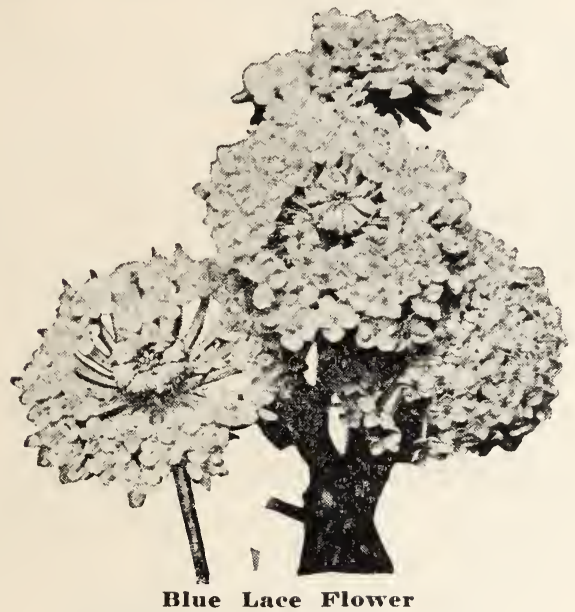

DIDISCUS COERULEA

BLUE LACE FLowERS - A delightful annual which produces flowers of a sky-blue color. The flower itself ranges from $11 /$ to 2 inches in diameter, and in formation is similar to the Scabiosa. Should be started under glass or in a seed bed, and then transplanted to its permanent position. It is especially fine for forcing under glass. Half shady position is best. Pkt., 10c.

\section{ESCHSCHOLTZIA-(California Poppy)}

A hardy annual, with fine-cut, feathering foliage and beautiful, velvety, cup-shaped flowers. Seeds may be sown in fall and any time thereafter until the following April, where plants are to remain, as they do not transplant easily. Height, 2 feet. CAI.IFORNIA-Large, pale yellow. Pkt., 10c. Mixed colors, Pkt.o 10c.

RAMONA-Novelty. This variety stands out as a distinct and very charming type in the frilled class. It is single but the frills give it the appearance of a semi-double. Pkg., 10c.

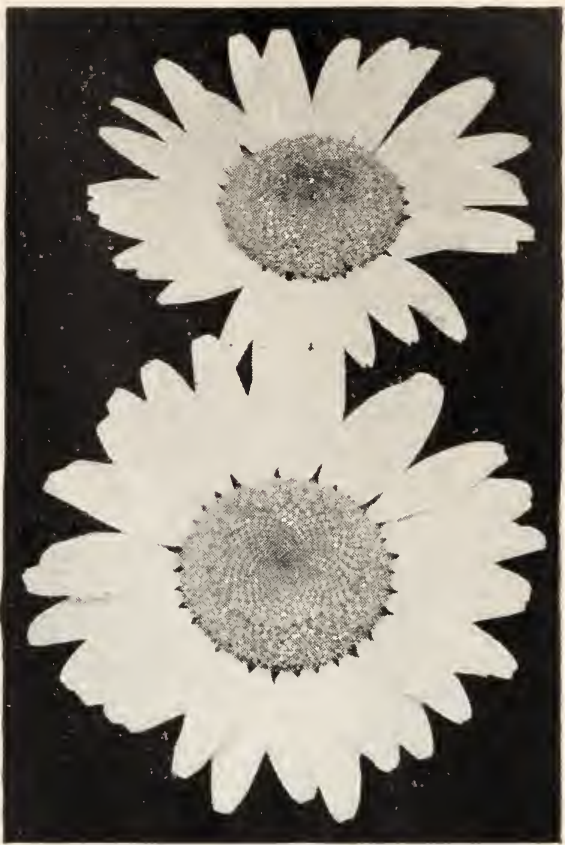

DAISY, SHASTA

Our choice Alaska variety with flowers of purest glistening white with broad overlapping petals, one of the finest and most attractive flowers crown These flowers are much lor mon daisies, often 5 inches across, and make fine
cut flowers with long stems, lasting a week or two after being cut. Grows 2 to $2 \frac{1}{2}$ feet high and excellent for beds, borders, clumps and cut flowers. It lasts for years and makes fine borders and clumps. Pkt., 10c.

\section{DAISY, DOUBLE ENGLISH (Bellis Perennis)}

The true English Daisy, perfectly hardy and suited to cool, rather moist locations. Blooms in earliest spring and late fall. Sow seed early in boxes or shallow drills; then transplant to permanent location. Treat same as violets. Can be flowered through the winter if placed in boxes in pits or planted out in cold frames. Flowers very double. Plants spread rapidly in rich soil and last for years. Grow 6 to 10 inches high.

Mammoth Double Mixed, Pkt. 10c.

\section{EVERLASTING FLOWERS}

See Acroclinium, Gomphrena, Helichrysum.

\section{DELPHINIUM-Perennial Larkspur}

These handsome, stately border plants produce long bold flower spikes ranging in color from the palest sky-blue to the darkest shades of indigo and violet, and are unrivaled for producing blue effects in the summer border.

Belladonna, light blue, Pkt. 10c; Bellamosum dark blue, Pkt., 10c; Cardinal, red, Pkt., 10c: Mixed colors 10c.

HOLLXHOCK STRAIN-The flowers are large, truly double, well-placed on long, pyramidal spikes, their sturdy growth and general appearance reminding one of a Hollyhock. Mixed colors. Pkg., 15c.

\section{EUPHORBIA}

Half hardy annuals suitable for beds of tall growing plants or mixed borders; the flowers are inconspicuous but the foliage is very ornamental. Sow February to May.

heterophyLLA (Annual Poinsettia, Mexican Fire Plant) - The plants grow 2 to 3 feet high, of branching habit, with smooth, glossy, green leaves which become a bright scarlet in summer. Pkt. 10c. 


\section{FORGET-ME-NOT-(Myosotis)}

Hardy perennial of easy culture. Blooms first year from seed. The flowers are small and starshaped, borne in clusters on long stems.

ALPESTR IS-Blue. Pkt., 10e.

CYNOGLossuM, Amabile-This annual was recently introduced from China. It is very hardy, and of easy culture. It grows on tall, graceful branches from 18 to 20 inches. Pkg., 10c.

\section{FOUR O'CLOCK-(Marvel of Peru)}

Plants are covered for months with innumerable silky flowers of the most ravishing colors, and exhaling a delightful perfume. It is an evening bloomer.

TOM THUMB, YELLOW LEA VED-Mixed colors. A new dwarf strain of great beauty. Grows only twelve inches high and each plant is a compact mass of lovely yellowish leaves which in evening are hidden by hundreds of gay blossoms. Pkt., 10c.

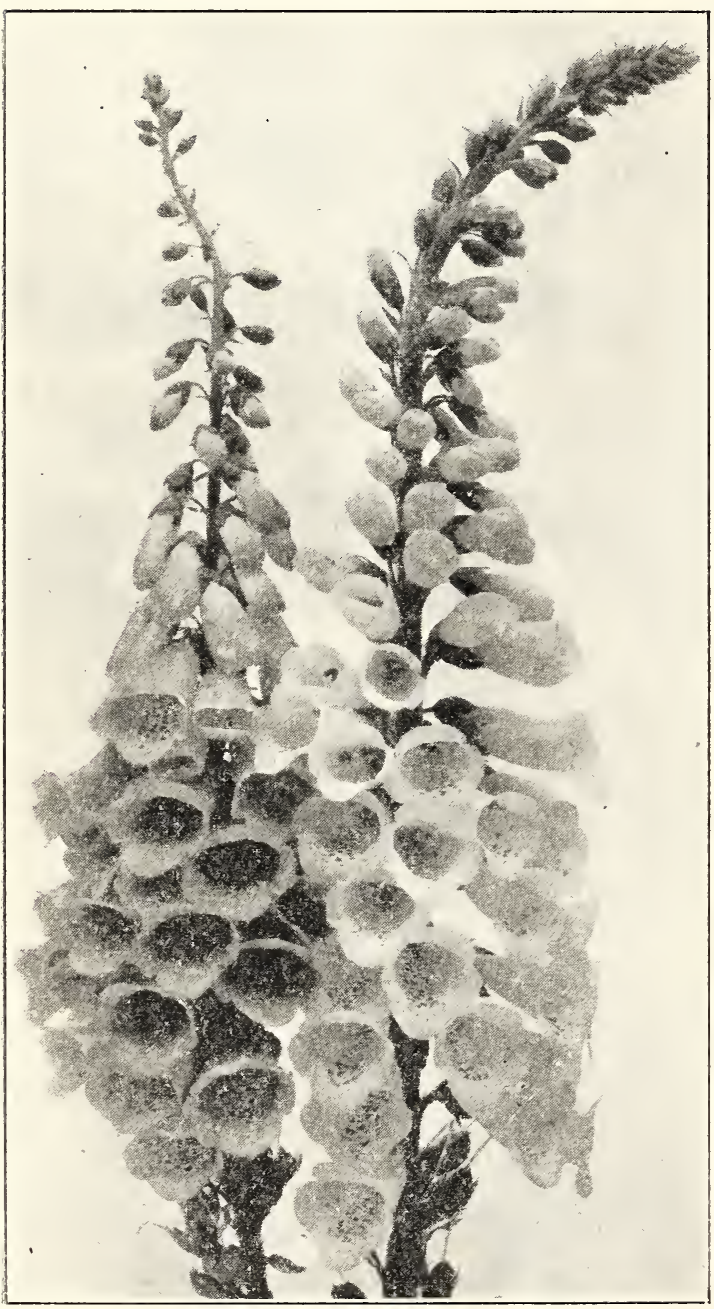

\section{DIGITALIS-(Foxglove)}

Hardy perennial, blooming the second year from seed. The bell-shaped flowers are borne on long spikes, and come in shades of purple, lavender rose and white, all spotted lightly inside. Thrives well in cool, shady locations.

Mixed. Pkt., 10c.

\section{FREESIA}

- These dainty little popular flowers may be grown from seeds or bulbs. They fiower very early in the Spring and are one of the most delightfully fragrant flowers in cultivation. Freesias are easily grown from seeds and will bloom the following Spring if sown in the Fall.

Purity-White. Pkt. 10c.

Hybrid Ragionieri (Rainbow)-A pleasant mixture of pastel shades. Pkt. 10e.

\section{GERBERA (Jamesonii Hybrids)}

Large daisy-like blossoms with flower stems rising to a height of about two feet. Is also called Transvaal Daisy. Colors range from white to crimson, pink, rose, yellow and lilac shades. Flowers both Summer and Winter. Start carefully under glass and grow in a sandy, well drained soil if possible. Pkt. 15e.

\section{GERANIUMS}

An old garden favorite and its popularity has not diminished with the years. They are generally grown from slips but they will produce almost as easily from seed and we offer an assortment of mixed varieties, giving different shades in coloring. The seeds should be started indoors early in the spring. The geranium is probably the best known and most admired of any garden flower and the geranium bed is always a beautiful sight and you may expect flowers from early summer until frost.

CHOICE MIXTURE-Seed saved from large flowering varieties and will produce a mixture of colored blooms. Pkt., 15e.

\section{GOMPHRENA-(Globe Amaranth)}

A showy annual everlasting with clover-like heads. Mixed, white, red and pink. Pkt., 10c.

\section{GYPSOPHILA}

Free flowering, elegant plants. The annuals are dapted for rustic rockwood and edging. The perennials are perfectly hardy, succeeding in any garden soil.

PANICULATA (Baby Breath)-Perennial. A mass of the finest leaves and branches, covered with tiny white, star-shaped flowers. Pkt., 10c. Ec.

ELEGANS, Grandifiora-Carmine. Pkt. 10c

ELEGANS, Grandifiora-Crimson. Pkt., 10e.

\section{GOURDS-(Ornamental Climber)}

Well-known climbers, with odd-shaped fruit. Fine for training over fences or trellises, and always sure to attract the attention of the children, who love to play with the pretty striped and oddly crooked fruits. Mixed Gourds, Pkt., 10c.

\section{GEUM}

Mrs. Hugh Bradshaw; a showy hardy perennial with large double brilliant colored flowers which are borne on long stems. Blooming from spring until fall. Pkt., 10c.

Lady Stratheden-A very striking double yellow flower, very large. Pkt., 15e.

\section{GODETIA}

Handsome, showy annual about one foot high, of dwarf, compact growth; bear freely flowers 3 to 4 inches across, of exquisite colors. Mixed rarieties and colors.

Tall Single-Finest mixed colored. Pkg., 10c.

Tall Double-Grandiflora mixed colors. Pkg., 10c. 


\section{GAILLARDIA-(Blanket Flower)}

The flowers are dazzling and brilliant in colors, red and yellow predominating. Easy to grow from seed, and will produce in profusion a continuous supply of exquisite flowers on long stems. Blooms from early spring until late fall.

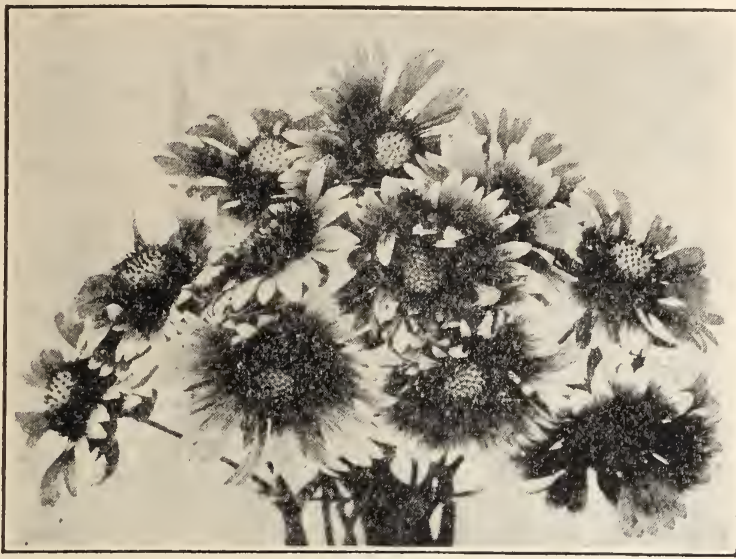

Gaillardia

\section{HUMULUS-(Japanese Hop)}

A rapid-growing ornamental climber covering arbors, trellises, etc., in one season. The foliage resembles the common Hop and is very luxuriant, making a dense vine. Will stand extreme heat and remain green until frost. An annual. JAPONICUS-Green foliage. Pkt., 10c.

\section{HOLLYHOCKS}

Our Hollyhocks are far superior to the old single and semi-double sorts. Once established they grow and bloom freely for years. Sow in early spring, in boxes or beds, and when 6 to 8 inches high transplant to their permament place in open ground, placing them $1 \frac{1 / 2}{2}$ to 2 feet apart. Give them rich soil in a moist location, or where plenty of water can be given and they will grow 5 to 8 feet tall. The Hollyhock is an old-established flower and perhaps no other flower leaves such an impression as does the Hollyhock. The beautiful long spikes filled with tissue paper-like blooms, 3 inches across artistic background or tall border.

SINGLE MIXED COLORS, Pkt, 10e DOUBLE MIXED COLORS, Pkt, 10e DOUBLE ROSE. . .

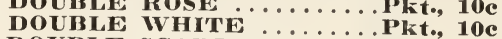
DOUBLE SCARLET ….......Pkt,, 10e DOUBLE YELLOW.........Pkt, 10e

Will thrive in poor soil and are not affected by extremes of weather. Plants of strong growth with grayish foliage. Height, 18 inches.

Grandiflora-Mixed colors, Pkt., 10e; Double, 10e. Double tips is most attractive. Pkg., ioc.

\section{GILIA}

Hardy annual California wild flower. Sow the seed in the open either in the fall or spring.

CAPITATA, "Blue Gilia"-A slender branching plant $11 \frac{1}{2}$ to $21 / 2$ feet high; flowers light blue in dense globular heads. Pkt., 10c.

\section{HELICHRYSUM}

\section{(Straw Flower)}

Everlasting flowers suitable for mixed borders. The flowers retain their shape and color for years, but it is necessary to gather them before they are fully expanded, and hung upside down to dry. Useful for winter bouquets, decorating, etc. Annual, Choice Mixed Colors, Pkt., 10c.

\section{HIBISCUS}

(ROSE MALLOW) -3 to 5 feet. Noble, shrub-like plants, with handsome green foliage, bearing throughout the summer large bright flowers, from 3 to 5 inches in diameter. August-September Very hardy. Suitable for garden and indoor use when cut. Pkt., 10e.

\section{HELIOTROPE}

A universal favorite on account of its delicious fragrance. Excellent for cutting. Seed sown in early spring will make fine plants during summer. Partial shade suits it best. Annual. Mixed colors, Pkt., 10e.

\section{HEUCHERA EANGUINEA (Coral Bells)}

A low-growing plant with heart-shaped leaves which form a low clump 6 to 8 inches high and bearing during the summer; loose graceful sprays of coral-red flowers in great profusion; suitable for the border or rockery. Pkt., 10c.

\section{HELIOPSIS PITCHERIANA}

\section{(Orange Sunflower)}

A hardy perennial growing 3 to 4 feet high, beginning to flower early in the season and continuing the entire season. The flowers are deep golden-yellow about 2 inches in diameter; of thick texture and very graceful for cutting. Pkt., 10e.

\section{HEDYSARUM}

Coronarium, Red-French Honeysuckle. Attractive border plants with showy racemes of deep red, fragrant flowers. $2-4 \mathrm{ft}$ Summer. Need sun and light, well-drained soil. Seeds, Pkt., 10c.

\section{HELIANTHUS}

SUNFLOWER-We have in this class plants of very stately growth with immense gaudy flowers, fine for wild gardens, along fences or garden walls.

DOUBLE CHRYSANTHEMUM FLOWERED-PKt., 10e.

RED SUNFLOWER-Some flowers are a rich chestnut-red color, others tipped with yellow and others slightly washed with red. The flowers vary in size, some being very large. Plants grow from 4 to 8 feet. Pkt., 10e.

STELLA-Large golden-yellow petals, small, dark center. Pkt., 10c.

IAROON PRINCE-The color is true maroon, single and dwarfgrowing. . Pkg., 10c.

Double

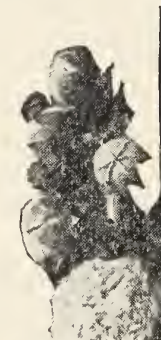




\section{ICE PLANT}

MESEMBRY A NTHEMUM CRYSTALLINUM - A most interesting plant, with delicate succulent almost transparent branches and leaves. Of drooping habit, adapted to baskets, vase work and rockeries. Prized for its singular foliage, which looks as though covered with particles of ice. .Pkt., 10c.

\section{KUDZU VINE}

(Pueraria 'Thunbergiana)

Jack-and-the-Bean-Stalk Vine. The most remarkable rapid-growing hardy perennial extant. In rich soil will grow 40 feet in one season. Three months of its growth will equal five years of most vines. Starts into growth slowly, but after three or four weeks grows almost beyond belief. Leaves in four like lima bean; color, dark green; texture in shape like lima bean; color, dark green; texture we know of nothing its equal. Pkt., 10c.

\section{KOCHIA-(Mexican Burning Bush)}

A splendid and novel plant. An easily grown annual suitable for all parts of the West. Sown thinly in spring when leaves begin to appear on the trees, it soon forms a cypress-like hedge of symmetrical form and of lively green color; by midsummer it attains a height of about 3 feet and on approach of cool weather the whole plant becomes a deep red. One of the most novel and interesting plants that can be grown from seed in teresting plants that can be
any flower garden. Pkt., 10e.

\section{LANTANA}

Tender perennial, growing from 2 to 3 feet high, bearing verbena-like clusters of flowers in orange, white, rose and other colors. Good for bedding. Choice mixed. Pkt., 10e.

\section{LINARIA-KENILWORTH IVY}

Very pretty hardy evergreen creepers, well adapted for growing in pots or for covering walls or crevices. Cymbalaria, Pkt., 10c.

\section{LINUM}

(Grandiflora Rubrum "Searlet Flax"-A very effective and showy bedding plant having fine foliage and delicate stems. The flowers are brilliant scarlet crimson. Plant about one foot high. Pkt., 10c.

Perenne, Sibericums Blue. Pkg., 10c.

\section{LOBELIA}

Exceedingly useful plants for edging flower beds, their free-blooming qualities and brilliant shades of blue and white making a pleasing contrast to the masses of reds and yellows so prevalent in bedding. They are splendid for hanging baskets, pot culture, etc. All are annuals except Lobelia cardinals, which is a hardy perennial.

CRYSTAL PALACE COMPACTA - Dark blue. For borders and bedding. Pkt., 10c.

\section{LARKSPUR}

Exceedingly popular and free flowering hardy annuals, orowing $11 / 2$ to 3 feet high, their lon spikes of flowers on long stems rendering them of exceptional value for cutting purposes. They are of long continued bloom and very bright and showy. Sow in the Fall or Spring.

Dark Blue, white, Light Blue, Purple, Red, Lilac, Mixed colors. Pkt., 10e.

La France, Salmon-pink.. Pkt., 10c.

Los Angeles, rich salmon ground, overlaid with a brilliant and pleasing rose. Pkt., 15e.

DOUBLE STOCK FLOWERED-A very striking tall variety with splendid spikes of beautiful double flowers; height, $2 \frac{1 / 2}{2}$ to 3 feet.

\section{LATHYRUS}

HARDY SWEET PEAS-Showy, free-flowering. hardy perennial climbers for covering old stumps, fences, etc., continually in bloom; fine for cutting. Similar to the regular Sweet Peas but they bloom longer. Pkt., 10c.

\section{LUPINS}

One of our most attractive and easiest grown native flowers. The plants grow 2 to 3 feet high and have handsome spikes of flowers which are fine for cutting. If the plants are not allowed to go to seed they will flower for several months in the spring. Annual Mixed-Pkt., 10e.

\section{LYCHNIS}

A genus of handsome and highly ornamental plants of easy culture, strikingly effective in mixed flower shrubbery borders. H. P.

Chalcedonica-Scarlet, 2 feet, Pkt., $10 c$.

\section{LEPTOSYNE (Stillmani)}

$1 \frac{1}{2}$ feet. One of the quickest annuals, blooming within five weeks from date of sowing, and the golden-yellow flowers continue in perfection for a long period. Excellent for cutting. rkt. 10c.

\section{MATRICA RIA}

Feverfew-3 ft. nest, small double white and yellow quilled flowers, well adapted for bedding and cutting. Perennial. Pkg., 10e.

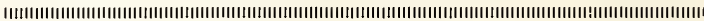

Our flower seed list has been carefully revised, some new sorts added, and all the inferior kinds omitted, so that there is nothing in the list but what is worthy of cultivation, and if reasonably cared for will give satisfaction. Our aim is to

offer nothing but the best and surest to please, a condensed list of leading kinds, and not the most bewildering and extensive list of varieties. No garden or lawn, whether large or small, is complete without a flower bed grown from Knox's Select Flower Seeds.

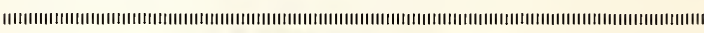

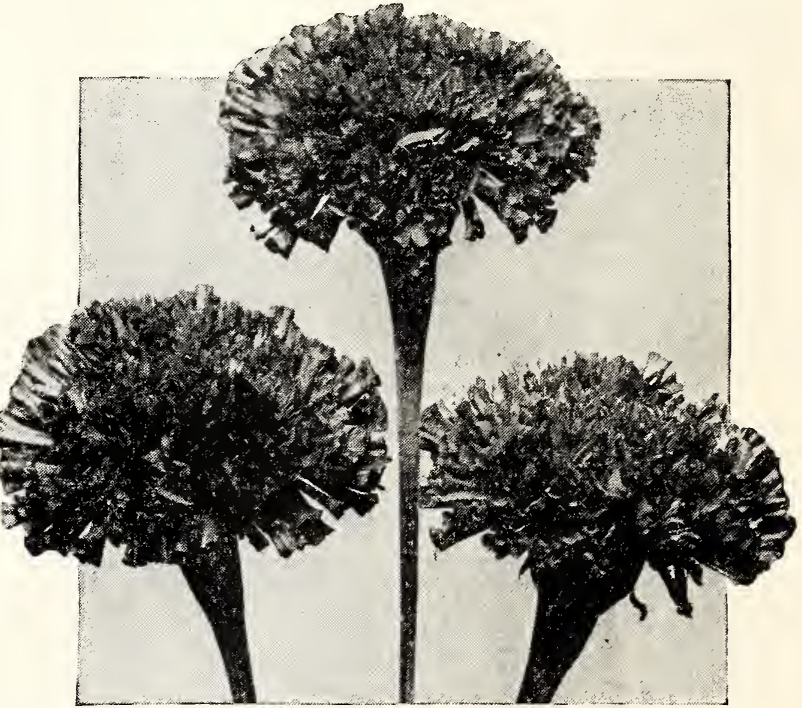

\section{MARIGOLDS}

The African varieties are the taller in growth, and produce large self-colored blossoms. The French varieties are smaller, some of them beinc elegantly striped and spottedd. The dwarf-growing kinds make extremely handsorne borders, being neat compact plants and remaining in full ing neat compact plants and remaining in full in open border, or earlier, in a cold-frame, and the young plants transplantedd late in the spring to where they are to remain. They succeed best in a light soil, with full exposure to the sun. Annual

TALL DOUBLE AFRICAN, MIXED-Extra large flowers, grows 15 to 30 inches tall. Various shades of yellow and orange. A bed of these will please you. Orange King, Lemon Queen. Pkt., 10c. DW Rather small, highly colored. Pkt.. 10c.

LEGION OF HONOR-Flowers rich golden yellow, marked with velvety brown. Best for edging. Pkt., 10c. 


\section{MAURANDIA}

Slender grower and abundant bloomer. Elegant Gloxinia-like flowers. Pkt., 10e.

\section{MIMULUS}

Tigrimus - Superb spotted and tigered strain, large flowered. Mixed. Pkt., 10c.

Cardinalis (Scarlet Monkey Flower) Rich dark red. Pkt., 15e.

Moschatus (Musk Plant)-Small yellow flowers, attractive for pots or baskets. Foliage musk scented. Pkg., 10e.

\section{MOON FLOWER}

The Ipomeas (Moonflowers) are popular everywhere as climbers for shade on porches, trellises and arbors. They make a rapid growth and a dense shade, protecting porches from the hot rays dense shade, protecting 20 feet high in good soil, branching freely, and at night and during cloudy days are covered with large flowers. Seeds should be planted after all danger of frost is past, where plants are to stand, about 10 inches apart. They can be planted earlier in pots in the house and transplanted when 6 inches high. The seeds are very hard, and to insure germination cut or file through this hard outer shell before planting.

Giant Blue, Giant White, Giant Pink, Heavenly Blue, annual, sky blue flowers. Pkt., 10c.

\section{MIGNONETTE}

By its sweet yet delicate odor the Mignonette has, for many years, endeared itself to every true lover of flowers. Fragrant as the violet, constantly in bloom, and easily grown, the modest Mignonette is found not only in the greenhouse of the millionaire, but in many a lowly garden and window box. Seed sown early in the garden will give flowers all through the summer and fall. The finest spikes of bloom are produced during cool, moist weather. For winter blooming, seed is usually sown in pots and brought on in succession, keeping the growing plants in a cool room

SWEET-(Reseda Odorata Grandifora) - A well known fragrant plant. Pkt., 10c.

\section{MORNING GLORIES-(Ipomoea)}

Free flowering, beautiful climbers with rich and varied colored flowers; very useful for covering lattice work, verandas, etc., where they are exceedingly effective. Soak the seed for several hours in warm water before planting.

IMPERIAI JAPANESE-They are beyond ques tion the handsomest of all Morning Glories. Of the easiest culture; can be sown in the open ground in a warm and settled climate. The foliage is luxuriant, distinct and varied, green, silvery and yellow leaves; many are mottled light and dark green, white and gray. The giant flowers are beyond description; the self or solid colors range from snow white to black purple, an endless number having flowers spotted, marbled, striped, flaked, splashed, etc. Pkt., 10e.

TALL, MORNING GLORY-The old favorite in all colors, mixed. Pkt., 10c.

\section{NEMESIA}

Hardy annual. This flower is obtainable in numerous shades of beautiful colors, and when grown in mass form, gives a fine effect. Sow in a seed bed early in the Spring and transplant.

Strumosa Suttoni--Mixed colors, height 15 inches. Pkt. 10e.

\section{NICOTIANA (Flowering Tobacco)}

A half-hardy annual, growing 3 feet high, with slender, tubular flower. Belongs to the tobacco family. Requires plenty of room in the garden. Pkt. 10e.

\section{NEMOPHILA (Baby Blue Eyes)}

A hardy California annual growing about 6 inches high. Has small cup-shaped exquisitely colored blossoms about one inch in diarnetor. Plants are of dwarf, spreading liabit, of eagy Plants are of dwarf, spreading liabit, of easy culture and makes a very
a bed or border. Pkt., 10c.

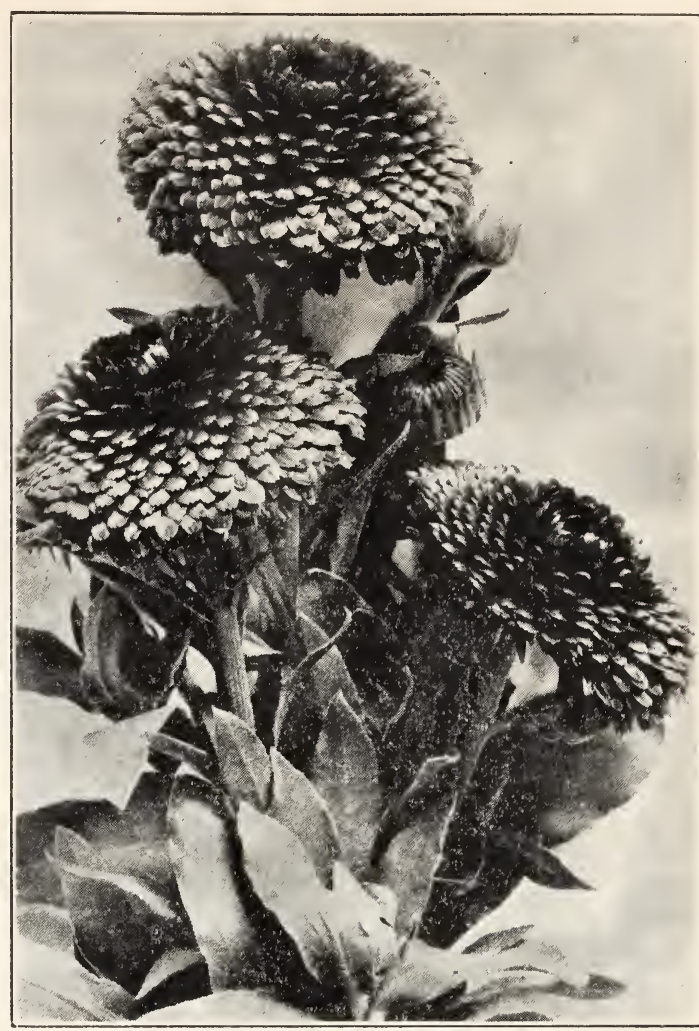

\section{CALENDULA MARIGOLD}

ORANGE KING-Bears giant flowers sometimes 3 inches in diameter. Color pure orange. Pkt., 10e.

Lemon Queen-Like the above, but of pure lemn. Pkt., 10c.

Double Mixed-A good mixture of 8 or 10 different shades of yellow and orange; some clear colors aird some shaded and striped. Pkt., 10c.

Campfire-Deep orange, blooms are flat and very large. Pkt., 10e.

Radio-Medium-sized orange flower with quilled r comet petals, curled and twisted, borne on medium length stems. I'kt., 15e.

\section{NIGELLA DAMASCENA}

\section{(LOVE-IN-A-MIST)}

This is one of our prettiest old-fashioned annuals. It will grow well under adverse weather conditions and withstands considerable heat and drought. Fine for the border, beds, or cutting.

DAMASCENA, DOUBLE MIXED-A mixture of rich Cornflower-blue and pure white flowers. Easly grown and sure to bloom anywhere. Always admired. Pkt. 10c.

\section{PORTULACA}

(ROSE MOSS)-A low spreading plant with fernlike leaves of a dark green color. It prorluces an abundance of bright flowers in all colors. It will thrive in hot sun where other plants refuse to thrive in hot sun where other plants refuse to grow and will stand an unusual amount of
drought. They begin to bloom in early spring and continue a mass of bloom until frost.

Double Mixed, extra fine quality. Pkt., 10e.

Single Mixed Colors. Pkt., 10c.

\section{PRIMULA MALACOIDES-(Primrose)}

It is quite hardy and is one of the best winter flowering plants we have. It is also well suited for pot culture. The flowers are of a delicate shade of lilac. Seed sown in August produces plants which flower through the winter months. Pkt., 25c. 


\section{NASTURTIUM}

These may be termed everybody's flower. No flower garden is complete without them. They furnish a never failing display of brilliant bloom all through the season. Sow in any good garden soil. Thin tall sorts six inches apart, and ten inches for the dwarf varieties. No such brilliant range of shades and colors has ever been seen before in Nasturtium mixtures. They please every one who plants them and are sure to satisfy you if you want the best there is to be had. Nasturtiums are as easiiy grown as any other flower and the dwarf varieties make the most beautiful beds, borders, edging, and porch boxes, while the tall varieties are unsurpassed to cover stumps, flower stands, low fences, and unsightly places. It is doubtful if among the plants classed as annuals there is any other of the summer blooming varieties which combines in so great degree the ease of culture, beautiful flowers of showy colors, profusion of bloom from early summer until killed by frost, and general excellence as to the Nasturtiums. very rich soil tending to make rank leaf growth. very rich soil tending to make rank
Hot weather has no injurious effect.

TALL OR CLIMBING VARIETIES-Pkt., 10c;

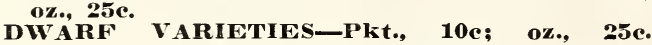
PASSION FLOWER (Passiflora)

A half hardy perennial climber, shedding its leaves in winter. A very satisfactory climber of immense growth, as it will cover a porch or small cottage in one summer. Pkt., 10c.

\section{PHLOX DRUMMONDII}

For beds and massing, nothing can surpass these beautiful annuals. They produce immense trusses of large, brilliant flowers of numberless hues throughout the summer. This strain has beautiful round petaled flowers, larger than in the older sorts; showy and constant. Pkt., 10c.

\section{STAR PHLOX}

A decidedly unique variety. With the petals of all other Phloxes are entire, in this variety they are partly fringed and partly toothed; the central teeth of the petals are five or six times as long as the lateral ones, and project like little spines, giving the flowers a regular star-like form. The beauty of the flower is enhanced by a white margin which borders the edges of the petals. There are many distinct colors. Best Varieties Mixed, Pkt., 10c.

PHLOX DECUSSATA-("Perennial Phlox") - This splendid, free flowering perennial is deserving of a place in every garden. The plants grow about 3 feet high and produces large heads of flowers of the most beautiful shade. Sow the seed in the fall in seed pans and afterwards transplant. All colors, splendid mixed. Pkt. 10c.

\section{PHACELIA}

CAMPA NULAIRA- 8 in. Very beautiful annual, producing a terminal raceme of intense gentianblue flowers with conspicuous white anthers. Pkg., 10c.

TANACE'TIFOLIA-18 in. Large compact head of pale mauve flowers. Valuable bee plant. Pkt., 10c.

\section{OXALIS}

Oxalis (Shamrock, or Wood Sorrell)

OXALIS- (Shamrock, or Wood Sorrel). Delightful little plants for edging, hanging-baskets and rockwork. 10

TROPAEOLOIDES-Yellow. Height 1-4 ft. Pkt.

\section{POINCIANA}

Gilliesi (Bird of Paradise)

The blossoms are of a rich golden yellow about $21 / 4$ inches in diameter, produced in large trusses, the most striking feature being the long, incurving stamens and pistils of a beautiful bright crimson color. Seed should be soaked in warm water and started indoors or under glass in a light sandy soil. Pkt., 25.e.

\section{PLATYCODON GRANDIFLORA (Japanese Bellflower)}

P. A giant Bellflower growing 2 feet tall covered all summer with large, steel-blue flowers. Pkt. 10c.

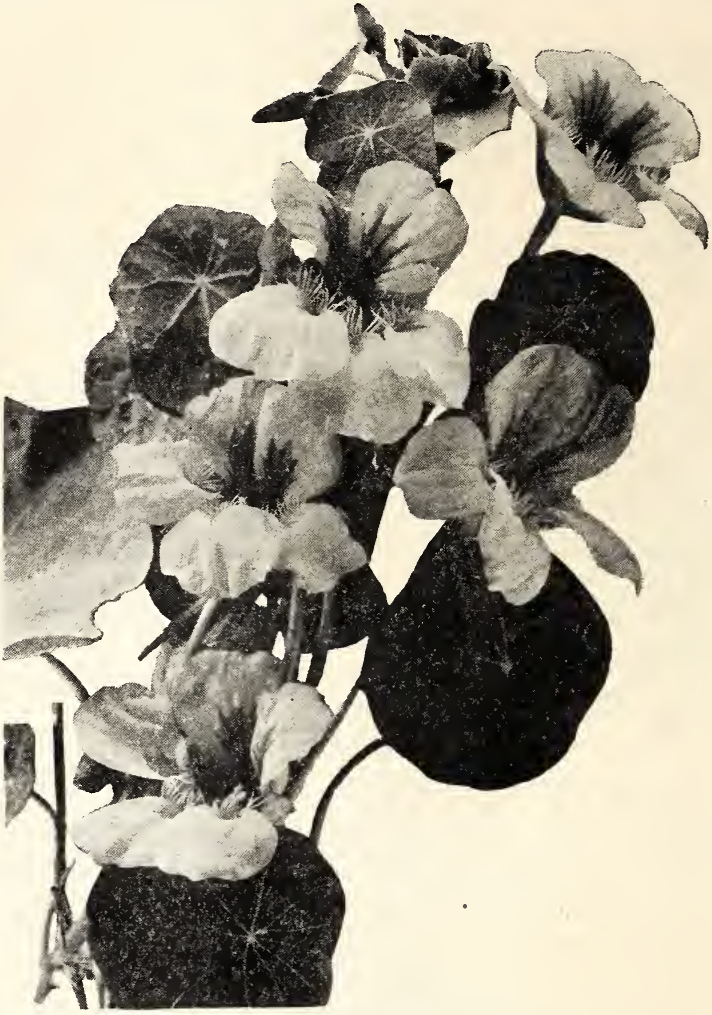

PHYSALIS FRANCHETI

(Chinese Lantern Plant)

Has bright yellow or scarlet seed-pods. The fruit inside the pod is sometimes made into preserves, Pki. 10

\section{PRIMROSE}

VERIS, IIXEL-The Oxlip, bearing bright yellow flowers in umbels. 6-9 in. Seeds, Pkt., 10c.

\section{POPPIES}

DOUBLE CARNATION - FLOWERED - Annual Fringed; colors are dazzling. Mixed, Pkt., 10c.

SHIRLEY - Annual. The range of color, extending from white through delicate shades of pink, ing from white through delicate shades of pink, rose and carmine to deepest crimson.

ORIENTALE POPPY-A charming summer flow ering hardy plant producing nuinerous leafy stems about $2 \frac{1}{2}$ feet high, with large cinnabar red flowers, having a conspicuous black blotch on each petal; exceedingly showy. Pkt.. 10c.

NUDICAUIA (Ieeland Poppy) -15 inches. MayAugust. Mixed. Elegant free-flowering plants bearing flowers in abundance all summer. Seeds

TÜLIP (Glaucum)-Large tulip-shaped flowers of dazzling scarlet: not unlike a Scarlet von Thol Tulip. Pkt. 10c.

HUNNEMANNIA. (Santa Barbara Ponpy)-Golden yellow. The plants grow into a shrubby bush and produce their large cup shaped flowers 3 in. across on stems 12 in. long. Pkg., 10c.

AMERICAN LEGION-A dazzling orange-scarlet of enormous size, borne on long, stems. Pkt., 10c.

\section{PENTSTEMON-(Beard Tongue)}

The flowers are borne in graceful spikes. The plants are herbaceous. and bloom from early summer until frost. The flowers are white, blue, scarlet, crimson, yellow, etc. Mixed, Pkt. 10c.

\section{PYRETHRUM}

PAIVTED DAISY-Very showy flowers of easy cultivation; valuable for cutting. The daisy-like blossoms borne in great abundance and a variety of colors. One of the best hardy perennials. Pkt., 10c.

GOLDEN FEATHER - Fine compact habit of growth, with bright yellow foliage, largely used for edgings, Pkt., 10e. 


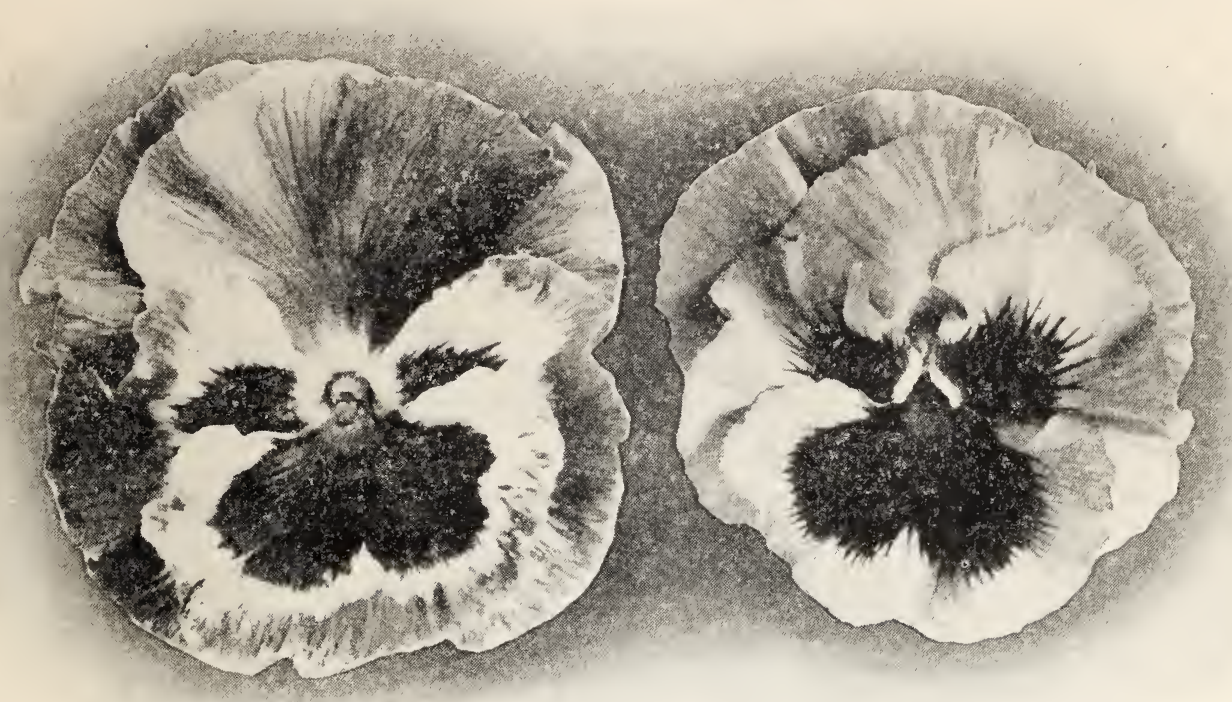

PANSIES

These magnificent giant Pansies are without a doubt the most wonderful pansies of the day, with a robust vigor unknown in any other strain. These blossoms are almost four inches across and are of a most wonderful variety of colors and variegations. They bloom from two to four weeks earlier than any other variety of Pansies. It is impossible to paint a word picture that will do justice to these flowers. You will never regret it, if you have them in your garden or porch box.

Pansies thrive best in a moist, sunny location, and in rich loamy soil. Seed should be sown in the a utumn for early spring blossoms or can be sown early in the year for good flowers later in the spring. The plants must be transplanted twice in order to get the largest flowers; once from the seed box to a chosen bed, and again to the open garden. This is important for large size Pansies; use manure liberally. The bossoms are usually larger in the spring and again in the fall, and while they bloom freely all summer, the blossoms are small during the hot months.

Azure Blue. Golden Queen, Pure Yellow,

Dark Purple, Lord Beaconsfield, Emperor William. Dark Blue, Yellow with Black Eye. Snow White, King of the Black, Black, Giant Mixed, Fine mixed, 10c per pkg.

\section{PETUNIAS}

No bedding plants make a more pleasing display than Petunias.

First, be sure that the soil is well pulverized then sow the seeds on the surface, pressing them into the soil by using a small smooth board and cover very lightly with sand or fine soil. Seed sown in a hotbed or the house early in the spring will produce flowering plants in June.

DOUBLE MIXED ................. Pkt., 25e

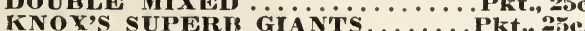

ELK'S PRIDF, DARK PURPLE... Pkt., 25c.

ROSY MOR V PINK

ROSY,MORN, PINK. $\ldots \ldots \ldots \ldots \ldots \ldots$ Pkt., 10c

BALCONY CRIMSON $\ldots \ldots \ldots \ldots \ldots$ Pkg., 10c
SINGLE MIXEU. $\ldots \ldots \ldots \ldots \ldots$ Pkt., 10e

\section{RUDBECKIA-(Golden Glow)}

Bicolor Superba - These hardy annuals are of easy culture and produce an abundance of flowers. The flowers have a cone in the center surrounded by yellow and brown petals. These bright flowers are borne gracefully on long stems, and are especially recommended for stems, and are

\section{RANUNCULUS}

Buttercup - Well-known double buttercup effective either as a cut flower or grouped in the hardy borders. Mixed colors. Pkg., 10e.

\section{ROMNEYA}

Coulteri (California Tree Poppy) $5 \mathrm{ft}$. An exceedingly beautiful, sub-shrubby, perennial with glaucous, pinnatified leaves, woody stems and large, satiny, white fragrant, Poppy-like

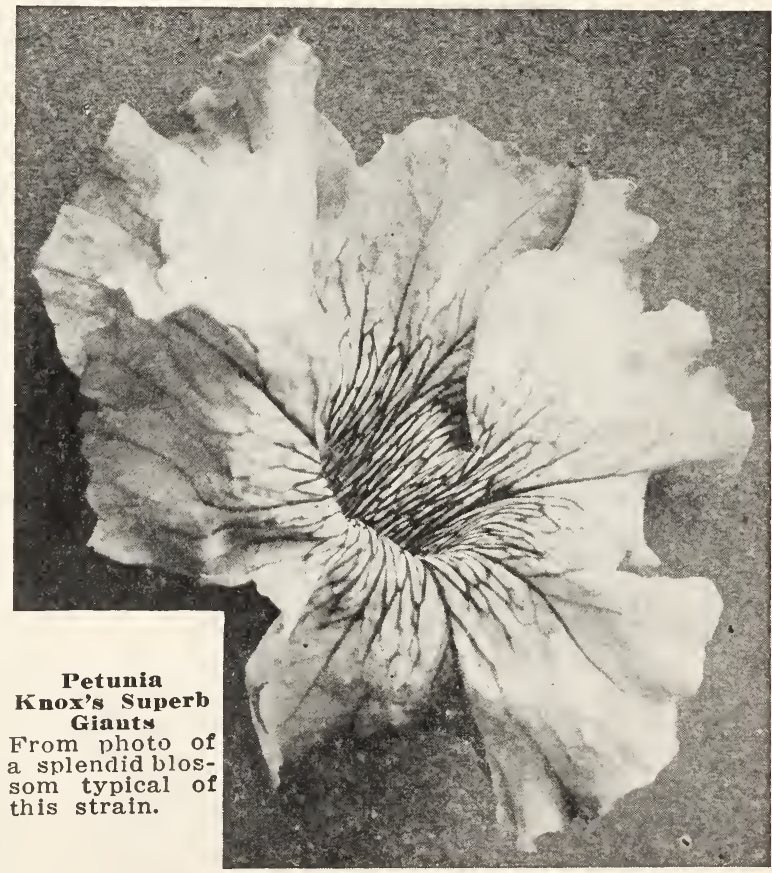
and large, satiny, 


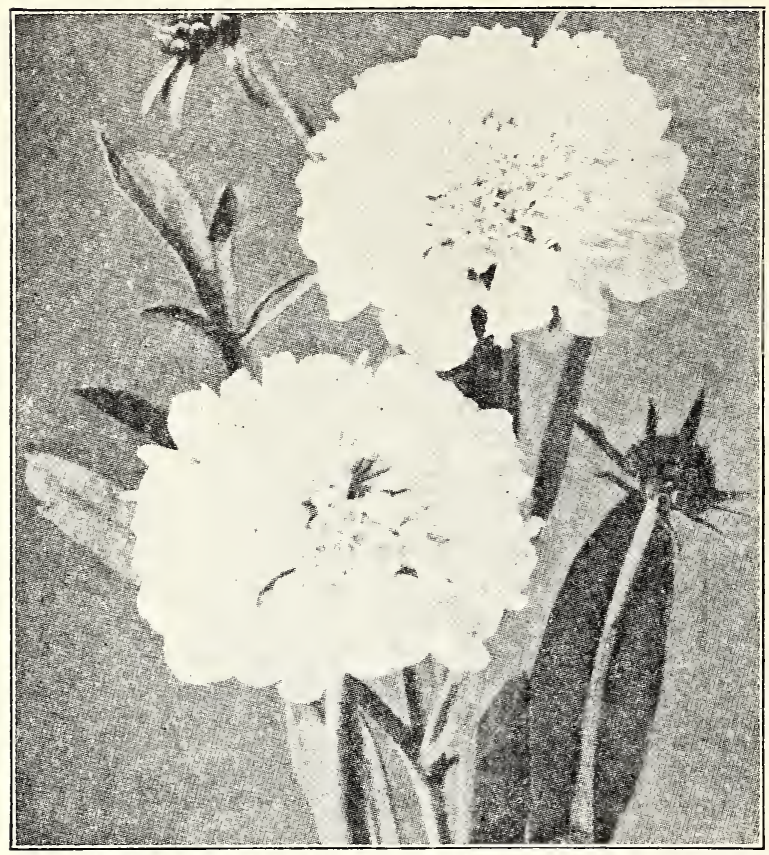

SCABIOSA-(or Mourning Bride)

A new, double, large-flowered type descended from the "Sweet Scabious" or "Mourning Bride" of old gardens, but are much improved in size, colors and doubleness. They are very free bloomers; very effective for garden decorations and valuable for bouquets, vases, etc. Annuals, $1 \frac{1 / 2}{2}$ to 2 feet $h i g h$. Mixed colors. Pkt., 10c.

Caucasica, Giant Hybrids (Isaac House Strain) Plants vigorous with larger and longer stems and larger and heavier petals, which are ruffled and slightly frilled on the edges. Perennial. Pkg., 25c.

\section{SENSITIVE PLANT}

Pudica-Curious half hardy annuals with pinkish white flowers; the leaves close or droop when touched. Sow from February to May in a box and transplant when well started. Pkt.. 10c.

\section{SILENE (Catchfly)}

Pendula Compacta-Bright double rose colored flowers produced in great abundance on dwarf compact plants. Very excellent for borders, masses and recommended for carpet bedding on bulb beds. Pkt., 10c.

\section{SALIPGLOSSIS}

These annuals are considered by many to be among the most satisfactory. They start easily from seed and very soon commence to produce their showy rich, dark-colored, bell-shaped flowers in great profusion, and continue in bloom until cut down by frost. Fine Mixed, Pkt., 10c.

\section{SAPONARIA (Bouncing Bet)}

Vaccaria-A pretty and useful annual variety, bearing an abundance of satiny pink flowers somewhat like an enlarged Gypsophila; fine for cutting; 2 feet tall. Sow in the open at intervals for a 2 feet tall. Sow in the open
succession of bloom. Pkt. 10c.

\section{SOLIDAGO (Golden Rod)}

3-5 feet. August-November. Gracefully arched sprays of golden yellow flowers. Seeds, pkt., 10c.

\section{SCHIZANTHUS-(Butterfly Flower)}

The sight of a few well-grown plants would induce anyone to grow them. They are simply elegant for decorative uses in pots or for cutting. Hybrida grandiflora compacta. These are large flowered with wonderfully beautiful color combinations in the same flower; 15 inches high. Pkt., 10c.

\section{SOLANUM CAPSICASTRUM}

For house or garden culture. The flowers are followed by small, brightly colored fruit or berries, which almost completely cover the plant. Pkt., 10c.

\section{SALVIA-(Flowering Sage)}

Half hardy perrenials, blooming the first year from seed, which should be sown as early as possible either indoors or in a hot-bed, and the young plants transferred to their flowering quarters when the weather has become settled and warm.

SPLENDENS-One of the finest of the Scarlet Sages, growing in a compact bush about 2 feet high by 2 feet in diameter. Its erect spikes of flowers of brilliant scarlet stand clear above the dark green foliage and completely cover the plant. A most gorgeous plant. Pkt., 10c.

Blue Patens-A hardy perennial. Pkg., 10c.

\section{STATICE LATIFOLIA}

(Sea Lavender) - These useful plants bear pur plish blue everlasting flowers that last a long time after cutting, and are of very easy culture. Hardy perennial. Two feet. Pkt., 10c.

\section{SMILAX}

A graceful greenhouse climber for table decorations, bouquets. etc. Pkt., 10c.

\section{SWEET WILLIAM}

Beautiful,, fragrant and easily grown, it is worthy of a place in every garden. The best varieties of Sweet William are of exceedingly beautiful colors, and the large fragrant flowers are borne in trusses of great size. They make a splendid show in the garden or hardy border and last well as cut flowers. Seed may be sown at any time from spring to mid-summer. Blooms during June and July. Perfectly hardy. Pkt., 10c.

SINGLE MIXED COLORS............Pkt., 10c

DOUBLE MIXED COLORS............Pkt., 10c

\section{HINTS FOR FLOWER GARDENS}

Many failures occur in the sowing of the very small seeded varieties of Flower Seeds as the result of covering too deeply, washing out by too heavy waterings or omitting to water in time, in which case they dry off, or shrivel up. Sow the Seeds in shallow seed pans, 2 or 3 inches in depth, first filling to within half inch of the rim with finely sifted soil, which press down firm and level; then scattering the Seeds evenly over the surface and covering with soil to three to four times the depth of the seed; the very fine seed should only be pressed down with a board. After sowing cover with a sheet of glass or a wetted sheet of paper until seedlings come through the ground after which remove the glass at least enough to admit fresh air or your seedlings will damp or rot off. As soon as they can be handled, transplant into similar boxes 1 to 2 inches apart, and when large enough put in the position where they are wanted to flower. Sweet Alyssum, Asters Nasturtiums, Migonette, Marigolds, and all hardy annuals, may be sown where they are intended to flower, not too soon, as seeds are intended to flower, not too soon, as seeds sown in a nice, warm seed bed will, with good weather, surpass those sown weeks before, as the
latter usually become stunted through weather set-backs. Thin out where they come up too thickly. Hardy perennials may be sown from January to October. Early sowings should be made indoors in shallow pans or boxes, as described above, or then can be sown outdoors from May to August and transplanted in early autumn. 


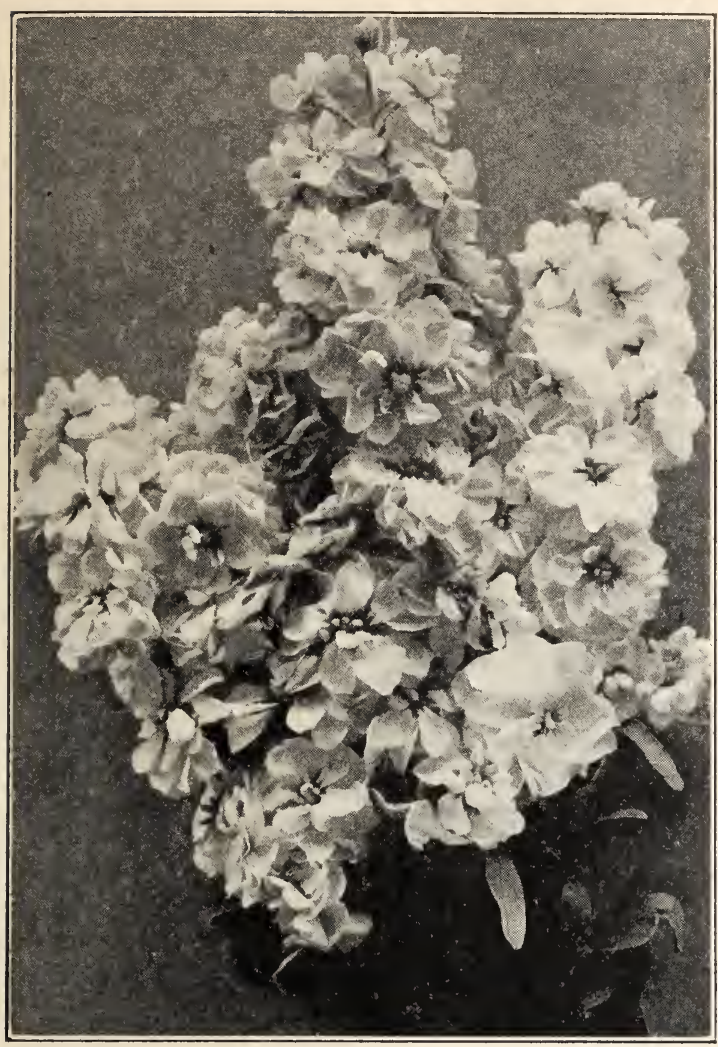

Early Branching Mammoth Nice Stocks VINCA

Rosea (Madagascar Periwinkle)-An attractive and ornamental plant. Very good for bedding and borders. It is free blooming and makes a fine cut flower, all the buds opening in water. It also makes a fine pot plant. Seed may be sown early in Spring in seed boxes or in the open ground after danger of frost is over. Flowers are rose, pink and white. Pkt. 10c.

\section{THUNBERGIA-Black-Eyed Susan}

Beautiful rapid growing annual climber. Prefers a sunny position. All colors mixed. Pkt., 10c.

\section{TRITOMA NEW HYBRIDS}

RED-HOT POKER PLANT These bloom readily from seed the first year. Quite a variation in colors-orange through orange-scarlets to an intense flame color. Height 18 inches. Hardy perennial. Pkt. 15e.

\section{VIOLETS-(Viola odorata)}

Beautiful for clumps, or edgings, forming a compact mass of foliage, with a profusion of purple, mauve-colored and violet blossoms. The seed should be sown early in cold frame, and the young plants removed to the border where they are to bloom.

Single Swcet-Scented-Blue-Pkt., 10c.

VALERIANA (Garden Heliotrope)

Rubra Mixed-A much prized showy hardy perennial. It bears dense clusters of small heliotrope-scented flowers of red or white. Blooms continuously and is easily raised from seed. Pkt., 10c.

\section{VISCARIA}

Mixed. $1 \mathrm{ft}$. Very showy and effective garden annual, producing large single flowers in red or white. Very bright and effective for beds and useful for cutting. Pkt., 10c.

\section{IMPROVED STRAIN OF DOUBLE FLOWERING STOCKS}

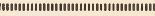

\section{GIANT WINTER STOCKS}

This wonderful new strain of Stocks is of branching habit, making it possible to break long branches of flowers from the main stalk without injuring or destroying the beauty of the plant. The flowers are large and many of them on a stem. The sweet perfume of the Stocks make them most desirable for garden or for vases.

Purple, Bright Red, Golden Yellow, Lavender, Lilac Rose White-pure white Azure Blue, Rose -Crimson King, Pkt. 10c. Mixed-all colors, Pkt. 10e.

\section{STOCKS, DOUBLE TEN WEEKS (Gilli Flower)}

These popular flowers are easily grown, and are so highly fragrant and of such beauty that they deserve a place in every garden. They are great improvements over the Gilli flowers of the olden times, being much larger and more densely double, and of a greater variety of colors.

Azure Blue, Red, Rose, Mixed Colors, Pkt., 10c.

\section{MAMMOTH VERBENA}

Free flowering, half hardy perennial of low spreading growth, usually treated as an annual. They make fine beds and edgings around the home. The trusses and individual flowers of our Mammoth Verbenas are of the largest size, of brilliant colors, free-blooming and are vigorous growers. Sow in early spring in boxes or in open ground after danger of frost is past. Transplant when 3 or 4 leaves are formed or thin out to 2 feet apart each way in a sunny location with good soil. Plants grow rapidly to a foot high and spread to 2 feet across the top. About a dozen single flowers form n each cluster or truss and colors and stripes range from white to deep purple and red.

Giant White-Pkt., 10c Giant Purple-Pkt., 10c. Giant Blue-Pkt., 10c. Giant Scarlet-Pkt., 10c. Giant PinkPkt., 10c. Vammoth Mixed-Pkt. 10c. Golden Queen, Pkt.. 15c.

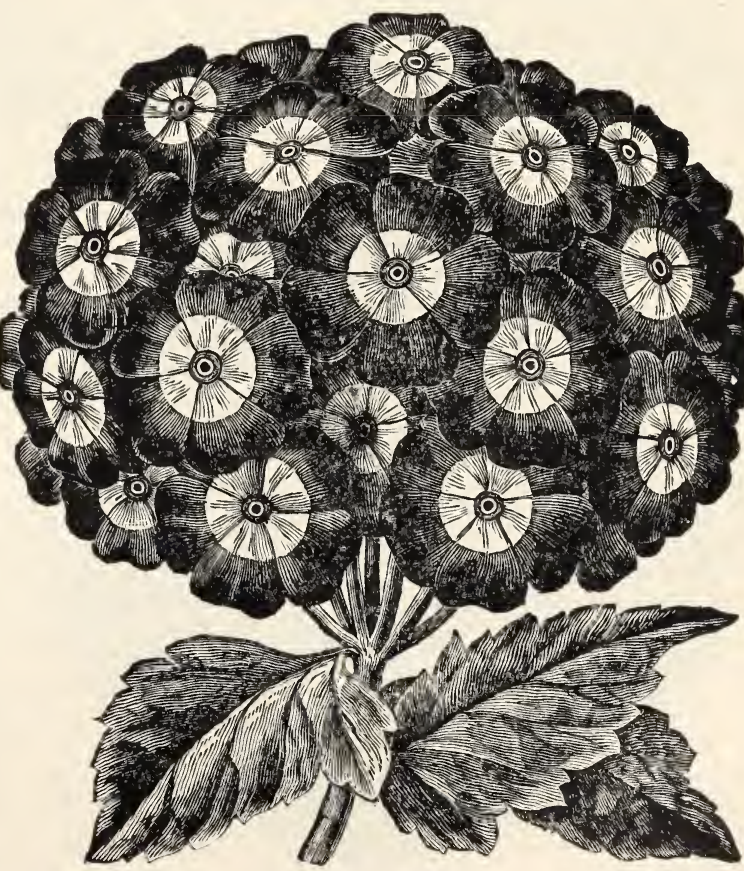

Giant Verbena 


\section{ZINNIA, GIANT FLOWERED MIXED}

This is an improved strain of the old and popular Zinnia, producing double flowers of great size, often three to four inches in diameter and in colors cover a wide range. The plants grow about fifteen inches high and the double flowers are produced in great abundance on short stems.

Crimson, deep flesh, golden yellow, orange, purple, white, mixed colors................. 10e

\section{ZINNIA, GIANT PICOTEE}

A remarkable new and different class with beautiful double flowers in orange, flesh, lemon, pink and cerise, each petal being distinctly tipped with various shades of dark, resembling the Picotee Carnations. Pkt., 10e

\section{ZINNIA, CRESTED QUILLED}

The petals of this type are peculiarly quilled. Varieties of rose and lilac, which when the petals twist, reflect pleasing autumn colors. Pkt., 10c.

\section{ZINNIA, NEW DAHLIA FLOWERED}

The plants are very sturdy and produce many flowers with stout stems. The flowers in full bloom often measure four inches in depth and six to eight inches in diameter.

The flowers differ from other Zinnias in the way the petals turn in toward the center which gives each flower a deep instead of flat appearance.

ORIOLE-Immense flowers of orange and gold. Very fine. Pkt. 15e.

EXQUISITE-One of the most pleasing shades. Color a light rose with deeper rose center. Pkt. 15e.

GOLDEN STATE-Yellow in bud, turning to a rich orange when in full bloom. Pkt. 15e.

METEOR-Bright crimson. The largest of the dahliaflowered type. Pkt., 15e.

CANARY BIRD-A delicate shade of primrose. Does not burn in the sun. Pkt. 15e.

DREAM-Deep lavender purple, a very beautiful shade. Pkt. 15e.

POLAR BEAR-A beautiful pure white flower of the form of a Dahlia. Pkt., 15e.

SPECIAL DAHLIA FLOWERED MIXTURE-This mix ture contains all of the Zinnia novelties and is a most wonderful collection. It will make an excellent garden show and produce fine flowers for cutting. Pkt. 15c.

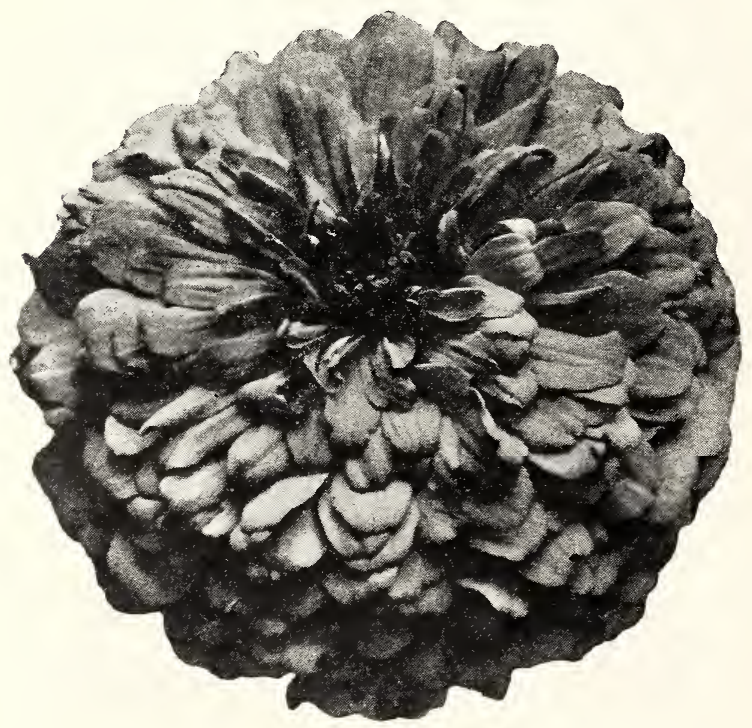

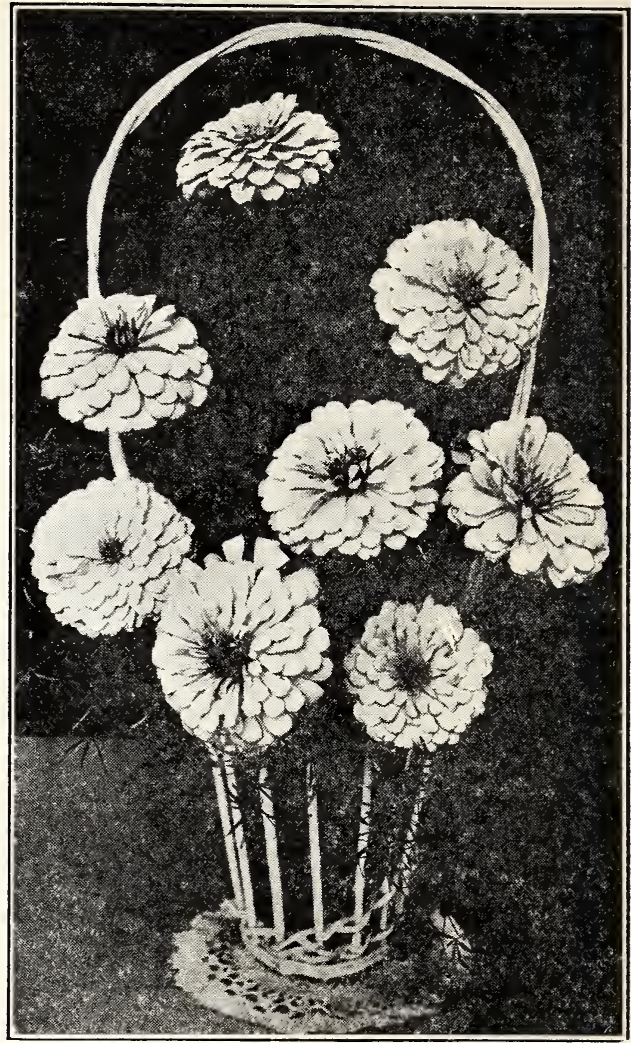

Double Giant Zinnias

\section{CALIFORNIA GIANTS}

The great advantage of this type is that the verv large flowers are of enormous size and flat getting away from the conical type of the Giants and eliminating the stiffness that has been so objectionable in Zinnias.

Cerise rose, light rose, lemon orange, soft pink, burnt orange, white bright rose, scarlet, mixed colors. Pkt., 10c.

\section{LILLIPUT OR POMPOM}

The compact bushes orow two feet high and are profusely covered by dainty double flowers on long stems. Mixed colors. Pkg., 10e.

WILD FLOWER GARDEN MIXTURE

These mixed flower seeds embrace more than a hundred varieties of such easy growing and pretty flowers as are suitable for forming a wild flower garden. They are very useful for woodland walks, roadsides, alongside of fences and on untidy bare spots which, if properly cared for and kept from weeds, can bloom during the summer. Pkt., 10c.

\section{WALLFLOWER}

(Cheiranthus Cheiri)

Produces spikes of beautiful, exceedingly fragrant flowers. Should be planted extensively all over the country. Blooms in May. Half hardy perennial. Pkt., 10e; double mixed colors. Pkt., 10e.

\section{WISTARIA}

PURPLE-Pendant cluster of purple flowers. Does not bloom until second year. Grows about 40 feet high. A hardy vine. Pkt., 15e.

\section{XERANTHEMUM}

A bright and pretty "Everlasting" with silvery foilage and silky flowers in rose, white and purple, which are not only. showy in the garden but very useful as dried flowers in Winter bouquets. Grows 2 to 3 feet high, can be sown in the open in Spring. Pkt. 10c. 


\section{Extra Choice Sweet Peas --- Spencer Varieties in All Shades---Plant Now for Early Spring Blooms \\ ALL SPENCER VARIETIES}

Sweet peas command the attention and admiration of every lover of flowers. They are so easy to grow, and produce such wonderful effects no home should be without them. Plant them along the fence, against the house or garage or string them up on wires or netting in the center of the yard. A southeast exposure is best but they will bloom most anywhere if they get part sunshine.

Plant them now and they will grow during the winter and develop a good strong root system and naturally produce a much larger and more beautiful flower. After spading break up any lumps and stamp the soil down very firm. Sweet Peas desire a firm seed bed to produce sturdy growth and long stems. Plant the seeds about one inch deep and six inches apart. Most people plant them too close together. After planting soak the ground good and as the ground dries keep the top worked up so that it will not crust or bake. When the plants are about three inches high it is time to provide some means of support. Stakes with strong string supports are fairly good but wire mesh is much better. Keep pruning out the lateral branches that have a tendency to cover one another as crowded plants never produce fine flowers. As fast as the sweet peas bloom cut (do not pull) them off as withered or dry blossoms spoil their looks and will cause them to go to seed too soon.

The sweet pea seeds we offer are grown by the best growers in the world and we can safely and conscientiously say that there are none better. A great deal of time and money is spent bringing out new and better varieties and improving the older sorts.

We submit the following list as the cream of varieties and feel sure that they will give entire satisfaction:

\section{NEW FLOWERING SWEET PEAS}

\section{GOOD CHEER-The flowers are} huge when well grown and are a lovely shade of deep Begonia Rose, both standard and wings being alike in color. The color does not fade in the sun and under artificial light is magnificent. Pgk., 25e.

CELEBRITY - The color is uniform in standard and wings, and bright rather than dark. Exhibitors who shade their flowers or amateurs who are prepared to shade will find "Celebrity" a marvelous orange color. Pkg., 25e.

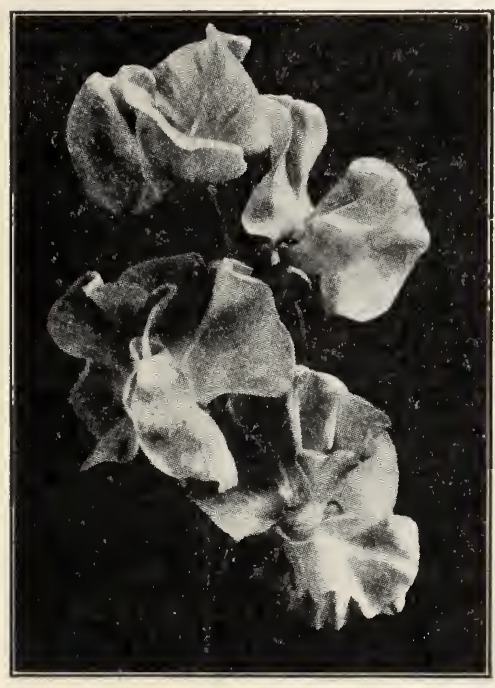

\section{CONQUEROR - A magnificent} large clear glowing cherry cerise. The standard and wings are alike in brightness of color. The vivid color suggests a brilliant scarlet red shade. The color is quite distinct from all other varieties. The vines are vigorous and the flowers borne on fine strong stems. The color improves under brilliant sunshine rather than fades and under artificial lights is very vivid. Pkg., 25c.

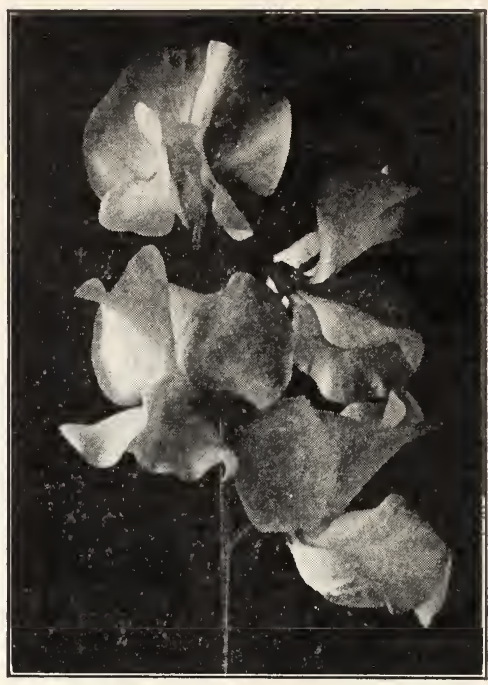

EOSINE-This fine novelty is another result of our crosses made for long stems and vigor of growth. According to the chart, the color is a beautiful tone of Eosine Pink with a soft flushing of salmon Pkg., 25e.

\section{SPRING FLOWERING}

\section{pkt. oz. $1 / 4$ lo.}

All $\mathbf{B} \mathbf{r}$ i h $t$, scarlet,

Osta Ohn, pinkist lavender ................

A us i n Frederick,

pure lavender ......10e 30e $\$ 1.00$

Countess $\mathbf{s}$ e n e r,

pink ........ 10e 30e \$1.00

Constance $H$ inton,

giant white, black

seed .............. 30e $\$ 1.00$

Crimson King, rich

oxblood crimson 10e 30e $\$ 1.00$

Del Monte, rich sal-

mon cerise pink...10e 30e $\$ 1.00$

efian e e, o r a $\mathrm{g}$

scarlet

lorence Nightingale,

bluish lavender pure

pink ............10e 30c $\$ 1.00$

Idyl, salmon pink....10 40e $\$ 1.35$

Illuminator, b $r$ ig $\mathrm{h}$ t

salmon cerise ....10e 30e $\$ 1.00$

King Edward, pure
red ............. 10e 30e $\$ 1.00$

Majestic Cream, large

deep cream ........10e 30c \$1.00

Mary Pickford, cream

pink suffused with

salmon .............10e 30e \$1.00

Miss California, sal-

mon pink .........10e 30e \$1.00
Irs. C ut h b e r tson, standard rose pink, wings white.......10e 30e \$1.00 Irs. Tom Jones, deep amethyst blue .....10e 30c \$1.00 Othello, deep maroon. 10e 30e $\$ 1.00$ President, brilliant or

ange ............... deepest orange...10e 30c $\$ 1.00$ Pinkie, rose pink....10c 30c $\$ 1.00$ Reflection, clear blue 15 e $75 \mathrm{c} \$ 3.75$ Ripples, $\mathrm{c} h$ a $\mathrm{r} \mathrm{m}$ i $\mathrm{n} \mathrm{g}$

flushed rose pink.. 15e \$1 \$3.75 Royal Purple, $r$ i $c$ purple ............ 10e 30e \$1.00 Royal Scott, brilliant scarlet ............10e 30e $\$ 1.00$ Tangerine, salmon orange ........... arrior, giant ma- 10 s0e $\$ 1.00$ Wedgewood, $\mathrm{b}$ $\mathrm{i} \ddot{\mathrm{g}} \mathrm{h}$ t blue ..............10e 30e \$1.00 Winnie Morse, cream ground lightly flushed soft rose

pink ...........10e 40e \$1.35

Youth, white edged

with a delicate soft

rose pink ..........10e 30e $\$ 1.00$ uuperb $S$ p e n e r Mixed ............. 10e 25e 75 e

FOR BETTER SWEET PEAS

If you wish larger flowers, longer and stronger stems, hardier vines, better colors and more flowers inoculate your sweet pea seeds with Farmogerm. It is easy to apply, just mix with the seed before you plant.

The bacteria are in a gelatine and furnish nitrogen to the plant increasing the vigor of the sweet peas. Order a box today. Farmogerm, garden size, Price 25c. 


\section{AIDS IN SELECTING FLOWER S EED FOR SPECIAL PURPOSES \\ BACKGROUNDS AND BORDERS}

Amaranthus Large, Showy Annuals

Colosia plumosa Marigold, Tall Salvia

Cosmos $\quad$ Poppy, Tall Sunflower

Dwarfer Sorts

Alyssum, hardy Godetla

Candytuft, hardy Dianthus

Carnation Myosotis

Pinks, hardy

Daisy, Double Pansy

EDGING WAIKS, ETC.

Ageratum

Lobelia compacta Sweet Pea,

Alyssum

Asters, Dwarf

Dusty Mille

(Centaurea) Pyrethrum

Marigold, Dware Cupid.

Myosotis

Phlox, Dwarf Nasturtium

Pinks, Chinese Zinnia, Dwarf

Amaranthus

UNUSUAL F

Centaurea Marvel of Peru

Canna

Acroclinium

Antirrhinum

Aquilegia

Aster

Calendula

Calliopsis

Centaurea

Campanula

Carnation

Chrysanth

Coreopsis

Dahlia

Centaurea
gynnocarp
Coleus CUTTING

Delphinium

Dianthus

Eschscholtzia

Gaillardia

Helianth us

Larkspur

Marigold

Matricaria

Mignonette

Myosotis

Nasturtium

Pansy aureum

Poppy

Pyrethrum

Scahiosa

Schibanthus

Stock

Sweet Pea

Sweet William

Sweet Sultan

Verbena

Wallflower

Zinnia

DRoOPING PLANTS FOR VASES. BASKETS, VERANDA BOXES, E'TC.

Alyssum

VERANDA

Petunia
Nasturtium

PLANTS SUITABLE FOR POTS THAT MAY BE

Ageratum

Antirrhinum,

Dwarf

Asters, Dware

Begonias

Carnation

Alyssum

Ageratum

Antirrhinum

Aster

Balsam

Calendula

Calliopsis

Candytuft

Carnation

Celosia

Ricinus

Antirrhinu

Aquilegia

Beflis

tuberosa I'igitalis

Canterbury Bells Matricaria

CLIMBING VINES, ANNUAI

Ralloon Vine Humulus or
Scarlet Runner

Bean Ipomoea, all Morning Glory

Cypress Vine kinds Nasturtium, Tall

Gourds, Orna- Momordica or Sweet Peas inental

CLIMBING VINES, PER ENNIAL

Australian Pea Cobaea scandens Lathyrus

$\begin{array}{lll}\text { Vine } & \text { Heliotrope } & \text { latifolius } \\ \text { Clematis } & \text { Kudzu Vine } & \text { Smilax }\end{array}$

\section{INSECTICIDES AND FUNGICIDES}

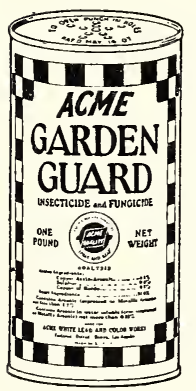

ACYE GARDEN GUARD

No sprayers, no water no mix-

ing. Dust on plants from sifter top carton or through burlap sack. Acme Garden Guard is the strongest garden insecticide of its type on the market-yet safe to use. Ideal for the housewife to use.

$$
\text { For Use On }
$$

Cabbage, cox Use On plants, melon vines, currant and gooseberry bushes and other vegetables, flowers and shubs of many kinds.

The Bordeaux Mixture in Garden Guard acts, in a measure, as a fungicide. 1-1b., Sifter Carton,, 35e
5-16. Paper Bag....\$1.00

ACME 2-WAY SPRAY

An approved balanced Insecticide and Fungicide containing $14 \%$ Arsenate of Lead and $83 \%$ Bordeaux Mixture-2 results with one spray.

Coutrols insects, combats blight, stimulates foliage.

Easy to apply-wet or dryFor dusting apply lightly, as it comes in the package.

In spraying apples, grapes, muskmelons, potatoes, squash and tomatoes, use $9 \frac{1}{2}$ level tablespoonfuls to 1 gallon of water.

1-1b., carton, 45e; 4 lb. carton

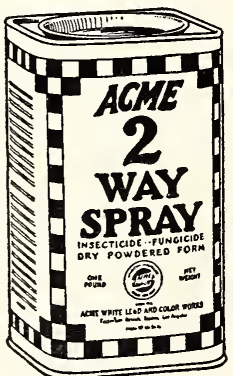
\$1.60.

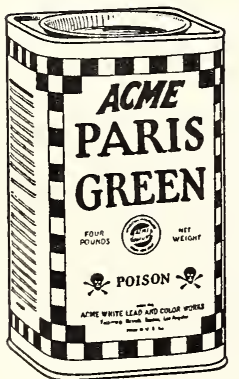

ACME PARIS GREEN

The deep, rich emerald color stamps Acme Paris Green as a standard of quality. Always uniform, fluffy and free running, it assures the user of maximum results. When used dry will not clog the dusting machinery.

For potato bugs, use from 1 to $3 / 4$ of a level tablespoonful to 1 gallon of water. Apply as a gallon of water. Apply as a Paris Green, 1 part flour, 5 parts lime. On tobacco, use as a dust alone or mixed with Arsenate of Lead.

1 1b., 55e; 5 lbs., \$2.00.

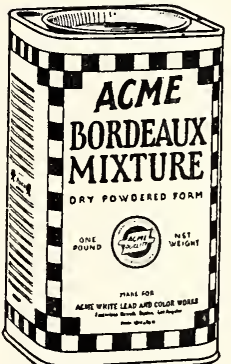

ACME HORDEAIX MIXTURF

Prevents large losses caused by blight rot, mildew, scab, an thracnose, and certain other fungous diseases, will stimulate plant growth and greatly increase the harvest. On apples, grapes, currants, gooseherries, strawberries, pecans, potatoes and tomatoes, use 8 level tablespoonfuls to 1 gallon of water. For spraying sour cherries, plums, celery, beans, oranges grapefruit and lemons, use level tablespoonfuls to 1 gallon of water.

1-1b. Carton, 35e; 4-Ib. paper bag, $80 \mathrm{c}$.

ICME ARSENATE OF LEAD It kills the bugs, sticks to the
leaves and does not burn or injure the foliage.

While these qualities make it the favorite spray for fruit trees, it also gives splendid results vegetables and tonaid

Arsenate of Lead is recommended to control leaf eating insects on apples, cherries, currants, goos eb e r ries, grapes, peaches, pears, plums, strawberries, pecans, asparagus, beans, cabbage, cauliflower, potatoes, tomatoes, and tobacco.

When dusting fruit, add 5 parts hydrated lime. Vegetables

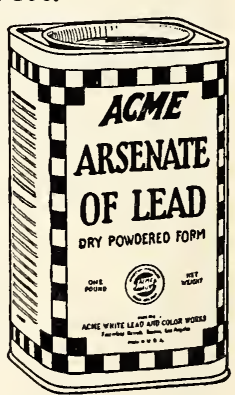
1-1b. carton, 45e; 4-1b. paper bag, $75 c$

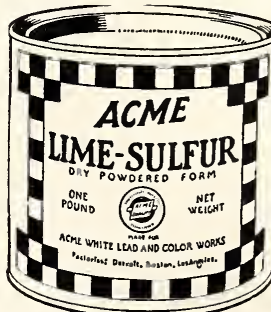

ACME LIME SULFUR Acme Lime Sulfur is a $33^{\circ}$ Baume Lime and sulphur solution, converted into dry powdered form, having all the effectiveness without the bother of handling.

For dormant spraying in the fall or early spring against Scale, Peach Blight, Leaf Curl and Twig Borer, use 9-11 tablespoonfuls to 1 gallon of water.

For $\approx u m$ m er spraying use from 2 is to 3 level tablespoonfuls to 1 gallon of water.

1-1b. can, 35c; 5-1b. can, \$1.25; 10-1b. can, \$2.25. 


\section{Orchard and Garden Supplies}

\section{TREE SEAL}

TREE SEAL meets with the approval of the University Farm at Davis, Calif., the Citrus Experiment Station at Riverside, Calif., and the Agricultural Extension Service.

Everyone who has used hot waxes will instantly appreciate TREE SEAL which is applied cold in any kind of weather except when raining or freezing.

TREE SEAL may be applied cold with a brush or paddle in any kind of weather except when raining or freezing, and dries in from 20 to 60 minutes, and when dry is unaffected by climatic changes. We suggest a second application of TREE SEAL on large grafts about one week after first application.

TREE SEAL, when applied to trees and shrubs, will prevent mouse and rabbit injury and should be used as a dressing when such injury has occurred.

Tree SEAL has been endorsed in the highest terms by the California State Agricultural Col lege, and it is by far the most efficient product of its kind on the market, as well as the most economical.

TREE SEAL may be obtained in the following size containers:

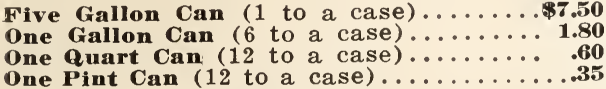

Postage extra.

\section{ANCHOR SULPHUR}

It has been proven and so recommended by the University of California that if you sulphur your grape vines and orchards six times they will not be affected by Mildew or Red Spider.

A hor Brand Velvet Flowers of Sulphur, packed in double sacks the fluffiest and purest sulphur that money can buy; the best for vineyards; the poses, leaving no ash. Per ib 10e; \$4.40 per sack of 100 lbs., f. o. b. Stockton.

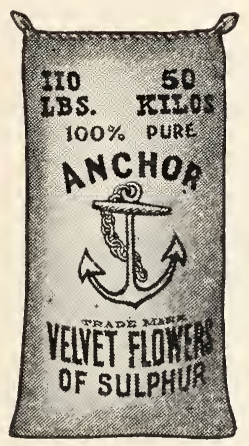

\section{TO INCREASE CROP YIELDS}

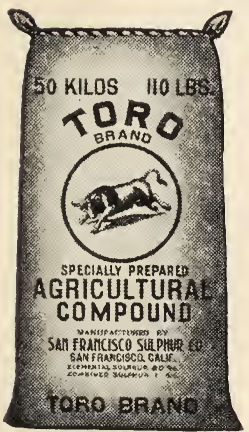

Experiments c o n d u c t e d during the past few years by noted soil chemists and practical cultivators have revealed that Sulphur:

I-Improves Alkali Soil. 2 -Promotes Nitrification. 3-Transforms Latent Potash and Phosphates into available Plant Food.

It renders the potash and phosphoric acid soluble in water. These minerals in solution, together with Sulphur in the form of sulphates, are eagerly absorbed by plants, with the result that crops are increased even four and five fold.

4-Inereases protein and feeding value.

5-Destroys the spores of Fungi and the larvae of injurious insects in the soil. Prevents Potato Seab, Wire Worms, Eel Worms, or Nematodes, Ete.

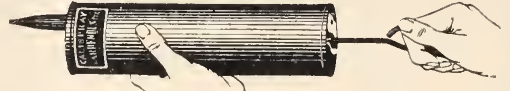

This is a medum-sized duster for use in the is very effective GARDEN DUSTER in applying Garden Dust in places that are difficult to reach with any other duster. If you have any dusting at all to do this little gun will please you. Each \$1.00, f. o. b. Stockton.

\section{GRAFTING WAX}

A Lion Brand preparation for healing wounds on trees, caused by pruning. Very excellent also for spreading around the graft in grafting propagation. Three sizes: Lb., 60e; 1/2 1b., 35e, and $1 / 4$ 1b., 20e.

\section{GARDEN TROWELS}

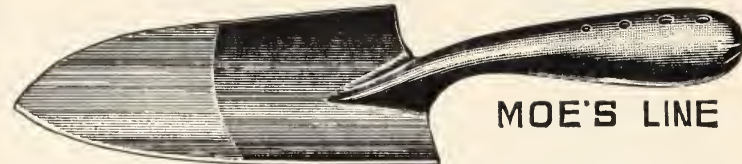

No. 80-Garden Trowel. One piece, pressed steel. Handsomely finished in black baked enamel. Length of blade 6 inches. Ground and polished points. Shipping weight 2 lbs. Each 25c.

\section{TRANSPLANTING TROWELS}

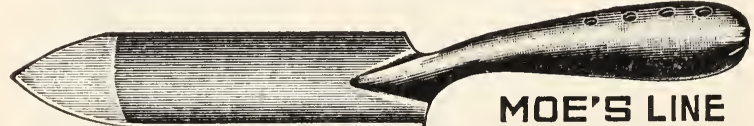

No. 81-Transplanting Trowel. One piece pressed steel. Handsomely finished in black and baked enamel. Length of blade 6 inches. Width $13 / 4$ inches. Ground and polished points. Shipping weight $2 \mathrm{lb}$. Each 25e.

\section{STEEL GARDEN WEEDERS}

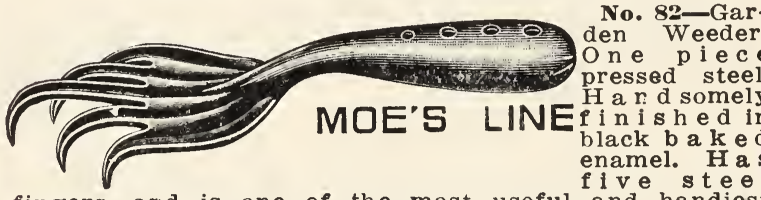
fingers and is one of the most useful and handiest garden tools made. Ground and polished points. Shipping weight 2 lbs. Each 25e.

\section{GALVANIZED GARDEN TROWEL}

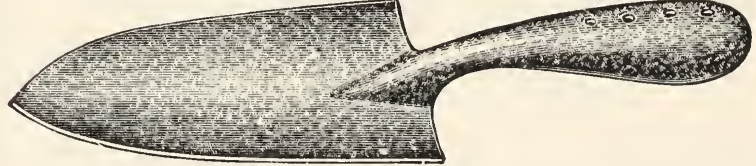

No. 85-Garden Trowel. Made of a single piece of heavy galvanized steel. Handle and blade all in one piece. No wood handles to break or come off. An excellent tool at a low price. Length of blade 6 inches. Each 10e.

\section{GARDEN HOSE}

This is the highest grade of garden hose, being made entirely from New Para Rubber, and will outlast cheap hose three times over. We guarantee it to stand a $300-1 b$. water pressure, and it will be as resilient in three or four years' time as when new, while cheap hose of that age will be hard and rotten. Every length of hose is fitted with the new water-tight couplings, without extra charge. (Hose is furnished couplings, without extra charge. (Hose is furnished refers to the internal diameter of the bore)

Prices-3/4-inch bore, per 25-ft. length \$2.50; per 50ft. length, \$5.00. 


\section{Orchard and Farm Supplies--continued}

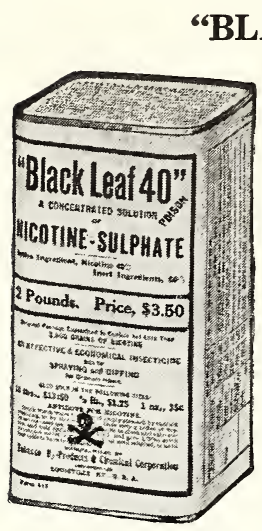

1 oz., 35c-Makes 6 gallons spray.

1/2 1b., \$1.25-Makes 40 to 120 gallons.

2 lbs., \$3.75-Makes 160 to 500 gallons.

10 lbs., \$11.85-Makes 800 to 2500 gallons.

\section{VOLCK}

The Scientific Orchard Insecticide

Volck is primarily a contact insecticide. It kills insects in various stages of their life cycle-egg, larval and adult. VOLCK possesses a wide margin of sofety to the plant and fruit. This quality of VOLCK makes it possible to spray at the time of the year when an insect pest is most easily killed. This wide margin of safety makes possible really effective pest control, even of the most resistent scale or Mealy ug. It also makes it possible for a also makes it possible for a grower to adjust his pest control program so as to control several pests at the same time, thereby lessening the number of necessary spray applications.-Price 1/2 pt. 40e, Qt. 80e, gal. \$2.15, f. o. b. Stockton.

\section{HOT KAPS}

A new irvention that is taking the market gardeners by storm. So constructed that the wind cannot blow these plant covers away, because the machine places dirt around the edges. They are already folded ready for use. One man can do the work of four. After setting, the field looks uniform, like a well kept garden. Price per 1.000 \$11.50. Less than 100 lots, 1e each. Write for prices in larger quantities.

\section{BLUE STONE-(Copper Sulphate)}

Blue Stone is extensively used as a dormant spray against Curl Leaf, Shot Hole Fungus, Brown Rot and any other fungus diseases.

To obtain a 5-5-50 mixture, five pounds of Blue Stone, five pounds of unslacked lime and fifty gallons of water should be mixed.

First dissolve the Blue Stone in a tank and slack the lime in another tank. Pour the contents of these two tanks into a third tank, being sure that you pour them both at once or they will not mix. Do not add the Blue Stone to the lime or the lime to the Blue Stone.

If a stronger solution is desired, 6,7 or 8 pounds of each material may be used.

Pricen. 1 th.. 10e: 10 lbs.. 85e: 50 lhs.. 84.00: 100 lbs., \$6.50; bbl., 400 lbs., 6 e per lb., f. o. b. Stockton.

LIME-For use in making Bordo A very high grade lime. Packed in steel barrels of 180 lbs. each, \$3.00 f. o. b. Stockton.

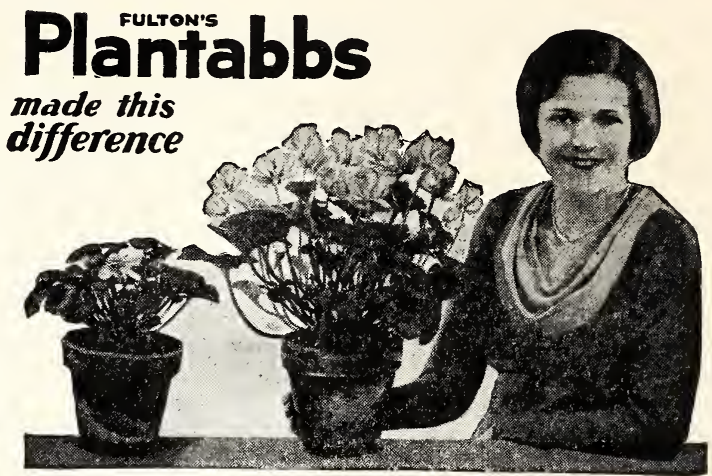

No waste, No Weeds, No Runoff, Uniform Feeding, Easy to Use, Immediate Fertilization, Economical, Guaranteed Analysis: Nitrogen 11\%; Phosphoric Acid 15\%; Potash $20 \%$, being the most concentrated plant food tablets on the market.

30 Tablets 25c; 75 Tablets 50c; 200

Tablets $\$ 1.00 ; 1000$ Tablets $\$ 3.50$.

\section{NOW YOU CAN GROW LAWNS}

- Gardens, Trees, Shrubs Successfully with

VIGOIRO . . . . the Complete Plant Food.

It contains all the plant food elements needed to produce early, vigorous growth and bring fruit, flowers, and foliage to full development.

Vigoro is inexpensive-only $10 \mathrm{c}$ to $20 \mathrm{c}$ for every 100 square feet $(10 \times 10)$. It is clean, odorless, and easy to apply. Full instructions with every bag.

\section{TABLE OF APPLICATIONS}

Use these quantities in spring and fall; one-half as much for summer applications. Allowance has been made for space occupied by house, walks, etc.
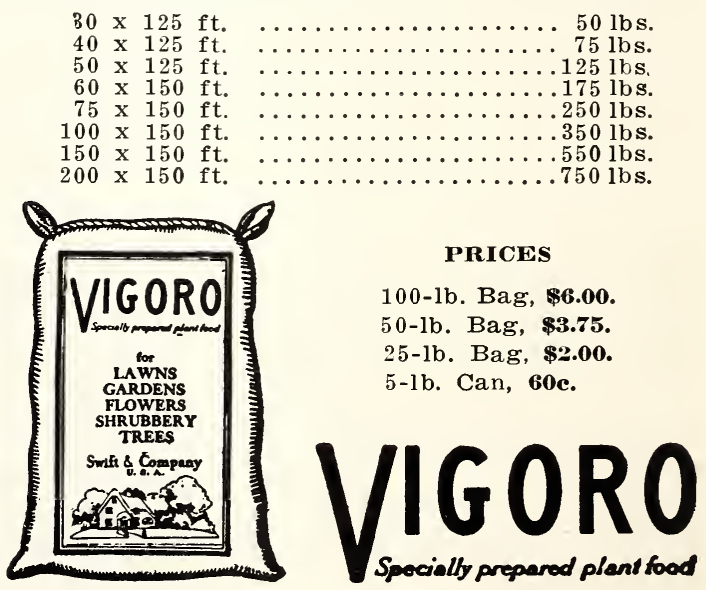

\section{FISH SOAP}

FISH OIL SOAP - For destroying lice and insects on plants and rose bushes, dissolve one pound in $1 / 2$ gallon of hot water, and add enough cold water to make five gallons of spray. 1 b. $25 c$. cold water to make five gallons of spray. 1 lb., 25e. other sprays. Price. 40 lb. can, \$6.50. 


\section{Feed and Poultry Supplies}

\section{SPIR-0-BANDS}

We have them in all colors and all sizes. Fast colors, keep their shape, light in weight and durable. Quickly removed or put on. Ten different colors. Red, Pink, Dark Blue, Light Blue, Black, Yellow, Green, White, Garnet and Cerese.

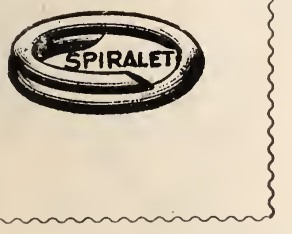

Kind

Baby Chick

Pigeons

Growing Chicks

Bantams

Leghorns

Large Leghorns

Rocks and Reds

Asiatic

Hen Turkey

Tom Turkey

\section{STAR CHICK FEEDER and FOUNTAIN}

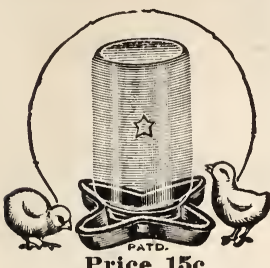

Price 15e

\section{MOE'S DRY MASH HOPPERS}

A Dry Mash Hopper of great merit, made of heavy galvanized iron. The curved bottom keeps the feed within easy reach of the birds. The wire grid and the wires running from the flange through the wire grid prevent the fowls from throwing out or wasting the feed. The sloping top prevents them from roosting on the hopper. When both covers are closed it

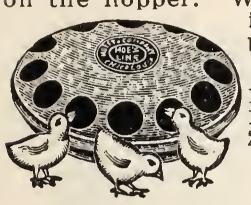
is rat.

Made in four sizes:

10 Qts., Ship. Wt., 5 ibs.. \$1.65 14 Qts., Ship. Wt., 7 lbs., \$2.20

MOE'S DOUBLE FEEDING TROUGH

\section{ROUND FEEDER}

No. 11-Diameter 6 in. with 8 holes. Price each 15e: per doz., \$1.80.

No. 12 -Diameter $81 / 4$ each 25e; per doz., \$3.00. in., with 12 holes. Price

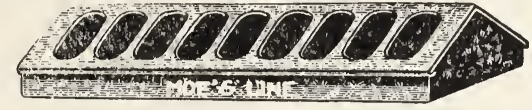

Made of best quality galvanized iron, accurately stamped with dies. No sharp or rough edges to injure the chicks. Sliding top. Easy to fill and clean. Made in three sizes:

No. 58, 12 in., each 45e; No. 59, 18 in. each 60e; No. 60.24 in.. each 70c.
COLONY HOUSE DRINIKING TROUGHS

This through is made of 28 gauge galvanized iron, round bottom straight ends, equipped with a foot and hanger. They are formed by machinery which accounts for the very low price. No. 9, length 36 in., width 4 in., depth $2 \frac{3}{4}$ in., wt. 25 lbs. Each $75 c$.

\section{THE RELIALE UTOMATIC FLOA VAVE}

This valve is the most efficient Automatic Water Float Valve ever offered to the Poultry world and priced so reasonably. It is constructed of brass and copper, which makes it rust proof, and will last indefinitely. Easy to install, requires no adjustments and will work under any water pressure, valve core can be renewed without removing valve from pipe line. Fach \$1.00.

\section{CARBOLA}

Disinfeets and Paints at the same timeand time.

$\mathrm{Carola}$ is two things in one-a paint and a disinfectant. It is not a whitewash or is not a white

Stays white and has no disagreeable odor. 1 lb., 35e; 10 lbs., $\$ 1.50 ; 50$ lbs., \$5.00.

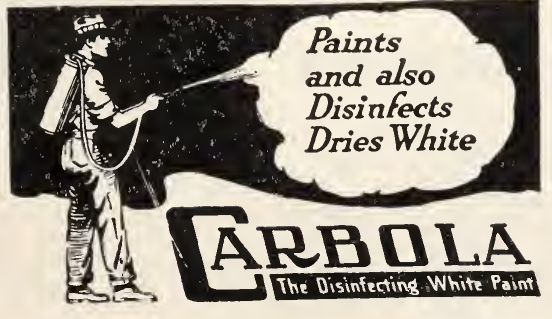

$\begin{array}{crr}00 \text { bands } & 500 \text { bands } & 1000 \text { bands } \\ \$ 0.40 & \$ 1.10 & \$ 2.00 \\ 0.45 & 1.25 & 2.25 \\ 0.50 & 1.50 & 2.75 \\ 0.55 & 1.60 & 3.00 \\ 0.60 & 1.70 & 3.15 \\ 0.70 & 2.00 & 3.75 \\ 0.80 & 2.10 & 4.00 \\ 0.90 & 3.00 & 5.50 \\ 1.00 & 4.00 & 7.50 \\ 1.10 & 5.00 & 9.75\end{array}$

5.00

\section{FOUNTAINS}

10

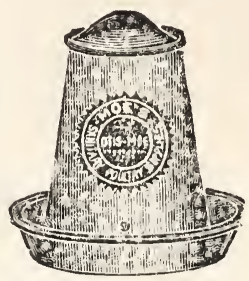

KRESO DIP No.1

IS. WORTH CROWING
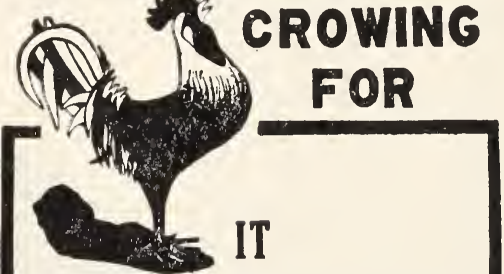

KEEPS POULTRY HEALTHY

\section{EXTERMINATES}

\section{LICE AND MITES}

and used freely as a disinfectant it proves a sanitary protection against the common poultry diseases.

\section{Use it on All Livestock}

\section{to}

Kill Insect Parasites and Help

Prevent Contay:ous Diseases.

Efficient-Easy to Use-Economical

Write for free descriptive booklets.

Kreso Dip No. 1 in Original Packages

Pts.. 50c; Qts., 75e; 1/2 gnl., 81.25; gal. \$2.00; s gai., \$9.00. Not prepaid. 


\section{Buckeye "Blue Flame" Brooder}

During the past five years we have kept our Experimental Department busy with a view of developing a coaloil (kerosene) colony brooder that would come up to our of pleasure to tell the poultry producers at large that we have perfected such a truly remarkable blue-flame brooder, that every brooder we sume will be sold under the same 30 days money-back always given with our ccalburning brooders.

No. $27 \mathrm{~A}-200$ Chicks. . . \$15.50

No. $80-350$ Chicks.... 17.00

No. $81-500$ Chicks.... 19.50

(f. o. b. Stockton)

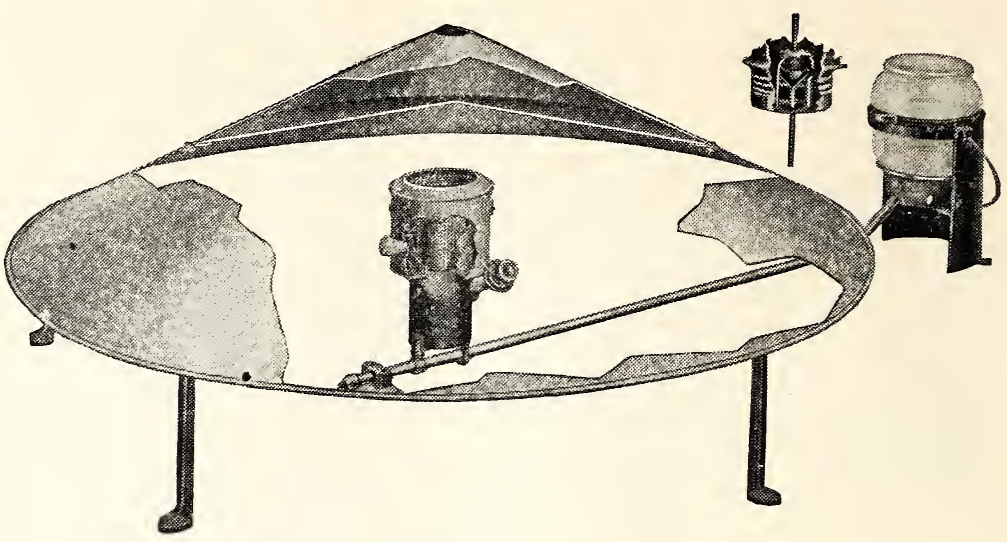

\section{The Buckeye Standard Colony Brooder}

Since January 1, 1915, 100,000 Standard Buckeye Brooders have been sold. This machine has such a wonderful record among poultry raisers that it is not necessary for us to go into detail describing it. It is a coal burner, burns either soft or hard coal; selfregulating; can be operated in any room in any temperature. It is the simplicity of the Standard and its reasonable price that makes it the most popular brooder on earth. The Standard is made in two sizes:

No. 118 - Capacity 500 chicks, weight 74 lbs. price \$21.00.

No. 119 - Capacity 1000 chicks, weight 94 lbs., price, \$26.00.

F. O. B. Stockton.
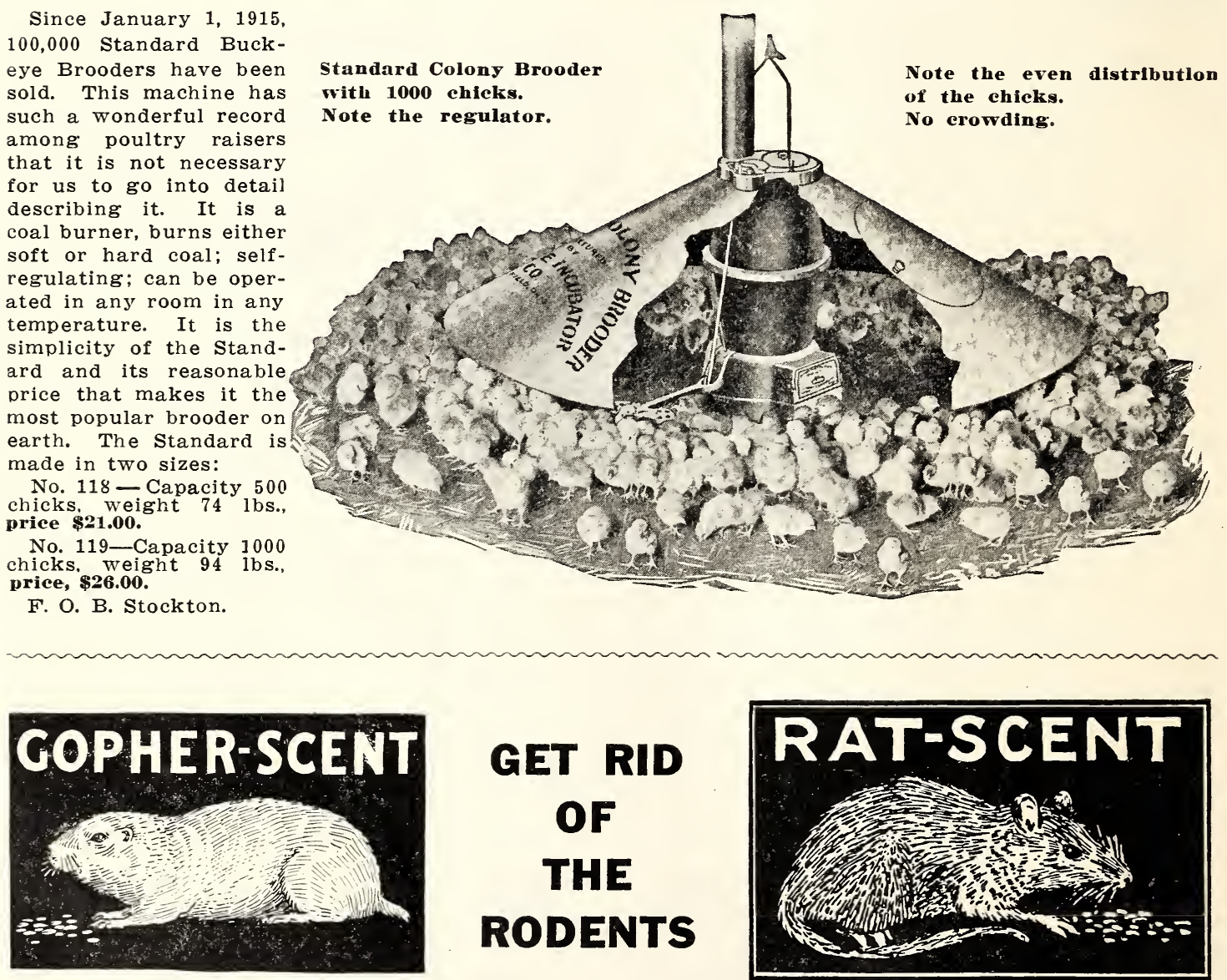

Gopher scent is the latest and most improved method of poisoning gophers and squirrels. The scent attracts the gopher and draws him to the bait. We have had some wonderful reports on Gopher Scent and feel that we cannot recommend it too highly. Small pkg., 35e. Cannot be mailed.
A specially prepared poisoned grain. The scent attracts rats and mice to the bait and the grain itself is agreeable to their taste. Place it in small piles around holes and places they frequent. It is very effective. Pkg., 35e| Cannot be mailed. 


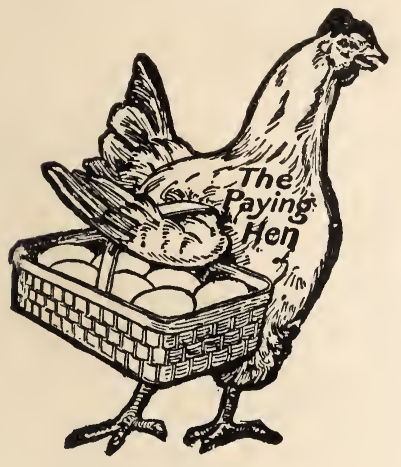

It also contains internal antiseptics that counteract disease; insures a healthy. singing poultry flock. Costs but a trifle-a penny's worth is enough for 30 hens per \$1.85. Not postpaid.

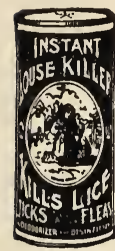

\section{INSTANT LOUSE KILLER}

DR. HESS'

PAN-A-MIIN

makes poultry healthy; makes hens lay a stimulant, but the dormant egg orrans, brings back the scratch and cackle; and compels each hen to put her share of eggs in the market basket.

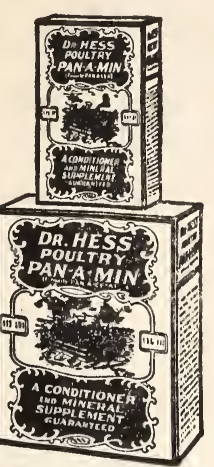

Kills lice on poultry, horses, cattle, sheep ticks: bugs on cucumber, squash and melon vines; cabbage worms; slugs on rose bushes, etc. Sold in sifting-top on rose bushes, etc. Sold in sifting-top cans-look for the
buying. $30 \mathrm{c}-60 \mathrm{c}$.

\section{DR. HESS FLY CHASER}

Drives flies away. One application lasts six hours. Prevents milk slump. Keeps cattle and horses contended during the fly season. Most humane idea of the age. Its use during summer months will insure good profits.

1 Gallon $\$ 1.75$

DR. HESS'S STOCK TONIC

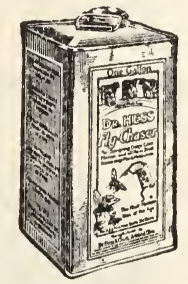

Small size...................75c

DR. HESS'S ROUP RFMEDY

4 oz. cans

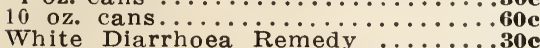

White Diarrhoea Remedy $\ldots . . . . .60$

\section{DR. HESS'S HEALING POWDER}

4 oz. cans $\ldots \ldots \ldots \ldots \ldots \ldots \ldots \ldots \ldots \ldots$
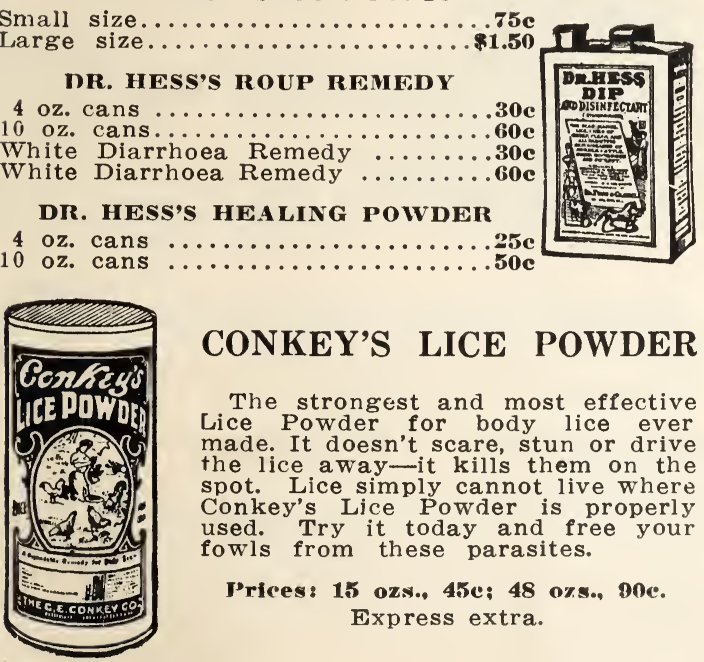

\section{CONKEY'S LICE POWDER}

The strongest and most effective Lice Powder for body lice ever made. It doesn't scare, stun or drive the lice away-it kills them on the spot. Lice simply cannot live where Conkey's Lice Powder is properly used. Try it today and free your fowls from these parasites.

J'rices: 15 ozs., 45e; 48 ozs., B0e. Express extra.

\section{CONKEY'S REMEDIES}

Conkey's Gape Remedy .................... 60e

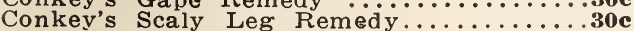

Conkey's Roup Remedy ..............

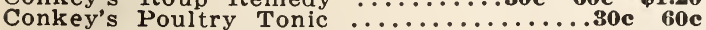
Conkey's Head Lice Ointment ......................... 60e

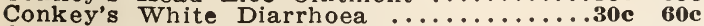
Conkey's Poultry Worm Remedy ................. 60e Conkey's Chicken Pox ...................... 60e
PRATT'S POULTRY REGULATOR

It builds up vitality, insures sound digestion, sharpens appetite and

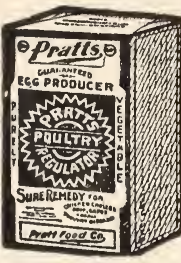
ts disease, thus putting birds in condition for heavy egg laying or winning blue ribbons. Pratts is the original Poultry Regulator of America and is in use by the most successful poultry raisers everywhere. When regularly used, hens lay throughout the year. It will prevent chicken cholera, gapes, roup. vent chicken cholera, gapes, roup, leg weakness and egg eating. It will greatly improve turkeys, geese, ducks, pigeons and guineas, insuring quick growth and keep them free from disease. Packages, 30e, 85e, \$1.25

\section{PRATT'S REMEDIES}

Pratt's Roup Remedy .................. 60c

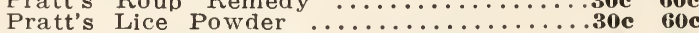
Pratt's White Diarrhoea Remedy ............... 60e Pratt's Chicken Cholera Remedy ..........30e 60 Pratt's Sore Head-Chicken Pox Remedy..30e 60c Pratt's Scaly Leg Remedy ..................

\section{LEE'S GIZZARD CAPSULES}

The GIZZARD CAPSULE is a triple combination medicine, containing Kamala for Tape Worms, Nico tine for Round Worms and Pyrethrum for Pin Worms. The medicine is enclosed and sealed in an air tight insoluble container which carries the medicine through the crop, through the stomach and in to the Gizzard. There it is ground up, like a grain of corn, releasing the medicine in full strength at the door of the intestines where it is poured in upon the worms With the insoluable GIZZARD CAP SULE there can be no diluting of medicine.

PRICES, CHICK SIZW

50 Capsule package

100 Capsule package

250 Capsule package

500 Capsule package

PRICES, A DULT SIZE

50 Capsule package

100 Capsule package

250 Capsule package

500 Capsule package

1000 Capsule package

Manufactured in These Sizes Only
$\$ \quad .50$

$\stackrel{.90}{.200}$

6.00

$\$ 1.00$

1.75

$\mathbf{7 . 0 0}$

$\mathbf{7 2 . 0 0}$

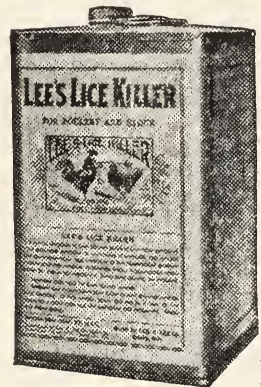

LEE'S LICE KILLER

Lee's Lice Killer has been for twenty years the poultryman's stand-by in keeping chickens stand lice, nites and scaly- leg. A liquid. simply plainted on the roosts.

Sizes 60e, 90e and $\$ 1.50$

GERMOZONE
Germozone is the
most popular med-
incine for poultry and for stock and the most generally effective. For roup, canker, chicken pox, sore head, skin disease, bowel trouble, 40e, t5e and $\$ 1.50$ GERMOZONE TABLETS

Germozone Tablets-This is the same as the liquid, only in a more convenient form. When dissolved in water they act the same way as the Germozone liquid.

In three sizes, 25e, 75e and $\$ 1.50$.

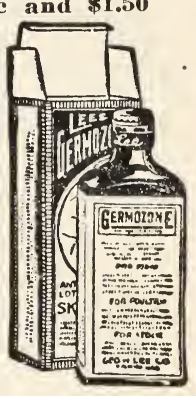

\section{LEE'S LOUSE POWDER}

Lee's Louse Powder is big value in both size and quality. 1 lb., pkg. for 30c; $21 / 2$ lbs. 60c. Round sprinkler top cartons. Very effective.

\section{BARNES' WORM EMULSION}

Is an invigorating, nourishing fluid. It increases the assimilating juices in the intestinal tract, will kill the worm, it will be digested and returned to the nourish- 


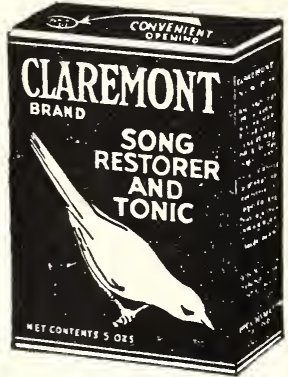

CLAREMONT SONG RESTORER AND TONIC

A preventative against diseases common to canaries and all seed eating birds. It is a vitalizing tonic, stimulant and rest or e r Also assists in flesh and bone building. A good feather producer, easily digestible, promoting health and robustness. Pkg., 25c.

\section{BIRD SUPPLIES}

\section{Special Mixed Bird Seed 15c per lb. postpaid}

\section{Write for Prices in Large Quantities}

Postage Must be Adde d to These Prices

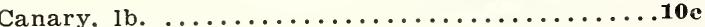

Hemp, th $\ldots \ldots \ldots \ldots \ldots \ldots$.

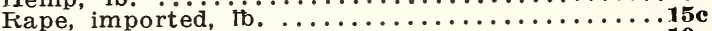

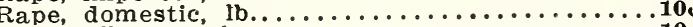

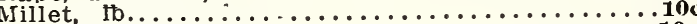

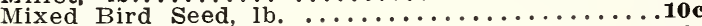

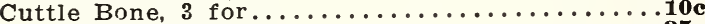

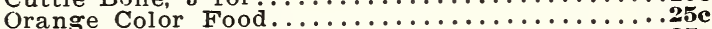

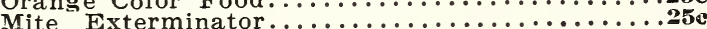

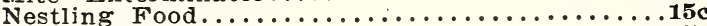

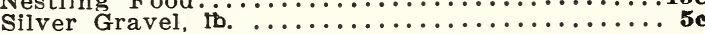

Cage Springs, single, each .............15c

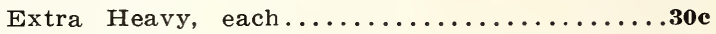

Feed and Water Cups, each...............15c

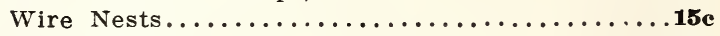

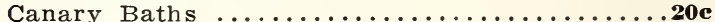

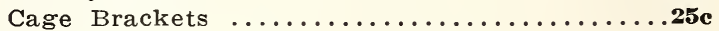

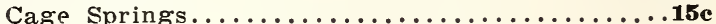

Hennings' Bird Tonic..................25e

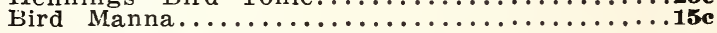

\section{Garden and Household Necessities}

SNAROL

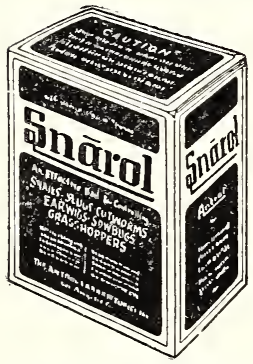

A Ready-to-Use Positive Comtrol for Hard Shelled Snnils. SNAROL is a boon to gardeners. It is a specially treated meal, very attractive to snails as food and having the properties necessary for speedily killing them after they have eaten it One or two applications in the evening will completely e]iminate snails in the garden. Method of applying: After thoroughly wetting the premises, scatter SNAROL lightly over the wet ground. In the morning you will find numerous dead snails. Repeat this application after two weeks to destroy the young that have developed from eggs which might have been laid in the ground.

Do not place SNAROL within the reach of fovis. Prices:

1-1b. package $\ldots \ldots \ldots \ldots \ldots \ldots \ldots \ldots \ldots \ldots \ldots \ldots$

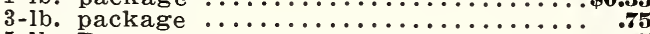

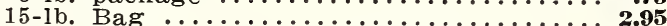

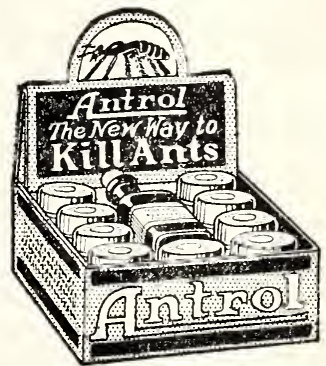

Is manufactured according to a United States Government formula.

The jars are of glass with aluminum top and should last a life time. The syrup can be purchased separately to refill the jars when they need replenishing.

Cottage sets containing 4 jars of ANTROL Syrup, shipping weight 2 lbs., 95c.

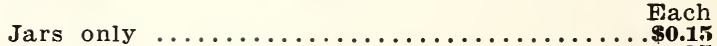

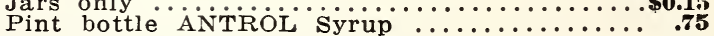
Quart bottle ANTROL Syrup ............. 1.25 ANTROL can NOT be mailed.

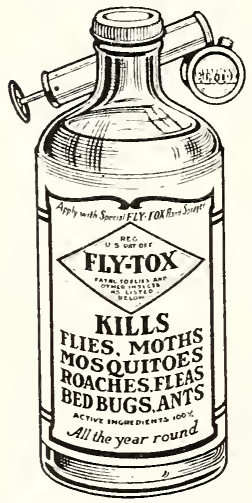

\section{FLIES ARE THE SCOURGE OF HUMANITY}

They have caused more deaths than all wars. Flies have been the source of endless numbers of painful, devastating sickness. They have crippled the body and im paired the mind of countless thousands. Flies are the enemies of mankind. They are filthy beyond human imagination. They taint everything they touch. The marks they leave by excretion and regurgitation are reeking pools of bacteria-wet, mucky matter swimming with disease germs.

Nothing is more repulsive, more foul than the fly. Nothing so threatens human life, health and happiness. No other thing can cause more suffering, sickness and death.

To enumerate and record those diseases carried by flies would fill several pages. Many animal organisms live in the flies alimentary canal. These are dropped in the excreta of the fly.

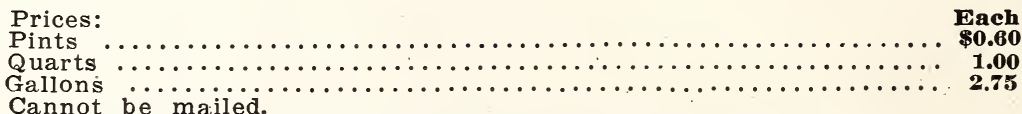

Cannot be mailed. 


\section{Sprays for Every Purpose \\ BUCKET PUMP \\ COMPRESSED AIR SPRAYER}

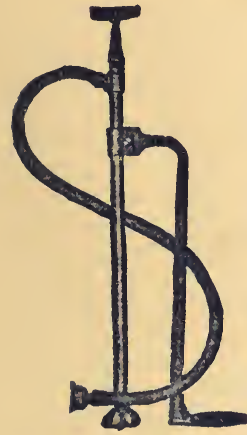

A bucket pump that is without a doubt the best bucket pump ever offered for sale. It is light. strong, reliable and will last a lifetime.

It is used by poultry-raisers, truck gardeners and by home gardeners throughout the country.

Double-acting.

All the working parts are brass, not subject to corrosion.

Bronze ball valves. Suited to any use where a pump of this kind is required.

\section{Price $\$ 5.00$}

SPRAIS CONTINUOUSLI

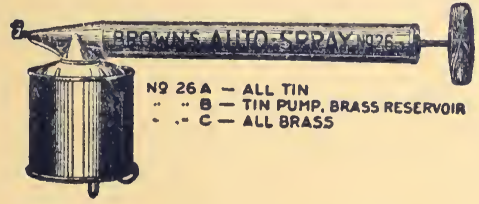

Uses: This sprayer is designed for spraying garden crops, for use in greenhouses, for handling disinfectants and fly oils. In fact, it can be used with almost all spraying solutions.

Auto-Spray No. 26 is manufactured with either a brass or a tin reservoir, as listed below:

Auto-Spray No. 26-A, 1 qt., all tin..........81.00

Auto-suray No. 26-C, 1 qt., brass pump. brass

tank

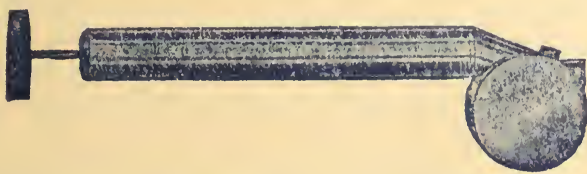

Auto-Spray No. 22.-For all kinds of small spraying and disinfecting. This atomizer is made of heavy tin and holds one quart. It is a single acting atomizer that throws a fine misty spray. This pump is fitted with an oil treated leather cup that lasts more than one season. Price, 60c.

\section{it's Double Acting}

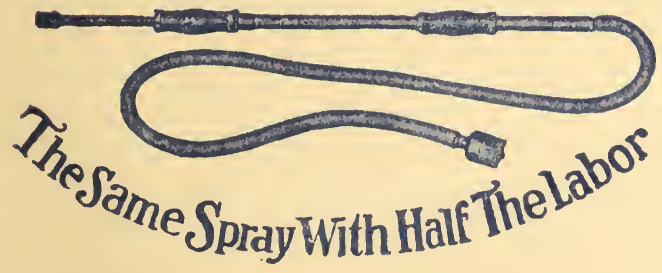

The Double Action High-Pressure Sprayer Use with any pail or bucket

AUTO SPRAY No. 5 is generally acknowledged to be the most powerful of this type manufactured, generates a pressure of 200 lbs. with remarkable ease. Throws continuous sprays on both the up and down strokes and requires about one half the energy of other pumps of this type. Suction end containing strainer, is weighted and will not work out of bucket.

Specifications-Solid brass throughout.

Shipping Weight -4 lbs.

Price \$5.00, f. o. b. Stockton.
Where there are fruit trees or largeshade $\mathrm{t} r \mathrm{e} e \mathrm{~s} \mathrm{th}$ is pump is very satisfactory than the Junior for it not on ly carries $m$ or e liquid b u t because of its larger $\mathrm{size}$ greater pressure may be obtained. Every one should give more time and attention to spraying the trees, shrubs and garden in general, for it is quite necessary to is quite insect pests and control insect pests and plants are to thrive. We consider that it would be far better to economize in other things if necessary to have a first class spray pump that class spray pump that than it is to have a

large garden of trees and plants and neglect them or only spray them partially with the smaller hand sprayer. No matter how small the garden an investment in spray pumps and spray materials means more fruit, better fruit, better trees, shrubs and flowers. The No. 9-D is equipped with hose, short extension rod and nozzle. The capacity is $31 / 2$ gallons, the tank is galvanized iron. Price $\mathbf{\$ 7 . 0 0}$ f. o. b. Stockton. Shipping weight $11 \frac{1}{2} \mathrm{lbs}$. No. 9-B Brass Tank, Price \$9.00.

\section{COMPRESSED AIR SPRAYER}

\section{No. 50-1 JUNIOI}

We believe that the No. 50-D Junior is one of the best values we have found. All working is $2 \frac{1}{2}$ gallons, it is equipped with hose and a short extension rod, and is very well made. Properly taken care of it will outlast inany of the little tin sprayers and besides making the spraying * pleasure it will do the job effectively and better fruits or plants will result. Shipping weight 7 lbs.

Galvanized Tank. Price \$5.00. Brass Tank, Price $\$ \mathbf{5 7 . 0 0}$

F. O. B. Stockton

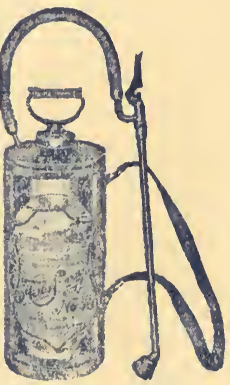

DUSTER BROWN No. 1

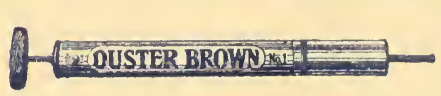

Duster Brown No. 1 is adapter for use with sulphur and all insect powders. Because of its size and efficiency it is a favorite with the housewife in applying roach, ant and various bug powders. Also very practical for dusting rose bushes, etc., in small gardens. This little gun makes dusting a pleasure. Price 50c. By mail (Boc.

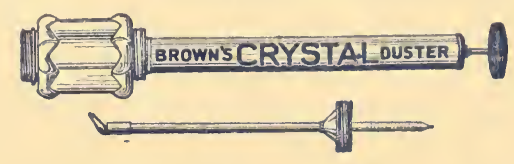

IBIROUNA'S CIRYSTAY, DUSTIEIR

Brown's Crystal Duster is one of the newest type duster's on the market. This duster has the glass jar feature which enables the operator to see the agitation of the dust and show the amount of dust in the container. It is equipped with a long extension and adjustable nozzle which enables the operator to dust from underneath without bendins. IBrown's Crystal buster, tin cylinder, ghlass contancr, 1 qt.., \$1.:30; postage 100. 


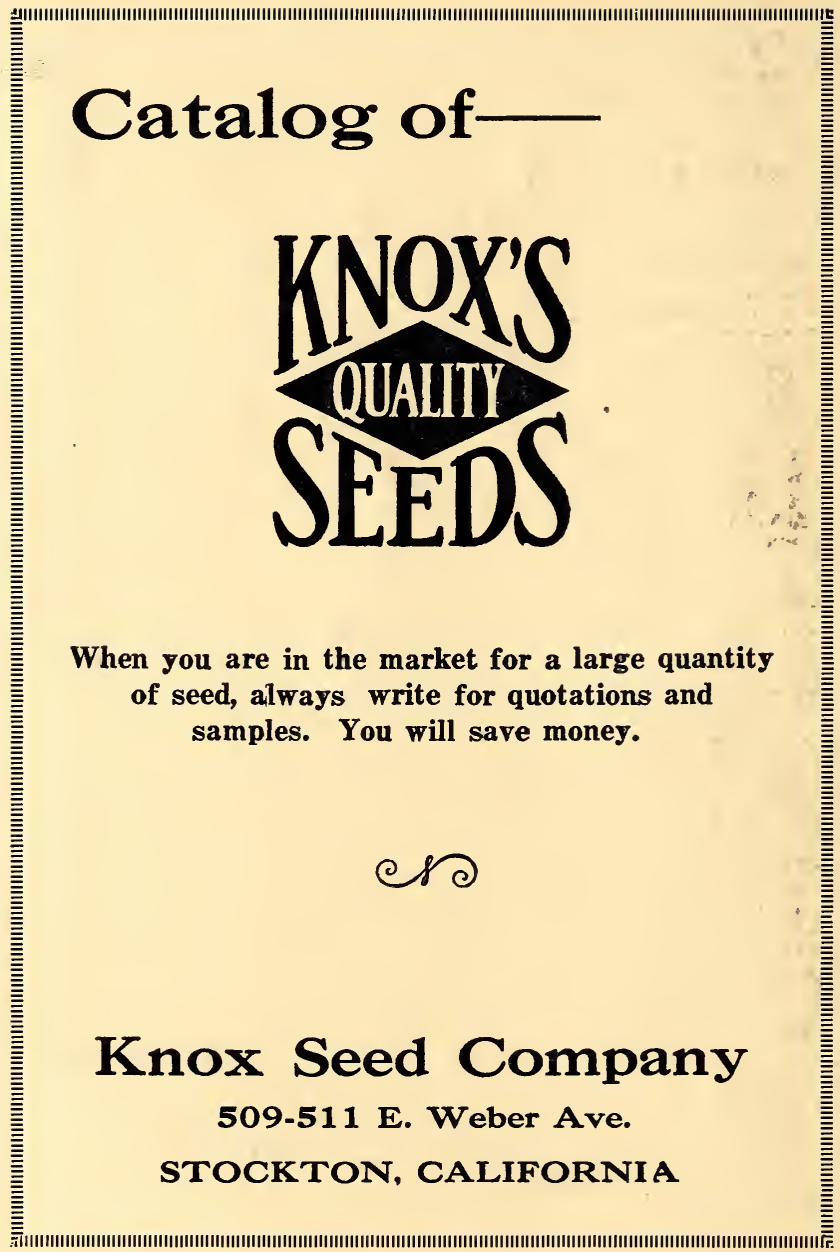

